Universidade de São Paulo

Faculdade de Saúde Pública

\title{
Alimentação complementar e estado nutricional de crianças menores de dois anos em Acrelândia, Acre, Amazônia Ocidental Brasileira.
}

\author{
Mariana Tarricone Garcia
}

Dissertação apresentada ao Programa de Pós Graduação em Nutrição em Saúde Pública para Obtenção do Título de Mestre em Ciências, Área Nutrição em Saúde Pública.

Orientadora: Profa. Dra. Marly Augusto Cardoso

São Paulo - SP

2009 
Alimentação complementar e estado nutricional de crianças menores de
dois anos em Acrelândia, Acre, Amazônia Ocidental Brasileira.

\section{Mariana Tarricone Garcia}

Dissertação apresentada ao Programa de Pós Graduação em Nutrição em Saúde Pública da Faculdade de Saúde Pública da Universidade de São Paulo para Obtenção do Título de Mestre em Ciências, Área Nutrição em Saúde Pública.

Orientadora: Profa. Dra. Marly Augusto Cardoso

São Paulo - SP

2009 
É expressamente proibida a comercialização deste documento, tanto na sua forma impressa como eletrônica. Sua reprodução total ou parcial é permitida exclusivamente para fins acadêmicos e científicos, desde que na reprodução figure a identificação do autor, título, instituição e ano da tese/dissertação. 


\section{AGRADECIMENTOS}

Agradeço a todos que me deram força, colo e que, principalmente, acreditaram que esta seria uma etapa importante de minha trajetória.

Agradecimentos especiais:

Ao meu pai, pela serenidade, compreensão e apoio.

Ao André, pelo carinho e amor revitalizantes.

À Marly, pela sabedoria, paciência e confiança.

À tia Dayse, por me ensinar a ver a vida com mais simplicidade.

Às minhas avós, pelo orgulho que sentem de mim a cada passo que dou.

À Lana, pelas risadas e digressões produtivas.

À Aline (Fível), pelas injeções de ânimo e amizade.

À Fernanda S. Granado, pelos ouvidos e companheirismo.

À Bruna e Juliana, pelos sonhos compartilhados e lealdade.

A toda equipe que participou do trabalho de campo em Acrelândia com muito bom humor e pouco sono.

Aos agentes comunitários de saúde, auxiliares de enfermagem e enfermeiras que colaboraram com a coleta dos dados com tanto entusiasmo.

Aos participantes deste estudo, tão receptivos e simpáticos.

À equipe que participou da digitação dos dados e análise bioquímica. 


\section{EPÍGRAFE}

"É fundamental diminuir a distância entre o que se diz e o que se faz, de tal forma que, num dado momento, a tua fala seja a tua prática."

Paulo Freire 
Garcia, MT. Alimentação complementar e estado nutricional de crianças menores de dois anos em Acrelândia, Acre, Amazônia Ocidental Brasileira. [dissertação de mestrado] São Paulo: Faculdade de Saúde Pública da Universidade de São Paulo; 2009.

\section{Resumo}

Objetivo: Investigar o estado nutricional, consumo alimentar e práticas de alimentação complementar em crianças de 6 a 24 meses residentes em Acrelândia, Estado do Acre, Amazônia Ocidental Brasileira.

Métodos: Estudo transversal de base populacional realizado na área urbana do município de Acrelândia. Informações sobre condições sociodemográficas, morbidades e aleitamento materno foram obtidas por questionário estruturado. A partir de dados de histórico alimentar, consumo e práticas alimentares foram analisados. Peso e comprimento foram medidos para avaliação antropométrica segundo distribuição da curva padrão da Organização Mundial da Saúde (OMS) 2007. Amostras de fezes foram obtidas para exame parasitológico. Avaliação das concentrações de hemoglobina, ferritina, receptor solúvel de transferrina, vitamina $B_{12}$, retinol e ácido fólico séricos foi realizada em amostras de sangue venoso coletadas em jejum.

Resultados: Do total de 166 crianças estudadas, as prevalências de déficit de estatura/idade e de anemia foram de $12 \%$ e $40 \%$, respectivamente. Dentre as crianças anêmicas, 95\% apresentaram anemia ferropriva. A prevalência geral de deficiência de ferro isolada foi $44 \%$. A presença de parasitas intestinais foi identificada em $26 \%$ das amostras de fezes, sendo que $80 \%$ das infecções foram causadas por Giardia lamblia. Os níveis séricos das vitaminas A e $\mathrm{B}_{12}$ estavam abaixo da faixa de normalidade em $15 \%$ e $12 \%$ das crianças, respectivamente. 0 aleitamento materno foi iniciado por quase a totalidade das mães (99\%); no entanto, a prática do aleitamento materno exclusivo até o sexto mês foi referida por $10 \%$ dos participantes. A oferta de leite de vaca foi alta desde os primeiros meses de vida, sendo que dos 6 aos 8 meses de idade $70 \%$ das crianças estudadas já ingeriam este alimento. A frequência de consumo de mingau aumentou com a idade: $37 \%$ das crianças entre 6 e 8 meses, $48 \%$ entre 9 e 11 meses e $64 \%$ entre 12 e 24 meses referiram seu consumo habitual. Consumo alimentar abaixo das recomendações da OMS (2004) foi observado para os seguintes nutrientes (\% de crianças): ácido fólico (33\%), vitamina C (40\%), vitamina A (42\%), zinco (46\%) e ferro (71\%). A biodisponibilidade de ferro da dieta ficou em torno de $8 \%$, classificando $78 \%$ das crianças com dietas entre "muito baixa" e "baixa" biodisponibilidade. Os alimentos que mais contribuíram com a energia total ingerida foram os leites de vaca e leite materno, e com o aporte de ferro foram os espessantes utilizados para fazer mingau.

Conclusão: Os resultados sugerem intervenções para a promoção do aleitamento materno exclusivo até o sexto mês, com introdução de alimentos e práticas de alimentação complementar adequadas. É essencial melhorar a biodisponibilidade do ferro da dieta através do maior consumo de ferro total (carnes, feijão e caldos de carnes/feijão) e de vitamina C (incentivo ao consumo de frutas e hortaliças) desde 0 início da alimentação complementar, evitando-se consumo de alimentos ricos em compostos inibidores da absorção do ferro, tais como café, chá, espessantes e leite 
de vaca. Com o aumento da idade da criança, o consumo de mingau deve ser gradualmente substituído, incentivando-se consumo de alimentos disponíveis para a família.

Descritores: alimentação complementar; estado nutricional; consumo alimentar; anemia ferropriva; nutrição infantil; saúde infantil. 
Garcia, MT. Complementary feeding and nutritional status of 6-24-monthold children from Acrelândia, Acre, Westhern Brazilian Amazon. [Master thesis] São Paulo: Faculdade de Saúde Pública da Universidade de São Paulo; 2009.

\begin{abstract}
Objective: To investigate the nutritional status, food consumption and complementary feeding practices in children aged between 6 and 24 months living in Acrelândia, Acre State, Westhern Brazilian Amazon.

Methods: A population-based, cross-sectional study was conducted within an urban area of Acrelândia. Information on sociodemographic conditions, morbidity and breast feeding were collected using structured questionnaires. Food consumption and practices were analyzed based on food history data. Anthropometric assessment entailed weight and height measurements according to the 2007 World Health Organization (WHO) standard distribution curve. Stool samples were obtained and subjected to parasitological examination. Assessment of hemoglobin, ferritin, soluble transferrin receptor, Vitamin $B_{12}$ and retinol serum levels was performed on fasting venous blood samples.
\end{abstract}

Results: Of the total 166 children studied, the prevalence of stunted height/age and anemia was $12 \%$ and $40 \%$, respectively. Out of the anemic children, $95 \%$ presented with iron-deficient anemia. The overall prevalence of iron deficiency was $44 \%$. Intestinal parasites were detected in $26 \%$ of the stool samples, where $80 \%$ of these infections were caused by Giardia lamblia. Vitamin $A$ and $B_{12}$ serum levels were below normal thresh holds in $15 \%$ and $12 \%$ of children, respectively. Breast feeding was started by the vast majority of mothers (99\%) although exclusive breast feeding up to the sixth month was reported by only $10 \%$ of participants. The intake of cow's milk was high from the first months of life, where $70 \%$ of the children studied were consuming cow's milk at 8 months of age. The frequency of porridge (cow's milk and maize flour) consumption increased with age: $37 \%$ of the children aged between 6 and 8 months, 48\% between 9 and 11 months and 64\% between 12 and 24 months, reported regular porridge consumption. Food consumption at levels below WHO recommendations (2004) were observed for the following nutrients (\% of children): folic acid (33\%), Vitamin C (40\%), Vitamin A $(42 \%)$, zinc $(46 \%)$ and iron $(71 \%)$. The bioavailability of iron in the diet was approximately $8 \%$, with $78 \%$ of the children's diets being classified as having "low" or "very low" bioavailability. The foods which contributed most to total energy ingested were cow's milk and mother's breast milk, and in terms of iron, were the thickening agents used in porridge making.

Conclusion: These results suggest that interventions should be introduced to promote exclusive breast feeding up to the sixth month, along with the introduction of healthy complementary foods and feeding practices. Improvements in bioavailability of iron in the diet are essential, through higher total iron consumption (meat, beans and meat/bean stock) and Vitamin C (encouragement to consume more fruit and vegetables) from the outset of introducing complementary food, while consumption of foods rich in iron inhibitors such as coffee, tea, thickeners and cow's milk should be avoided. As child age increases, porridge consumption should be gradually substituted by encouraging the consumption of alternative foods available to the family. 
Descriptors: complementary feeding; nutritional status; food intake; iron deficiency anemia; child nutrition; child health. 


\section{ÍNDICE}

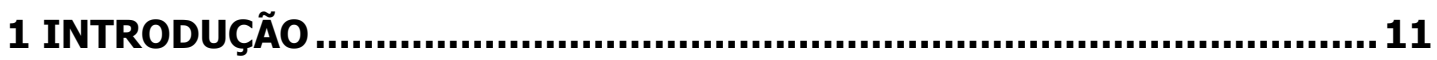

1.1 ESTADO NUTRICIONAL NOS PRIMEIROS 2 ANOS DE VIDA ......................12

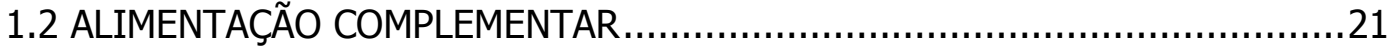

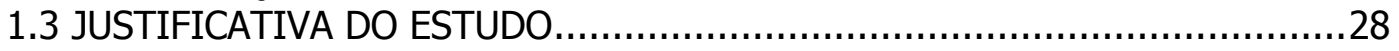

2 OBJETIVO

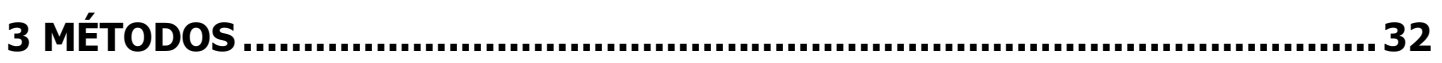

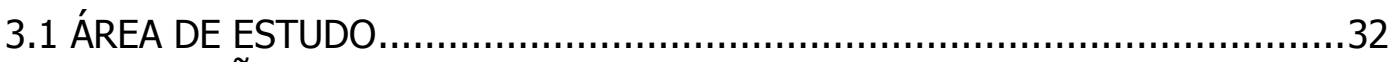

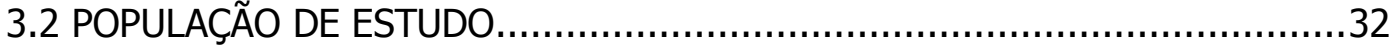

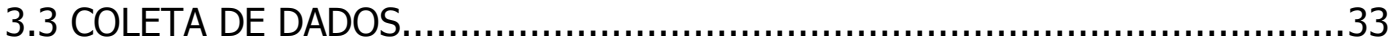

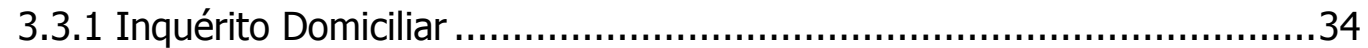

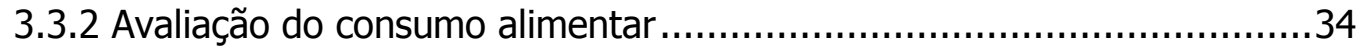

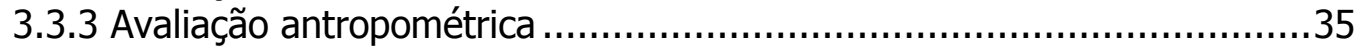

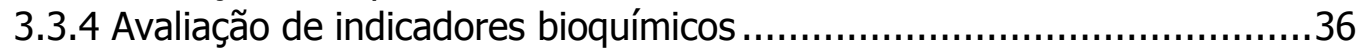

3.3.5 Exame parasitológico de fezes ....................................................38

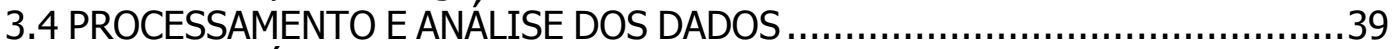

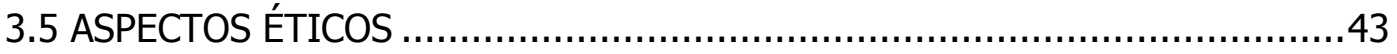

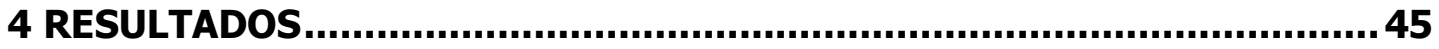

4.1 CARACTERIZAÇÃO DA POPULAÇÃO DE ESTUDO …................................45

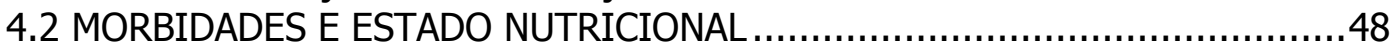

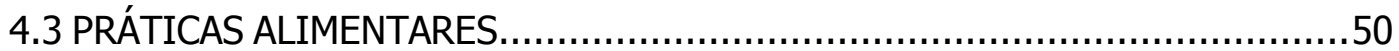

4.4 AVALIAÇÃO DO CONSUMO ALIMENTAR ........................................55

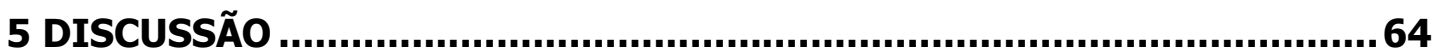

5.1 CARACTERIZAÇÃO DA POPULAÇÃO DE ESTUDO …............................65

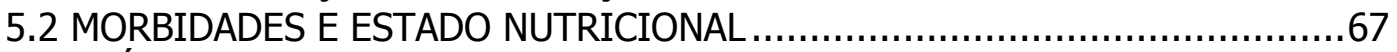

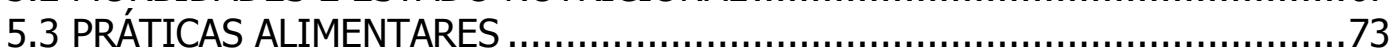

5.4 AVALIAÇÃO DO CONSUMO ALIMENTAR ........................................ 80

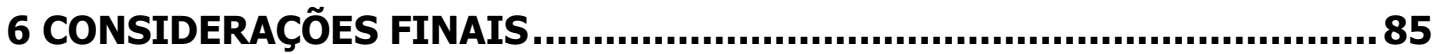

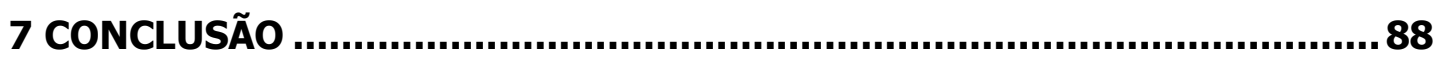

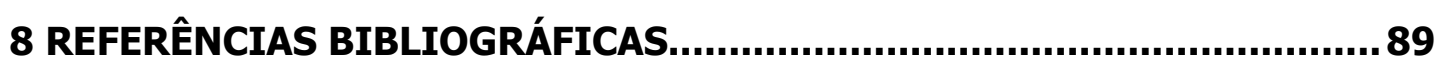

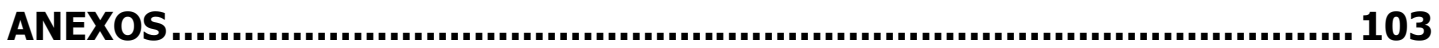




\section{INTRODUÇÃO}

Especialmente os dois primeiros anos de vida da criança são caracterizados por crescimento acelerado e enormes aquisições no processo de desenvolvimento. Neste período, a criança deve aumentar o peso em quase 4 vezes e praticamente dobrar o comprimento (WHO 2006). O desenvolvimento ocorre em vários domínios vitais e interdependentes, incluindo sensitivo-motor, cognitivo e socioemocional (GRANTHAM-MCGREGOR e col 2007).

O estado nutricional infantil é determinado pelo consumo alimentar e pelo estado de saúde da criança. Estes, por sua vez, são modulados pela disponibilidade de alimentos no domićlio, salubridade do ambiente e adequação dos cuidados dispensados à criança. Mas estes fatores, por sua vez, são também influenciados pelo nível de renda familiar, oferta de serviços públicos de saúde, saneamento, educação e programas governamentais (MONTEIRO e col 1993).

Os dois primeiros anos de vida representam um período crítico de vulnerabilidade aos agravos sociais, econômicos e ambientais (OLIVEIRA e col 2006). Em um recente estudo de revisão, KREBS e HAMBIDGE (2007) reconhecem que $50 \%$ da mortalidade infantil é direta ou indiretamente relacionada à desnutrição.

Deficiências nutricionais ou condutas inadequadas quanto à prática alimentar podem influenciar os riscos de morbimortalidade, 0 crescimento e 0 desenvolvimento infantis (MONTEIRO e col 1993).

A nutrição apropriada durante a primeira infância é fundamental para se desenvolver todo o potencial humano. A alimentação complementar, segura e 
adequada para crianças amamentadas, é reconhecida como fator imprescindível na prevenção da desnutrição infantil (DEWEY 2001).

\subsection{ESTADO NUTRICIONAL NOS PRIMEIROS 2 ANOS DE VIDA}

Segundo o UNICEF (2007), morrem diariamente mais de 26 mil crianças menores de 5 anos de idade em todas as partes do mundo, mas principalmente em países em desenvolvimento e por causas evitáveis. Dessas mortes, 73\% são atribuídas a 6 causas: pneumonia (19\%), diarréia (18\%), malária (8\%), sepsis ou pneumonia neonatal $(10 \%)$, nascimento pré-termo (10\%) e asfixia no nascimento (BRYCE e col 2005).

As causas primárias e subjacentes das mortes de crianças menores de 5 anos são: desnutrição, serviços de saúde e nutrição carentes de recursos, ineficazes e culturalmente inadequados; insegurança alimentar; práticas alimentares inadequadas; analfabetismo da mulher; gravidez precoce; discriminação e exclusão de mães e crianças do acesso a serviços e instalações essenciais nas áreas de saúde e nutrição; falta de higiene e de acesso à água limpa ou a condições de saneamento adequadas (UNICEF 2007).

Nos países em desenvolvimento, uma em cada cinco pessoas não usa água limpa e, aproximadamente, metade da população não dispõe de condições de saneamento adequadas (UNICEF 2007). Estima-se que quase dois milhões de crianças menores de 5 anos de idade morrem a cada ano devido à diarréia (WHO 2008). As doenças diarréicas ainda são consideradas um dos principais problemas que afetam as crianças nos países em desenvolvimento; no entanto, a mortalidade infantil por esta causa vem declinando no Brasil (BENÍCIO e MONTEIRO 2000). 
De fato, na última Pesquisa Nacional de Demografia e Saúde (PNDS) realizada em 2006 constatou-se redução significativa da mortalidade de menores de 5 anos por causas infecciosas e parasitárias, incluindo aquelas associadas à síndrome diarréica. A prevalência de crianças que apresentaram diarréia nos últimos 15 dias anteriores à pesquisa foi de $9,4 \%$ no Brasil e a região Norte apresentou a maior prevalência: 14,6\%. Também foi evidenciado que o período entre 6 e 23 meses é aquele em que esta prevalência se mostrou maior (MS 2008).

Quando uma criança contrai diarréia, há mais probabilidade de ficar desnutrida. Assim, com resposta imune comprometida, a criança fica mais susceptível a contrair a mesma doença, gerando um ciclo de alto risco e difícil de ser rompido (UNICEF 2006). Desnutrição e infecções recorrentes em geral estão associadas.

A desnutrição nos primeiros anos de vida é um dos maiores problemas de saúde enfrentados por países em desenvolvimento. Déficits de crescimento na infância se associam à maior mortalidade, excesso de doenças infecciosas, prejuízo para o desenvolvimento psicomotor, menor aproveitamento escolar e menor capacidade produtiva na idade adulta (BLACK e col 2008, VICTORA e col 2008).

Em recente estudo de revisão, BLACK e col (2008) afirmam que, em 2005, $20 \%$ das crianças menores de 5 anos em países em desenvolvimento tinham escore-Z de peso/idade menores de -2 ; já a prevalência de stunting foi de $32 \%$, ou seja, 178 milhões de crianças.

No Brasil, segundo a última PNDS, a prevalência de déficits de altura-paraidade entre as crianças brasileiras menores de 5 anos de idade foi de $7 \%$. Essa frequência vai de $4,9 \%$ no primeiro ano de vida para $12,3 \%$ no segundo, quando 
alcança seu pico, reduzindo-se progressivamente nas idades posteriores. O retardo de crescimento na infância é acentuadamente mais frequente na região Norte $(14,9 \%)$ do que nas demais regiões do País. Déficits de peso-para-altura não ultrapassaram 3\% em qualquer estrato da população, indicando um equilíbrio adequado entre o acúmulo de massa corporal e o crescimento linear das crianças. A frequência de déficits de peso-para-idade entre as crianças menores de 5 anos de idade foi de $1,7 \%$, ficando entre $1 \%$ e $3 \%$ na grande maioria dos demais estratos estudados (MS 2008).

Comparando-se os resultados da PNDS de 1996 com os da PNDS de 2006, observa-se que houve redução de cerca de $50 \%$ na prevalência da desnutrição infantil entre 1996 e 2006. Dois terços dessa redução foram atribuídos a melhores condições de escolaridade das mães, do poder aquisitivo das famílias (sobretudo das mais pobres), do acesso à assistência à saúde e das condições do saneamento (MONTEIRO e col 2009).

No entanto, BATISTA-FILHO e RISSIN (2003) afirmaram que o declínio da desnutrição no Brasil não tem sido acompanhado por evolução favorável na ocorrência da anemia, pelo contrário, há tendência temporal de aumento da prevalência da anemia nas crianças menores de cinco anos. Os autores observaram que não existem diferenças marcantes na ocorrência de anemia entre diversas microrregiões do país; assim, o problema afeta ricos e pobres.

A carência de ferro é um grande problema de saúde pública, atingindo tanto países em desenvolvimento como os desenvolvidos (WHO 2008b). A anemia resultante da deficiência grave de ferro é o problema nutricional em crianças pequenas mais prevalente e difundido nos países em desenvolvimento (INACG 2000). 
A Organização Mundial da Saúde (OMS) estima que metade de todos os casos de anemia seja devido à deficiência de ferro, e que a prevalência de deficiência de ferro nos países em desenvolvimento seja 2,5 vezes maior que a de anemia (WHO 2001).

A deficiência de ferro no primeiro ano de vida tem consequências preocupantes, pois este é um período marcado por desenvolvimento neurológico rápido, portanto, alterações morfológicas, bioquímicas e bioenergéticas podem influenciar o desenvolvimento futuro (RAO e GEORGIEFF 2007; LOZOFF e col 2006). O ferro é necessário para a neurogênese e para a diferenciação de certas células e regiões cerebrais (RAO e GIORGIEFF 2007; WARD e col 2007; RAO e col 2003). Assim, as estruturas cerebrais podem ter desenvolvimento anormal devido à deficiência de ferro intra-uterina ou no início da vida pós-natal. Os sintomas mais comuns da deficiência de ferro neste grupo incluem: comprometimento do desenvolvimento mental, dificuldades no crescimento e desenvolvimento físico, reduzida atividade física e produtividade, aumento na frequência de morbidades, dentre outros (GILLESPIE 1998).

Em muitos países a prevalência de anemia $(\mathrm{Hb}<11,0 \mathrm{~g} / \mathrm{L})$ entre os 6 e 9 meses é alarmantemente alta: $64 \%$ a $93 \%$ na África Subsaariana, $70 \%$ a $85 \%$ no Sudeste Asiático e 59\% a 75\% na América Latina e Caribe (CHAPARRO 2008).

Embora inquéritos nacionais de base populacional sejam escassos no Brasil, o MINISTÉRIO DA SAÚDE (MS 2008b) estima que a prevalência de anemia entre crianças menores de cinco anos varie de 30 a $70 \%$, sendo que as maiores prevalências (> 50\%) são observadas nas crianças com idade abaixo de 24 meses. De fato, dos 6 aos 18 meses, as necessidades de ferro tendem a ser maiores que a ingestão (BEARD 2008). 
Nos primeiros meses de vida a criança se adapta ao ambiente extra-uterino e ocorrem mudanças na dinâmica hematológica. A alta concentração de hemoglobina encontrada no nascimento não é mais necessária e a produção de células vermelhas se lentifica em resposta à maior disponibilidade de oxigênio no ambiente. Além do tempo de vida das células vermelhas fetais ser menor, estes dois fatores resultam na diminuição da concentração de hemoglobina. O ferro heme reciclado do envelhecimento das células vermelhas é estocado na forma de ferritina. Então, os estoques de ferro presentes no nascimento e o ferro heme acrescentado aos estoques durante o período de adaptação irão formar a principal fonte de ferro nos primeiros meses de vida (CHAPARRO 2008).

Sabe-se que o estoque de ferro no nascimento é uma peça-chave na determinação dos fatores de risco para anemia infantil, devido à baixa concentração de ferro no leite humano (WHO 2001). Os estoques de ferro em crianças exclusivamente amamentadas com leite materno do nascimento aos seis meses de vida atingem as necessidades fisiológicas infantis, eliminando, portanto, a necessidade de suplementação ou introdução de alimentos sólidos neste período (DOMELLOF e col 2001; DEWEY e col 1998). Isso se deve à alta biodisponibilidade do ferro no leite humano, que é de aproximadamente $50 \%$ do ferro total, o que compensa sua baixa concentração. Entretanto, essa biodisponibilidade pode cair $80 \%$ quando outros alimentos são ingeridos pela criança (INSTITUTE OF MEDICINE 2000).

No entanto, o estado nutricional materno pode afetar tanto as reservas nutricionais da criança no nascimento como também a composição do leite materno. Em geral, a dieta materna pode influenciar o conteúdo de vitaminas do leite materno, mas tem menos impacto no conteúdo de minerais (KREBS 2007). 
Do quarto ao sexto mês de vida, os estoques de ferro são gradualmente depletados. No período compreendido entre 6 e 12 meses de idade, há aumento da ordem de $50 \%$ a $70 \%$ das necessidades de ferro para prover o crescimento de tecidos e a alimentação, então, atua com papel predominante no alcance das necessidades deste mineral (GILLESPIE 1998).

Em estudo transversal com 181 crianças de 4 a 18 meses do Reino Unido, WHARF e col (1997) relataram que aos 4 meses de idade os estoques de ferro estavam associados ao peso ao nascer e ao peso atual da criança, enquanto que, aos 8 meses, os fatores dietéticos se tornaram mais importantes. Aos 12 meses de idade, as meninas apresentaram maiores níveis de ferritina plasmática que os meninos. Já aos 18 meses, o consumo de ferro não heme teve associação negativa com a concentração de ferritina plasmática, refletindo a baixa biodisponibilidade do ferro não heme e o efeito dos fatores inibidores presentes nos alimentos altos em ferro não heme.

No Brasil, OSÓRIO e col (2004) realizaram estudo transversal com amostra representativa de crianças de 6 a 59 meses do estado de Pernambuco e encontraram que, de forma geral, a ingestão de ferro era inadequada, sendo que a faixa etária com maior inadequação foi de 6 a 11 meses. Em relação à concentração de hemoglobina, a média entre as crianças de 6 a 23 meses foi de 10,0 g/L sendo que as crianças de 6 a 11 meses apresentaram os piores valores. Foi observada associação positiva entre a biodisponibilidade de ferro da dieta e concentração de hemoglobina. Presença de rede de esgoto e tratamento de água foram associadas com maiores concentrações sanguíneas de hemoglobina, enquanto ter apresentado diarréia nos últimos 15 dias mostrou associação negativa com os níveis de hemoglobina. 
NEUMAN e col (2000) realizaram estudo transversal de base populacional em Criciúma (SC) com 476 crianças menores de 3 anos. A prevalência de anemia foi de $54 \%$, sendo que a maior prevalência foi na faixa de 12 a 18 meses. Os autores ressaltam que Criciúma está entre os 50 melhores municípios do Brasil de acordo com o índice de sobrevivência de crianças (UNICEF/IBGE 1994), o que não resultou em menor prevalência de anemia entre as crianças deste município. Foram encontrados como fatores de risco para anemia [categoria da variável (valor do odds ratio ajustado; valores do intervalo de confiança de 95\%]: idade da criança entre 12 e 18 meses (ORaj=5,82; IC95\%=2,69 - 12,60), renda familiar entre $\mathrm{R} \$ 301,00$ e $\mathrm{R} \$ 480,00$ (ORaj=0,82; IC95\%=0,68 - 0,99), 3,1 ou mais moradores dividindo a mesma peça utilizada para dormir (ORaj=3,05; IC95\%=1,06 - 8,74) e sanitário sem descarga (ORaj=1,78; IC95\%=0,91 - 3,45).

SPINELLI e col (2005) realizaram estudo transversal em 12 municípios das 5 regiões do Brasil com 2715 crianças de 6 a 12 meses e encontraram alta prevalência de anemia em todos os locais, definida pela concentração de hemoglobina abaixo de $11 \mathrm{~g} / \mathrm{dL}$. Associações positivas foram observadas entre anemia e idade materna menor que 20 anos, baixo peso ao nascer e sexo masculino. $O$ escore $Z$ de peso para idade menor que -1 foi considerado fator de risco para anemia e o consumo de carne, fator de proteção.

Em São Leopoldo (RS) foi realizado estudo de intervenção com 369 crianças acompanhadas no $1^{\circ}$ ano de vida com orientações nutricionais mensais em visitas domiciliares. Aos 12 meses de idade foi realizado inquérito recordatório do consumo alimentar de 24 horas. Observou-se que as crianças não anêmicas tiveram ingestão de ferro e de vitamina C significativamente maior que as anêmicas e maior proporção de crianças com dieta de alta biodisponibilidade de ferro, definida pela 
ingestão de quantidades maiores que $70 \mathrm{~g}$ de carne e que $25 \mathrm{mg}$ de vitamina $\mathrm{C}$. Foram encontrados como fatores de proteção para anemia a menor ingestão de leite de vaca e de cálcio e a maior ingestão calórica no jantar (VITOLO e BORTOLINI 2007).

Em outros países, resultados semelhantes têm sido encontrados. No México, RODRIGUEZ e col (2007) realizaram estudo transversal com 919 crianças de 12 a 59 meses. O consumo de ferro total não se associou com a hemoglobina sanguínea. Encontraram associação positiva entre a biodisponibilidade de ferro na dieta e o nível de hemoglobina, principalmente entre as crianças de 12 a 23 meses, e associação negativa entre consumo de leite de vaca maior que $600 \mathrm{ml} / \mathrm{dia}$ e hemoglobina. Os autores concluem que se o consumo de ferro biodisponível fosse dobrado ocorreria um aumento de $0,41 \mathrm{~g} / \mathrm{dL}$ nos níveis de hemoglobina.

Além do conteúdo de ferro nos alimentos, também é importante investigar o quanto do ferro ingerido é biodisponível. Segundo a OMS, (WHO 1989; 1998) dietas com baixa biodisponibilidade de ferro são, em geral, monótonas, constituídas principalmente de cereais que inibem a absorção de ferro (como milho e trigo integral), legumes, raízes e/ou tubérculos, com pouca quantidade de carne e peixe ou vitamina C. Dietas intermediárias consistem de cereais que inibem pouco a absorção de ferro e de raízes e ou tubérculos, com pouca quantidade de produtos animais ou vitamina C. A dieta com alta biodisponibilidade é diversificada e contêm quantidades generosas de carne, peixe e aves e alimentos ricos em vitamina C.

A deficiência de ferro não é a única causa de anemia. A hipovitaminose A é provavelmente a segunda maior causa subjacente, enquanto que as deficiências de ácido fólico e vitamina $B_{12}$ também podem causar anemia (WHO 2007). 
As deficiências de vitamina $B_{12}$ e de ácido fólico comprometem a manutenção da biossíntese de purina e pirimidina. A redução na capacidade de sintetizar DNA e manter a divisão celular é mais claramente vista na síntese dos eritrócitos, o que resulta na anemia megaloblástica, uma anemia macrocítica (KRAEMER e ZIMMERMANN 2007).

O déficit na ingestão é a causa mais comum na deficiência de ácido fólico. 0 ácido fólico na natureza é instável, não totalmente biodisponível e não é encontrado em grande densidade em nenhum alimento, exceto no fígado, que não faz parte da maioria das dietas. As hortaliças são boas fontes de ácido fólico, mas devido ao baixo consumo, principalmente nos países em desenvolvimento, se torna difícil garantir ingestão adequada (KRAEMER e ZIMMERMANN 2007).

Já a vitamina $B_{12}$ é abundante na maioria das dietas, uma vez que está presente nos alimentos de origem animal, principalmente em carnes, mas também em leites e ovos. A deficiência deste nutriente é prevalente nos países onde existe baixa ingestão dos alimentos ricos em vitamina $B_{12}$, devido à falta de acesso e ao alto custo. Os níveis de vitamina $B_{12}$ da mãe também são importantes para o conteúdo deste nutriente no leite materno, já que este alimento não é uma boa fonte da vitamina (KRAEMER e ZIMMERMANN 2007).

A deficiência de vitamina A pode aumentar o risco de deficiência de ferro para a eritropoiese e de anemia devido a alterações na absorção, estoque, liberação ou transporte de ferro para a medula. A vitamina A é conhecida por ter duas funções básicas: promover o funcionamento adequado dos fotorreceptores na retina para permitir uma boa visão em condições de pouca luz, e regular a síntese de proteínas que são relacionadas ao crescimento, diferenciação, função ou longevidade das células. Na deficiência deste nutriente pode ocorrer a xeroftalmia 
(cegueira noturna), com comprometimento da hematopoiese dos sistemas celulares epitelial, imune, ósseo e outros (KRAEMER e ZIMMERMANN 2007).

Devido ao papel da vitamina A na resposta imune adequada, sua deficiência também pode interferir no sequestro de ferro induzido pela inflamação e outras respostas à infecção que aumentam o risco de anemia. Intervenções que controlam a deficiência de vitamina A contribuem também no controle da anemia (KRAEMER e ZIMMERMANN 2007).

\subsection{ALIMENTAÇÃO COMPLEMENTAR}

O aleitamento materno é um dos principais instrumentos para a promoção da saúde infantil. Recomenda-se que durante os primeiros 6 meses de vida as crianças sejam amamentadas exclusivamente, ou seja, sem nenhuma complementação de outros líquidos ou alimentos (WHO 2001b). Isso protege contra mortalidade e morbidade por infecções e promove o crescimento e desenvolvimento adequados (KRAMER e KAKUMA 2004). Conhecimentos sobre os benefícios do aleitamento materno, principalmente o exclusivo, encontram-se bem difundidos na literatura.

Após os primeiros 6 meses de vida, o leite materno não é mais suficiente para suprir as necessidades nutricionais. Então, é necessário iniciar a alimentação complementar, com a manutenção do aleitamento materno até os 2 anos ou mais (PAHO/WHO 2004).

Desde a publicação do documento da Organização Mundial da Saúde de 1991 (WHO 1991), em que eram divulgados indicadores para avaliar as práticas alimentares infantis e o progresso dos esforços para a promoção do aleitamento 
materno, tem havido importantes evoluções nas recomendações e no conhecimento científico sobre alimentação de crianças pequenas (WHO 2008c).

Entende-se por alimentação complementar aquela que é oferecida no período em que outros líquidos e alimentos são ofertados à criança em adição ao leite materno. Já o alimento complementar é qualquer alimento oferecido durante o período de alimentação complementar que não seja o leite materno (WHO 1998). Para que a alimentação complementar seja considerada ótima ela deve ser: Oportuna, Adequada, Segura e Apropriadamente oferecida (WHO/UNICEF 2003).

A alimentação complementar oportuna é aquela que começa quando a energia e os nutrientes fornecidos pelo aleitamento materno exclusivo não são mais suficientes para atingir as necessidades da criança. Ser adequada significa fornecer energia, proteínas e micronutrientes suficientes para atingir as necessidades para o crescimento da criança. A segurança se refere às práticas que garantam a higiene na aquisição, no armazenamento e no preparo dos alimentos complementares, e sua oferta com as mãos e utensílios limpos e sem utilizar mamadeiras e bicos. A observação dos sinais de apetite e saciedade da criança e o método de alimentação que encoraje a criança a comer o suficiente para a idade compõem o oferecimento apropriado (WHO/UNICEF 2003).

Grande parte das crianças brasileiras inicia a amamentação. Segundo a última PNDS, 96,4\% das crianças menores de 60 meses foram alguma vez amamentadas (MS 2008). No entanto, a introdução de outros alimentos e bebidas é precoce, ocorrendo durante as primeiras semanas ou meses de vida. No Brasil, a duração mediana do aleitamento materno exclusivo é de 2,17 meses e 41,7\% das crianças brasileiras de 4 a 6 meses de idade já consomem leite não materno (MS 2008). 
Em Cuiabá (MT), BRUNKEN e col (2006) realizaram estudo transversal realizado durante Campanha Nacional de Vacinação com 921 crianças menores de 1 ano. Encontraram que 20\% ingeriam água e chá logo ao nascer e que aos 4 meses $70 \%$ ingeriam água e $40 \%$ chá.

Em outro estudo transversal, também conduzido durante campanha de vacinação, com 719 crianças menores de 1 ano de São José do Rio Preto (SP), foi encontrado que poucas crianças estavam em aleitamento materno exclusivo antes dos 6 meses. Apenas 36\% das crianças com até 30 dias de vida só se alimentavam de leite materno e somente $3 \%$ na faixa etária de 5 a 6 meses. As introduções de água, chá e leite de vaca se davam na idade mediana de 30 dias. Também observaram que a idade mediana de introdução de alimentos pastosos (papa de frutas e de legumes) era de 120 dias (FIGUEIREDO 2004).

VIEIRA e col (2004), em estudo transversal de base populacional com 2319 crianças menores de 1 ano de Feira de Santana (BA), encontraram diferenças significativas entre as práticas alimentares de crianças amamentadas e desmamadas. O consumo de alimentos sólidos e semi-sólidos no primeiro mês foi maior entre as crianças desmamadas e a prática do aleitamento materno esteve associada com melhores comportamentos alimentares no que se refere à época de introdução de alimentos. Entre as crianças com até 4 meses de idade não amamentadas houve maiores chances de receber refeição da família (IC95\% 3,2320,66) e papas de legumes (IC95\% 3,48-11,78) e a prevalência de crianças que receberam água, chás, sucos e papas de frutas foram significativamente maiores.

Mesmo com aleitamento materno bem estabelecido as crianças podem apresentar déficit de crescimento se não receberem alimentos complementares em 
quantidade e qualidade adequadas depois dos 6 meses de idade (BLACK e col 2008).

No Brasil, o processo de introdução de alimentos, em geral, não é oportuno nem adequado (MS 2002). Na última PNDS (MS 2008) pôde-se observar que o percentual de crianças de 0 a 6 meses que já estão em amamentação complementada é de $52 \%$, enquanto que $35,6 \%$ das crianças de 6 a 8 meses não haviam consumido nenhuma comida de sal nas últimas 24 horas anteriores à pesquisa.

Em estudo transversal realizado durante campanha de vacinação em 136 municípios do estado de São Paulo com 24448 crianças de 6 a 12 meses, foi observado que dos 6 aos 9 meses de idade $48 \%$ das crianças ainda não consumiam refeições de sal (SALDIVA e col 2007).

Inadequações no processo de alimentação complementar são comuns em diversos países, desenvolvidos ou em desenvolvimento. FEIN e col (2008) realizaram estudo transversal com 2400 crianças com idade até 12 meses dos Estados Unidos e encontraram que aproximadamente $20 \%$ das mães começaram a oferecer alimentos complementares antes dos 4 meses e que existia associação positiva entre escolaridade materna e práticas corretas de alimentação complementar.

Em estudo longitudinal na República Tcheca, KUDLOVA e RAMES (2007) acompanharam 97 crianças, coletando dados no nascimento e também aos 6, 9, 12 e 24 meses de idade. Entre 9 e 24 meses 23\% a 38\% das crianças não consumiam hortaliças diariamente e $28 \%$ a $40 \%$ não ingeriam carnes diariamente. 
HENDRICKS e col (2006), em estudo transversal com 2515 mães com filhos de 4 a 24 meses dos Estados Unidos, encontraram associações de melhores práticas alimentares (como iniciar o aleitamento materno, oferecimento de suco e momento de início da alimentação complementar adequado) com características maternas e da criança (como ter educação superior, ser casada, a criança frequentar creche, maior idade materna, maior renda e a criança ter sido amamentada).

COULTHARD e col (2009), em estudo de coorte que seguiu 7821 crianças inglesas dos 6 meses aos 7 anos de idade, revelaram que a idade de introdução de alimentos complementares semi-sólidos influencia a aceitação alimentar aos 7 anos. A introdução após os 10 meses pode levar a problemas em relação à alimentação, como não ingerir quantidade suficiente, ser muito seletivo com os tipos de alimentos, se recusar a comer, consumir menos porções de frutas e de hortaliças e também menor variedade de hortaliças.

Tanto a introdução tardia como a precoce têm sido consideradas prejudiciais à saúde das crianças. No Senegal 420 crianças foram acompanhadas dos 2 aos 10 meses e encontrou-se que as que receberam alimentos complementares muito cedo (de 2 a 3 meses) tiveram um estado nutricional significantemente menos adequado que as outras crianças, segundo os índices antropométricos estatura/idade, peso/idade, peso/estatura e o valor da circunferência do braço (SIMONDON e SIMONDON 1997).

KALANDA e col (2006), em estudo de coorte, analisaram 494 crianças do Malawi desde o nascimento até os 12 meses de idade. $\mathrm{O}$ analfabetismo materno se associou com a introdução precoce de alimentos complementares que, por sua vez, esteve significantemente associada com aumento do risco de infecções respiratória e ocular e de episódios de malária. 
Em estudo transversal de base populacional com crianças de 6 a 24 meses residentes em 4 comunidades rurais do Malawi, HOTZ e GIBSON (2001) também observaram a introdução precoce de alimentos complementares. A faixa etária de 6 a 8 meses apresentou os maiores déficits de consumo de nutrientes. Em relação à densidade nutricional dos alimentos notou-se que ferro, cálcio e zinco foram os micronutrientes com menores densidades.

Um dos determinantes da ingestão alimentar nesta faixa etária é a consistência dos alimentos oferecidos. Alimentos menos consistentes que o recomendado podem ter baixas densidades energética e de nutrientes. Já os alimentos mais consistentes oferecidos em momento inoportuno podem causar dificuldades de ingestão para a criança e comprometer a quantidade consumida (PAHO/WHO 2004).

Segundo a OMS e a Organização Panamericana da Saúde (OPAS) aos 6 meses as crianças podem comer alimentos em forma de purê, amassados e semisólidos e deve-se aumentar a consistência de modo gradativo (PAHO/WHO 2004). Com base em revisão da literatura, DEWEY e BROWN (2003) afirmam que aos 12 meses de idade a maioria das crianças está apta a consumir os alimentos da família.

A grande necessidade energética das crianças e a limitada capacidade gástrica tornam o alcance da quantidade de energia fornecida um desafio, particularmente se a densidade energética da dieta é baixa ou se poucas refeições são ofertadas a cada dia (LUTTER e RIVERA 2003). Além disso, as escolhas alimentares, especialmente, devem ser consideradas para atingir as recomendações nutricionais. 
No Brasil observa-se o uso predominante de alimentos lácteos, a monotonia alimentar e inadequação energética e de nutrientes (MS 2002).

Em 1998 a OMS descreveu os "nutrientes-problemas" como aqueles em que há maior discrepância entre seus conteúdos nos alimentos complementares e as quantidades necessárias, considerando as densidades nutricionais (conteúdo de cada nutriente/100kcal). Ao analisar os dados de Bangladesh, Ghana, Guatemala, México e Peru, DEWEY e BROWN (2003) observaram que o ferro, o zinco e a vitamina $B_{6}$ são os "nutrientes-problema" na maioria dos países em desenvolvimento, e a riboflavina e a niacina em algumas populações.

ANDERSON e col (2008), em estudo transversal com 251 crianças de 6 a 36 meses do Camboja com déficit de altura para idade (stunting), encontraram alto consumo de snacks não nutritivos, como batata chips e biscoitos, consumo de leite materno concomitante com mamadeira por $1 / 3$ das crianças e oferta frequente de chá, café e bebidas açucaradas. A dieta encontrava-se pobre em vitamina A, zinco, cálcio e ferro. Além disso, foi encontrado baixo consumo de proteína animal e densidades nutricionais dos alimentos complementares inferiores às desejáveis.

GIBSON e col (1998) analisaram alimentos complementares baseados em receitas típicas de países africanos, da Índia, de Papua Nova Guiné, das Filipinas e da Tailândia. Muitos não atingiram as recomendações de zinco, além de terem altos níveis de fitatos e baixa biodisponibilidade de ferro e de zinco. Praticamente todos os alimentos não atingiram os níveis desejáveis de cálcio e ferro. 


\subsection{JUSTIFICATIVA DO ESTUDO}

Estimativas recentes sobre as principais causas de morte de crianças em todo o mundo (GLOBAL HEALTH COUNCIL 2006; BRYCE e col 2005; JONES e col 2003) mostram que muitas mortes poderiam ser prevenidas com a combinação de aleitamento materno exclusivo até os seis meses e práticas adequadas de alimentação complementar.

Melhorar a qualidade da alimentação complementar tem sido citado como uma das estratégias mais efetivas para a manutenção da saúde e redução da morbi-mortalidade de crianças pequenas (KREBS e HAMBIDGE 2007).

Segundo STOLTZFUS (2008), o maior foco das pesquisas sobre deficiência de ferro na infância deve considerar a questão da alimentação complementar apropriada para crianças de 6 meses a 24 meses de idade. Nesse período, o risco para deficiência de ferro é alto e condicionado por uma dieta pobre em ferro biodisponível e por eventos prévios como anemia na gestação, o clampeamento precoce do cordão umbilical e a interrupção do aleitamento materno exclusivo antes dos 6 meses de idade.

A alta prevalência de anemia aos 6 meses de idade indica que as crianças estão se tornando anêmicas antes que o esperado, e um número muito maior de crianças devem ser deficientes de ferro, mas ainda não desenvolveram anemia (LUTTER 2008).

A saúde das crianças brasileiras tem apresentado melhores condições nos últimos anos. No entanto, estas melhores condições têm sido menos marcantes na região Norte (MONTEIRO 2003). 
No estado do Acre, as deficiências educacionais, habitacionais, de acesso ao saneamento básico e de assistência à saúde são grandes. No relatório do Índice de Desenvolvimento Infantil (IDI) de 2004 (UNICEF 2006) o estado do Acre obteve o índice de 0,516, o segundo pior do Brasil. O IDI nacional foi de 0,667 e no município de Acrelândia o IDI foi menor ainda: 0,433. Este índice, desenvolvido pelo UNICEF, é composto por cinco indicadores: percentual de crianças de até 6 anos de idade morando com mães de escolaridade menor que quatro anos; percentual de crianças de até 6 anos de idade morando com pais de escolaridade menor que quatro anos; cobertura vacinal em crianças menores de 1 ano de idade; percentual de mães com mais de seis consultas pré-natal; e percentual de crianças matriculadas na pré-escola.

Segundo dados do Sistema de Informação sobre Mortalidade (SIM) e o Sistema de Informação sobre Nascidos Vivos (SINASC) de 2005, no Acre morrem 29,48 crianças menores de 1 ano a cada 1000 nascidos vivos, enquanto que no Brasil este número é de 21,17 (DATASUS 2009).

Nos últimos anos, muitos estudos brasileiros têm investigado o efeito do aleitamento materno e da alimentação artificial na prevalência da anemia (ASSIS e col 2004; SZARFARC e col 2004; SILVA e col 2001; NEUMANN e col 2000; MONTEIRO e col 2000; SOUZA e col 1997; SZARFARC e col 1996). São escassos no Brasil estudos de base populacional com avaliação criteriosa do padrão alimentar e de indicadores antropométricos e bioquímicos do estado nutricional infantil, sobretudo na região norte do país.

O presente estudo é do tipo transversal de base populacional cuja coleta de dados foi realizada nos meses de novembro e dezembro de 2007. Foram realizados inquéritos domiciliares, exames laboratoriais e medidas antropométricas. Faz parte 
de um conjunto de pesquisas epidemiológicas sobre condições de saúde e nutrição no estado do Acre intitulado "Condições de Saúde e Nutrição de Crianças da Amazônia Ocidental Brasileira". Foi realizado em colaboração com a Universidade Federal do Acre, a Faculdade de Saúde Pública e o Instituto de Ciências Biomédicas da Universidade de São Paulo. 


\section{OBJETIVO}

Investigar as práticas de alimentação complementar e estado nutricional de crianças menores de 24 meses residentes em Acrelândia, Estado do Acre, Amazônia Ocidental Brasileira. 


\section{MÉTODOS}

\section{1 ÁREA DE ESTUDO}

Este estudo foi realizado na área urbana do município de Acrelândia, que está localizado a $100 \mathrm{~km}$ de Rio Branco e possui fronteira internacional com a Bolívia e fronteiras estaduais com Rondônia e Amazonas.

Estima-se sua população atual em 11.520 habitantes (IBGE 2007), sendo que $44,18 \%$ residem no meio urbano (IBGE 2000). A taxa de analfabetismo do município é de 24,3\% (IBGE 2000). Foi povoado por famílias de agricultores provenientes das regiões Centro-Oeste e Sul do Brasil, participantes de projetos de assentamentos rurais do Instituto Nacional de Colonização e Reforma Agrária. A principal atividade econômica é a agricultura, seguida da exploração da madeira e da castanha do Brasil. Acrelândia está entre os municípios brasileiros com piores indicadores socioeconômicos (BENÍCIO e MONTEIRO 1997).

\subsection{POPULAÇÃO DE ESTUDO}

Com base nos registros do PSF na área urbana do município de Acrelândia, foram localizados 749 domicílios com crianças na faixa etária de 0 a 10 anos. Assim, no mês de novembro de 2007, foi possível identificar 1225 crianças menores de 10 anos. Nesta época, todos os 749 domicílios foram visitados. Os entrevistadores apresentavam os objetivos da pesquisa e convidavam os pais ou responsáveis das crianças à participação no estudo sem nenhum prejuízo para não participação. Dos 749 domicílios com crianças menores de 10 anos, houve 13 recusas e 2 domicílios fechados. Desta forma, o questionário com informações sociodemográficas (ANEXO 
1) foi aplicado em 734 domicílios, totalizando 1225 crianças. Destas, 9 crianças (6 domicílios) não completaram o questionário sobre perfil de saúde (ANEXO 2). Dentre os que completaram os questionários $(n=1216)$, 65 crianças não completaram o exame físico para coleta de amostras sanguíneas, totalizando $\mathbf{1 1 5 1}$ crianças menores de 10 anos com dados completos (94\% dos 1225 elegíveis no município).

A população de interesse para o presente estudo foi a de crianças de 6 a 24 meses. Do total de 235 crianças menores de 24 meses que participaram do estudo principal, 201 tinham entre 6 e 24 meses de idade. Dessas crianças, 166 completaram o histórico alimentar. Domicílios em que não foram encontrados moradores após 3 tentativas ou domicílios não localizados (problemas com 0 endereço) resultaram nas 35 crianças de 6 a 24 meses que não tiveram o histórico alimentar completo. A idade média (DP) dessas crianças foi de 20,1 $(5,43)$ meses, $45,7 \%$ eram do sexo feminino e $54,3 \%$ do sexo masculino. Apenas 2 crianças tinham entre 6 e 8 meses, 2 entre 9 e 11 meses e 31 de 12 a 24 meses. Os valores médios dos índices peso/estatura (DP), estatura/idade (DP) e peso/idade (DP), em escores-Z, foram de: 0,36 (1,01); $-0,38(1,34)$ e 0,08 $(1,13)$; respectivamente.

\subsection{COLETA DE DADOS}

A equipe de trabalho de campo foi constituída pela equipe de pesquisadores do estudo (incluindo médicos e nutricionistas), graduandos e pós-graduandos da USP e da UFAC, agentes comunitários de saúde (ACS) e profissionais de saúde do Programa de Saúde da Família (PSF). 
A coleta de dados do inquérito alimentar ocorreu entre os dias 2 e 22 de Dezembro de 2007, época chuvosa na região, com aplicação de inquérito alimentar (ANEXO 3) e exame clínico que incluiu medidas antropométricas e coleta de amostras de sangue e fezes.

\subsubsection{Inquérito Domiciliar}

Após um período de treinamento realizado pela equipe de pesquisadores do estudo, os ACS, em entrevistas domiciliares, aplicaram 2 tipos de questionários aos pais ou responsáveis pelas crianças. O primeiro investigava as condições sócioeconômicas e ambientais da família e o segundo foi utilizado para obter informações sobre história de saúde e nutrição da criança, incluindo dados sobre condições de aleitamento materno e época de introdução de alimentos. Os pesquisadores supervisionaram diretamente o processo de aplicação destes questionários.

No momento da visita domiciliar foram agendados os exames físicos (coleta de sangue, avaliação antropométrica e entrega das amostras de fezes).

O consumo e práticas alimentares das crianças menores de dois anos também foram obtidas em entrevistas domiciliares por nutricionistas da equipe de pesquisadores.

\subsubsection{Avaliação do consumo alimentar}

No questionário sobre as características da criança eram investigadas informações sobre o tempo de aleitamento materno, aleitamento materno exclusivo e aleitamento materno predominante, e época de introdução de alimentos. 
O consumo alimentar foi avaliado através de histórico alimentar baseado em publicação anterior (WHARF e col 1997), adaptado para o presente estudo. O inquérito alimentar foi aplicado por nutricionistas da equipe de pesquisadores do projeto. As quantidades de alimentos foram expressas em medidas caseiras relatadas pelas mães ou responsáveis, utilizando-se recipientes graduados para conversão das medidas em equivalentes em gramas ou mililitros nos domicílios.

O volume de leite materno consumido foi calculado segundo a fórmula proposta por DREWETT e col (1989) e utilizado no Brasil por NEJAR e col (2004) que considera o número de mamadas durante 24 horas e a idade da criança.

\subsubsection{Avaliação antropométrica}

A avaliação antropométrica foi realizada na Unidade Básica de Saúde do Município por pesquisadores treinados seguindo os procedimentos padronizados da Organização Mundial da Saúde (WHO 1995).

Para avaliar o peso das crianças foi utilizada balança portátil (tipo "pesa bebê"), com capacidade de $25 \mathrm{~kg}$ e precisão de $100 \mathrm{~g}$. O comprimento foi avaliado por meio de infantômetro portátil, colocado sobre uma superfície plana, com precisão de $1 \mathrm{~mm}$.

As medidas foram realizadas em duplicata e de modo sequencial. $\mathrm{O}$ valor médio das duas medidas repetidas foi utilizado nas análises dos dados.

Os escores Z dos índices Altura/Idade (A/I), Peso/Idade (P/I) e Peso/Altura (P/A) foram obtidos a partir do software WHO Athro version 2 (WHO 2007b). Para determinação dos déficits utilizou-se o ponto de corte de -2 escore Z (WHO 1995). Para a definição de excesso de peso foi utilizado o ponto de corte de +2 escore $Z$ 
do índice peso/altura (WHO 1995). Foram excluídos das análises os valores extremos abaixo de -6 escore $Z$ e acima de +6 escore $Z$.

\subsubsection{Avaliação de indicadores bioquímicos}

A coleta sanguínea foi realizada na Unidade Básica de Saúde do Município por membros da equipe do projeto e auxiliares de enfermagem treinados. 0 exame clínico foi agendado com antecedência orientando-se para que a criança comparecesse em jejum de $10 \mathrm{~h}$ a $12 \mathrm{~h}$.

Para cada participante, amostras sanguíneas foram obtidas em dois tubos de ensaio: a) tubo seco para obtenção do soro (tubo envolto em papel alumínio para proteção da luz) mantido em temperatura ambiente em até 1 hora após a coleta; e b) tubo com EDTA para obtenção do plasma, mantido em gelo para centrifugação em até 30 minutos após a coleta.

A quantificação da concentração de hemoglobina foi realizada através de um contador de células sanguíneas automático (ABX Micro 60, HORIBA, Montpellier, França). Quando não foi possível realizar a coleta de sangue venoso foi utilizado o hemoglobinômetro portátil (Hemocue ${ }$, Ängelhom, Suécia) para análise em amostra de sangue obtida por punção digital.

Para a quantificação das reservas orgânicas de ferro foram determinados os níveis plasmáticos de ferritina e de receptor de transferrina (RTf). As dosagens foram realizadas pelo método imunoensaio enzimático de ELISA (Ramco Laboratories, EUA) no Laboratório de Nutrição Humana da FSP/USP.

As análises para ácido fólico e vitamina $B_{12}$ séricos foram realizadas por técnica de fluoroimunoensaio tempo-resolvido (kits PerkinElmer, Wallac Ou, Turku, 
Finland). As análises para retinol sérico (vitamina A) foram realizadas por Cromatografia líquida de alto desempenho em fase reversa (HPLC-110, Hewlett Packard, EUA), conforme metodologia adaptada de VUILLEUMIER e col (1983).

Para classificação das variáveis bioquímicas na população estudada foram utilizados os pontos de corte indicados na tabela abaixo. 
Critérios para interpretação das variáveis bioquímicas.

\begin{tabular}{|c|c|c|c|}
\hline $\begin{array}{c}\text { Variáveis } \\
\text { bioquímicas }\end{array}$ & Valores & Interpretação & Referências \\
\hline Ácido fólico (nmol/L) & $\begin{array}{l}\geq 6,8 \mathrm{nmol} / \mathrm{L} \\
<6,8 \mathrm{nmol} / \mathrm{L}\end{array}$ & $\begin{array}{l}\text { Normalidade } \\
\text { Deficiência }\end{array}$ & PerkinElmer* \\
\hline $\begin{array}{l}\text { Vitamina } B_{12} \\
(\mathrm{pmol} / \mathrm{L})\end{array}$ & $\begin{array}{l}\geq 148 \mathrm{pmol} / \mathrm{L} \\
<148 \mathrm{pmol} / \mathrm{L}\end{array}$ & $\begin{array}{l}\text { Normalidade } \\
\text { Deficiência }\end{array}$ & CARMEL (2006) \\
\hline Retinol $(\mu \mathrm{mol} / \mathrm{L})$ & $\begin{array}{l}\geq 0,7 \mu \mathrm{mol} / \mathrm{L} \\
<0,7 \mu \mathrm{mol} / \mathrm{L}\end{array}$ & $\begin{array}{l}\text { Normalidade } \\
\text { Deficiência de vitamina } \\
\text { A }\end{array}$ & WHO (1996) \\
\hline
\end{tabular}

Os casos de anemia foram diagnosticados apenas para as crianças maiores de 6 meses quando os valores de hemoglobina se encontravam inferiores a 11,0 $\mathrm{g} / 100 \mathrm{~mL}$ (WHO 2001). Foram consideradas deficientes de ferro as crianças que apresentaram valores de ferritina inferiores a 12,0 $\mu \mathrm{g} / \mathrm{L}$ (WHO 2001) e/ou de RTf acima de $8,3 \mathrm{mg} / \mathrm{L}$. A faixa de normalidade do RTf determinada pelo fabricante do kit de análise é de 2,9-8,3mg/L (Ramco Laboratories, EUA). A anemia ferropriva foi determinada para as crianças que tiveram diagnóstico de anemia e de deficiência de ferro.

\subsubsection{Exame parasitológico de fezes}

Durante a visita domiciliar foram feitas orientações padronizadas para coleta de amostra fecal em frascos Coprotest $₫$, sendo que a entrega das amostras deveria ser realizada no dia agendado para o exame clínico. Amostras fecais foram solicitadas a todas as crianças participantes da pesquisa. 
Os exames foram realizados no laboratório de campo na UFAC, em Rio Branco. Todas as amostras fecais foram submetidas a um exame qualitativo de triagem baseado no método de HOFFMAN e col (1934).

\subsection{PROCESSAMENTO E ANÁLISE DOS DADOS}

Para o presente estudo, somente as crianças de 6 a 24 meses foram consideradas na análise com ênfase na alimentação complementar. Os dados das crianças menores de 6 meses foram utilizados para descrever o aleitamento materno exclusivo e introdução precoce de alimentos complementares.

Os Inquéritos Alimentares foram revisados convertendo-se as medidas caseiras relatadas pelos entrevistados em gramas, de acordo com a literatura atual e com dados coletados dos domicílios da população de estudo. As receitas citadas foram desmembradas em ingredientes para cálculo de valor nutricional.

Após esta etapa foi realizada a digitação dos dados das dietas no software World Food Dietary Assessment System versão 2.0. para análise nutricional e cálculos das biodisponibilidades de ferro e zinco das dietas. A tabela de composição de alimentos foi complementada com o valor nutricional do leite materno obtido a partir da tabela do USDA (USDA 2008) e com os conteúdos de ferro e de ácido fólico das farinhas fortificadas do Brasil segundo dados da ANVISA (MS 2008c).

As quantidades de folato e niacina consumidas por cada criança foram transformadas para "equivalentes de folato dietético" (EFD) e "equivalentes de niacina" devido à recomendação destes nutrientes serem apresentadas nestas unidades de medida. Para a transformação em EFD utilizou-se o cálculo recomendado pela WHO (2004): 
$1 \mu \mathrm{g}$ de EFD $=1 \mu \mathrm{g}$ de folato presente nos alimentos $=0,6 \mu \mathrm{g}$ de ácido fólico presente nos alimentos fortificados.

Desta forma, o folato presente nos alimentos que continham farinhas de trigo e/ou de milho e nos espessantes foi contabilizado separadamente devido à fortificação de farinhas praticada no Brasil.

Para a transformação em "equivalentes de niacina" somou-se o valor da ingestão de niacina pré-formada com a niacina que é sintetizada a partir do triptofano da dieta, utilizando-se a conversão recomendada pela WHO (2004):

$60 \mathrm{mg}$ de triptofano $=1 \mathrm{mg}$ de niacina.

A avaliação da dieta complementar em relação às praticas alimentares foi realizada segundo presença de certos grupos de alimentos, prática de aleitamento materno e características de consistência da dieta de acordo com as recomendações do Ministério da Saúde (MS 2002). Os indicadores foram baseados na publicação "10 passos para uma alimentação saudável - Guia alimentar para crianças menores de 2 anos" (MS 2002).

Todos os alimentos foram agrupados para facilitar as análises. Os grupos foram: Açúcar; Café; Carnes; Cereais/Tubérculos/Massas; Condimentos; Doces; Embutidos; Espessantes; Feijões; Fórmula infantil; Frutas/sucos de frutas naturais; Hortaliças; Laticínios; Castanhas; Leite materno; Macarrão instantâneo; Óleos e gorduras; Ovos; Pães/biscoitos doces; Refrigerantes; Salgadinho.

Os alimentos que compuseram cada grupo estão relacionados abaixo:

- Açúcar: açúcar refinado de adição, suco em pó.

- $\quad$ Café: café em infusão. 
- $\quad$ Carnes: carne de boi, frango, peixe.

- Cereais/Tubérculos/Massas: arroz, batata, biscoito salgado tipo creamcracker, farinha de mandioca, pães salgados (francês, fôrma, caseiro, integral).

- Condimentos: caldos de carne e de galinha.

- Doces: achocolatados, balas, biscoito doce recheado, bombom, chocolate em barra.

- $\quad$ Embutidos: presunto, salsicha.

- Espessantes: araruta, Arrozina $\AA$, aveia, Cremogema $\AA$, Maisena $₫$, Mucilon®.

- $\quad$ Feijões: feijão carioca.

- $\quad$ Fórmula infantil: $N A N \AA$, Nestogeno ${ }^{\circledR}$.

- Frutas/sucos de frutas naturais: abacate, água de coco, banana, caju, goiaba, laranja, maçã, mamão, manga, melancia, pêra, polpa de coco, suco de abacaxi, suco de acerola, suco de laranja, suco de limão, suco de maracujá, uva.

- Hortaliças: abóbora, alface, beterraba, brócolis, cebola, cenoura, couve, molho de tomate, pepino, repolho, tomate.

- $\quad$ Laticínios: leite de vaca fluido, leite em pó, iogurte, queijo.

- Castanhas: castanha do Pará.

• Macarrão instantâneo: macarrão instantâneo tipo Miojo®

- $\quad$ Óleos e gorduras: manteiga, margarina, batata frita, óleo de soja. 
- Ovos: ovo de galinha.

- Pães/biscoitos doces: biscoito tipo Maisena $\Re$, pão doce simples, bolo simples.

- $\quad$ Refrigerantes: refrigerantes açucarados.

- $\quad$ Salgadinho: salgadinhos de milho (tipo Cheetos $®$ ).

A população analisada foi estratificada em 3 grupos etários ( 6 a 8 meses, 9 a 11 meses e 12 a 24 meses) devido às importantes diferenças em relação às recomendações de práticas de alimentação complementar e às recomendações de nutrientes. Os valores nutricionais provenientes dos dados de consumo alimentar foram confrontados com as recomendações atuais para a faixa etária (WHO 2004). A análise da biodisponibilidade de ferro e zinco da dieta foi realizada segundo recomendações da OMS (WHO 2001).

Foram calculadas as frequências relativas e absolutas, médias (desviospadrão) e medianas (intervalos interquartis) das variáveis. Os dados bioquímicos e de consumo alimentar (energia, nutrientes e densidade) foram apresentados com seus valores medianos e os respectivos intervalos interquartis devido à grande variabilidade da distribuição.

O cálculo das densidades nutricionais medianas dos alimentos complementares foi baseado no documento de DEWEY e BROWN de 2003. No caso das crianças amamentadas foi retirado leite materno da dieta, conforme a recomendação dos autores.

De acordo com a porcentagem de ferro biodisponível, a dieta pôde ser classificada desde "Muito baixa" até "Alta" e definir as recomendações de consumo 
diário segundo essa biodisponibilidade. Os critérios de classificação são os seguintes (WHO 2001b):

- Muito baixa: $~ 5 \%$ ou menos

- Baixa: 10\%

- Moderada: $12 \%$

Alta: $~ 15 \%$ ou mais

Os testes do qui-quadrado e a ANOVA foram utilizados, respectivamente, para comparações entre proporções e médias entre os grupos etários, utilizando-se nível de significância $\mathrm{p}<0,05$.

\subsection{ASPECTOS ÉTICOS}

Os entrevistadores se identificaram, explicaram os objetivos e benefícios da pesquisa, solicitando participação voluntária mediante consentimento esclarecido (ANEXO 4) por escrito aos pais ou responsável (is) pela(s) criança(s). Foi assegurado sigilo das informações obtidas e apresentação dos resultados individuais e da pesquisa oportunamente.

As crianças anêmicas diagnosticadas durante 0 estudo receberam tratamento medicamentoso adequado fornecido e orientado pela equipe médica do projeto de pesquisa, em parceria com o PSF.

Os pais de crianças com desvios nutricionais (<-2escore-Z para os índices antropométricos peso/altura, altura/idade e/ou peso/idade) foram orientados a procurarem atendimento médico junto ao PSF do Município. 
As crianças que apresentaram infestação parasitária receberam tratamento medicamentoso adequado fornecido e orientado pela equipe médica do projeto de pesquisa em parceria com o PSF.

O projeto de pesquisa foi aprovado pelo Comitê de Ética da Faculdade de Saúde Pública (ANEXO 5). 


\section{RESULTADOS}

\subsection{CARACTERIZAÇÃO DA POPULAÇÃO DE ESTUDO}

Não foram encontradas diferenças estatisticamente significantes entre a população do presente estudo e as crianças que não completaram histórico alimentar, segundo o teste qui-quadrado, no que se refere às proporções nos grupos etários $\left(\chi^{2}=7,785 ; p=0,051\right)$, distribuição entre os sexos $\left(\chi^{2}=0,367\right.$; $p=0,545)$, prevalência de déficit de estatura/idade $\left(\chi^{2}=3,787 ; p=0,151\right)$, prevalência de déficit de peso/idade $\left(\chi^{2}=0,300 ; p=0,861\right)$ e excesso de peso/estatura $\left(\chi^{2}=3,035 ; p=0,219\right)$.

A Tabela 1 apresenta a distribuição das crianças de 6 a 24 meses do estudo segundo características sócio-demográficas. A média de idade foi de 14,1 meses $(\mathrm{DP}=4,6)$, com o valor mínimo de 6,14 meses e máximo de 24,41 meses. O tempo médio em anos de escolaridade paterna foi de $7,1(D P=4,1)$ e de escolaridade materna foi de $7,1(\mathrm{DP}=3,6)$. Das crianças, $12 \%$ não moravam com suas mães biológicas, sendo que $7,8 \%$ moravam somente com o pai e $4,2 \%$ com nenhum dos pais. Segundo o teste qui-quadrado, foi encontrada diferença estatisticamente significante entre os grupos etários em relação à proporção de crianças que moravam com mãe e pai biológicos $\left(\chi^{2}=14,156 ; p=0,001\right)$. A idade média das mães foi de 27 anos (DP=8) e 68,7\% das mães eram donas de casa

A água dos domicílios era procedente da rede geral de distribuição (59\%) ou de poço (40\%) e a forma de tratamento dessa água era principalmente a adição de cloro nos próprios domicílios (57\%), sendo que em $9 \%$ dos domicílios não havia nenhum tratamento. Em relação ao sanitário existente no domicílio observou-se que 
31,5\% não possuíam vaso sanitário. O lixo era coletado pelo serviço público em $98,2 \%$ dos casos.

A participação no Programa Bolsa Família foi de $11,1 \%$ e na Pastoral da Criança foi de $14,7 \%$.

Não houve diferença estatisticamente significante entre os grupos etários com relação às demais variáveis descritas. 
Tabela 1. Distribuição de crianças (\%) segundo características sociodemográficas por grupo etário. Acrelândia, Acre, 2007.

Variáveis

\begin{tabular}{cccc}
$\begin{array}{c}6 \text { a } 8 \\
\text { meses }\end{array}$ & $\begin{array}{c}9 \text { a } 11 \\
\text { meses }\end{array}$ & $\begin{array}{c}12 \text { a } 24 \\
\text { meses }\end{array}$ & $\begin{array}{c}\text { Total } \\
(n=27)\end{array}$ \\
$(n=31)$ & $(n=108)$ & \\
\hline
\end{tabular}

Sexo

Masculino

$48,1 \quad 54,8 \quad 50,9 \quad 51,2$

Feminino

$51,9 \quad 45,2 \quad 49,1 \quad 48,8$

Escolaridade materna (ensino formal)

Sem escolaridade

De 1 a 4 anos

5 a 8 anos

9 anos ou mais

$\begin{array}{cccc}7,4 & 3,2 & 6,6 & 6,1 \\ 22,2 & 38,7 & 29,2 & 29,9 \\ 40,7 & 29,0 & 27,4 & 29,9 \\ 29,6 & 29,0 & 36,8 & 34,1\end{array}$

Estado marital da mãe

Casada ou mora com companheiro

$81,5 \quad 87,1 \quad 80,6 \quad 81,9$

Solteira

$18,5 \quad 12,9 \quad 19,4 \quad 18,1$

Idade da mãe

Adolescente

$14,8 \quad 22,6$

16,7

17,5

Adulta

$85,2 \quad 77,4 \quad 83,3 \quad 82,5$

\section{Escolaridade paterna (ensino formal)}

Sem escolaridade

$3,8 \quad 10,0 \quad 13,0 \quad 10,7$

De 1 a 4 anos

$38,5 \quad 26,7 \quad 25,9 \quad 28,4$

5 a 8 anos

$26,9 \quad 36,7 \quad 20,0 \quad 24,8$

9 anos ou mais

$30,8 \quad 26,7 \quad 41,2 \quad 36,2$

Morar com os pais biológicos***

Mora com mãe e pai

$77,8 \quad 96,8 \quad 63,0 \quad 71,7$

Mora com 1 dos pais ou nenhum

$22,2 \quad 3,2 \quad 37,0 \quad 28,3$

\section{Esgotamento sanitário}

Rede coletora de esgoto

Fossa

Esgoto a céu aberto

$\begin{array}{cccc}7,7 & 3,2 & 0,0 & 1,8 \\ 84,6 & 83,9 & 95,3 & 91,5 \\ 7,7 & 9,7 & 3,7 & 5,5\end{array}$

\section{Abastecimento de água}

Rede geral

Poço artesiano ou nascente

Outra

$\begin{array}{cccc}55,6 & 61,3 & 59,8 & 59,4 \\ 44,4 & 38,7 & 39,3 & 40,0 \\ 0,0 & 0,0 & 0,9 & 0,6\end{array}$

Participação no Programa Bolsa Família

$7,4 \quad 6,7 \quad 13,3 \quad 11,1$

Participação na Pastoral da Criança

$22,2 \quad 10,0 \quad 14,2 \quad 14,7$

\footnotetext{
$* * *$ Teste qui-quadrado, $\mathrm{p} \leq 0,001$
} 


\subsection{MORBIDADES E ESTADO NUTRICIONAL}

Com relação ao peso ao nascer, 7,2 \% das crianças apresentaram baixo peso (abaixo de $2500 \mathrm{~g}$ ). A prevalência de parasitas intestinais foi de $25,5 \%$, sendo que $80 \%$ das infecções foram causadas por Giardia lamblia e $17,1 \%$ por Endolimax nana. Das mães, $21,3 \%$ afirmaram que as crianças fizeram uso de remédios antiparasitários nos últimos 6 meses e 16,0\% que usaram suplementos vitamínicos ou fortificantes nos últimos 30 dias anteriores à pesquisa.

Na Tabela 2 é apresentada a distribuição das crianças segundo morbidade e estado nutricional por grupo etário. Observou-se prevalência de anemia de $40,0 \%$, deficiência de ferro (isolada, sem anemia) de 44,2\% e anemia ferropriva, $38,1 \%$. O déficit de estatura para a idade (<-2 escore Z) esteve presente em $12,3 \%$ das crianças. A média (DP) de escore $Z$ de peso para idade foi de $0,05(1,08)$ e a prevalência de déficit foi de $1,9 \%$. A média (DP) de escore $Z$ de peso para idade foi de $0,36(0,98)$ e o excesso de peso para estatura $(>+2$ escore $Z)$ foi encontrado em $3,9 \%$ das crianças. Não houve diferenças estatisticamente significantes entre as freqüências dos distúrbios nutricionais segundo grupos etários. 
Tabela 2. Distribuição de crianças segundo morbidade e estado nutricional por grupo etário. Acrelândia, Acre, 2007.

\begin{tabular}{|c|c|c|c|c|}
\hline Variáveis & $\begin{array}{c}6 \text { a } 8 \\
\text { meses } \\
(n=27)\end{array}$ & $\begin{array}{l}9 \text { a } 11 \\
\text { meses } \\
(n=31)\end{array}$ & $\begin{array}{c}12 \text { a } 24 \\
\text { meses } \\
(n=108)\end{array}$ & $\begin{array}{c}\text { Total } \\
(n=166)\end{array}$ \\
\hline Diarréia referida nos últimos 15 dias & 50,0 & 45,2 & 44,9 & 45,7 \\
\hline Deficiência de Ferro & 45,5 & 40,0 & 45,0 & 44,2 \\
\hline Anemia & 45,5 & 48,3 & 36,9 & 40,0 \\
\hline Anemia ferropriva & 45,5 & 40,0 & 36,0 & 38,1 \\
\hline \multicolumn{5}{|l|}{ Estatura/Idade } \\
\hline $\begin{array}{l}\text { Média (DP) em escore } Z \\
<-2 \text { escore } Z(\%)\end{array}$ & $\begin{array}{c}-0,78(1,14) \\
12,0\end{array}$ & $\begin{array}{c}-0,06(1,35) \\
6,9\end{array}$ & $\begin{array}{c}-0,39(1,27) \\
13,9\end{array}$ & $\begin{array}{c}-0,39(1,27) \\
12,3\end{array}$ \\
\hline
\end{tabular}

Os valores de referência, medianas e intervalos interquartis das concentrações sanguíneas de hemoglobina, ferritina, receptor de transferrina, vitamina $B_{12}$, ácido fólico e vitamina $A$ são apresentados por grupo etário na Tabela 3. Observou-se que a deficiência de ácido fólico foi de $2,2 \%$, de vitamina $B_{12}$ foi de $11,7 \%$ e de vitamina $A$ foi de $14,9 \%$. Não houve diferença estatisticamente significante entre os grupos etários para nenhuma dessas variáveis. 
Tabela 3. Valores de referência e medianas (intervalos interquartis) das concentrações sanguíneas de hemoglobina, ferritina, receptor de transferrina, vitamina $B_{12}$, ácido fólico e vitamina A por grupo etário. Acrelândia, Acre, 2007.

\begin{tabular}{|c|c|c|c|c|c|}
\hline Variáveis & $\begin{array}{l}\text { Refe- } \\
\text { rência }\end{array}$ & $\begin{array}{c}6 \text { a } 8 \text { meses } \\
(n=27)\end{array}$ & $\begin{array}{l}9 \text { a } 11 \\
\text { meses } \\
(n=31)\end{array}$ & $\begin{array}{c}12 \text { a } 24 \\
\text { meses } \\
(n=108)\end{array}$ & $\begin{array}{c}\text { Total } \\
(n=166)\end{array}$ \\
\hline $\begin{array}{l}\text { Hemoglobina } \\
(\mathrm{g} / 100 \mathrm{~mL})\end{array}$ & $\geq 11,00$ & $\begin{array}{c}11,10 \\
(10,4 ; 11,7)\end{array}$ & $\begin{array}{c}11,10 \\
(10,4 ; 11,7)\end{array}$ & $\begin{array}{c}11,5 \\
(10,4 ; 12,1)\end{array}$ & $\begin{array}{c}11,2 \\
(10,4 ; 12,0)\end{array}$ \\
\hline $\begin{array}{l}\text { Ferritina } \\
(\mu \mathrm{g} / \mathrm{L})\end{array}$ & $\geq 12,00$ & $\begin{array}{c}12,75 \\
(5,5 ; 23,9)\end{array}$ & $\begin{array}{c}12,55 \\
(5,0 ; 30,1)\end{array}$ & $\begin{array}{c}10,7 \\
(5,2 ; 19,0)\end{array}$ & $\begin{array}{c}11,97 \\
(5,2 ; 19,7)\end{array}$ \\
\hline $\begin{array}{l}\text { Vitamina } B_{12} \\
(\mathrm{pmol} / \mathrm{L})\end{array}$ & $\geq 148,00$ & $\begin{array}{c}265,00 \\
(174,2 ; \\
298,0)\end{array}$ & $\begin{array}{c}183,00 \\
(168,0 ; \\
242,0)\end{array}$ & $\begin{array}{c}252,00 \\
(189,0 ; \\
317,0)\end{array}$ & $\begin{array}{c}239,00 \\
(180,2 ; \\
306,5)\end{array}$ \\
\hline $\begin{array}{l}\text { Ácido Fólico } \\
\text { (nmol/L) }\end{array}$ & $\geq 6,80$ & $\begin{array}{c}29,00 \\
(17,7 ; 39,1)\end{array}$ & $\begin{array}{c}21,05 \\
(17,7 ; 29,0)\end{array}$ & $\begin{array}{c}21,65 \\
(17,1 ; 33,4)\end{array}$ & $\begin{array}{c}22,10 \\
(17,5 ; 33,6)\end{array}$ \\
\hline $\begin{array}{l}\text { Vitamina A } \\
\text { ( } \mu \mathrm{mol} / \mathrm{L})\end{array}$ & $\geq 0,70$ & $\begin{array}{c}1,23 \\
(0,9 ; 1,7)\end{array}$ & $\begin{array}{c}1,14 \\
(1,0 ; 1,6)\end{array}$ & $\begin{array}{c}1,10 \\
(0,8 ; 1,4)\end{array}$ & $\begin{array}{c}1,12 \\
(0,9 ; 1,5)\end{array}$ \\
\hline
\end{tabular}

\subsection{PRÁTICAS ALIMENTARES}

Praticamente todas as crianças receberam leite materno ao nascer (99\%). O aleitamento materno exclusivo estava sendo praticado em $34,5 \%$ das crianças de 0 a 5 meses no momento da entrevista; $54,2 \%$ destas já utilizavam mamadeira e $50 \%$ já havia iniciado a alimentação pastosa.

Das 166 crianças de 6 a 24 meses de idade, 50,0\% consumiam leite materno e a prática do aleitamento materno exclusivo até o $6^{\circ}$ mês foi referida por 9,64\% das mães. A prevalência de crianças desmamadas com até 6 meses de idade foi de 3,4\%, dos 6 aos 8 meses foi de $29,6 \%$, de 9 a 11 meses foi $25,8 \%$ e dos 12 aos 24 meses foi de $62,0 \%$. O aleitamento materno continuado dos 20 aos 24 
meses foi de $14,3 \%$. Encontrou-se que $79,5 \%$ das crianças que estavam em aleitamento materno também tomavam leite de vaca.

A distribuição das crianças segundo práticas alimentares pode ser vista na Tabela 4. Houve diferenças estatisticamente significantes entre proporções segundo grupos etários para as seguintes variáveis: frequência de consumo de leite materno $\left(\chi^{2}=17,999 ; p=0,000\right)$, frequência de consumo de leite de vaca $\left(\chi^{2}=24,446 ; p=0,000\right)$ proporção de crianças que consumiam pelo menos uma porção de fruta $\left(\chi^{2}=9,791 ; p=0,007\right)$, proporção de crianças que consumiam pelo menos uma refeição de sal $\left(\chi^{2}=12,026 ; p=0,002\right)$, presença de pelo menos uma carne/ovo/feijão na refeição de sal $\left(\chi^{2}=7,942 ; p=0,019\right)$, presença de pelo menos um cereal ou tubérculo na refeição de sal $\left(\chi^{2}=11,122 ; p=0,004\right)$ e consumo de mingau $\left(\chi^{2}=17,404 ; p=0,008\right)$.

Observou-se que 48,2\% das crianças não ingeriam nenhuma fruta e 53,4\% não consumiam nenhuma hortaliça. Em relação à introdução de alimentos complementares, 29,6\% das crianças de 6 a 8 meses ainda não recebiam nenhuma refeição de sal. Em contrapartida, o consumo de mingau apresentou freqüências cada vez maiores conforme aumento da idade. Dentre as crianças que tinham hábito de consumir mingau, 48\% ingeriam essa preparação de 3 a 4 vezes por dia.

O consumo de leite de vaca ou leite materno para complementar as refeições também foi uma prática observada. Ambas diminuem conforme a faixa etária aumenta. $4,3 \%$ das crianças consomem leite de vaca juntamente com refeições de sal e 10,8\% consomem leite materno. 
Tabela 4. Distribuição de crianças (\%) segundo práticas alimentares por grupo etário. Acrelândia, Acre, 2007.

\begin{tabular}{|c|c|c|c|c|}
\hline Indicadores alimentares $\dagger$ & $\begin{array}{c}6 \text { a } 8 \\
\text { meses } \\
(n=27)\end{array}$ & $\begin{array}{c}9 \text { a } 11 \\
\text { meses } \\
(n=31)\end{array}$ & $\begin{array}{c}12 \text { a } 24 \\
\text { meses } \\
(n=108)\end{array}$ & $\begin{array}{c}\text { Total } \\
(n=166)\end{array}$ \\
\hline Consumo de leite materno*** & 70,4 & 74,2 & 38,0 & 50,0 \\
\hline Consumo de leite de vaca*** & 70,4 & 77,4 & 98,1 & 89,8 \\
\hline $\begin{array}{l}\text { Consumo de leite materno e leite de } \\
\text { vaca }\end{array}$ & 40,7 & 51,6 & 35,2 & 39,2 \\
\hline $\begin{array}{l}\text { Alimentos menos consistentes } \\
\text { que o recomendado }\end{array}$ & 40,7 & 64,5 & 65,7 & 61,4 \\
\hline Consumo de pelo menos uma fruta** & 25,9 & 48,4 & 59,3 & 51,8 \\
\hline $\begin{array}{l}\text { Consumo de pelo menos uma } \\
\text { refeição de sal** }\end{array}$ & 70,4 & 90,3 & 93,5 & 89,2 \\
\hline $\begin{array}{l}\text { Presença de pelo menos uma hortaliça } \\
\text { na refeição de sal }\end{array}$ & 47,4 & 50,0 & 45,5 & 46,6 \\
\hline $\begin{array}{l}\text { Presença de pelo menos um } \\
\text { cereal/tubérculo/massa na refeição de } \\
\text { sal** }\end{array}$ & 89,5 & 89,3 & 100,0 & 96,6 \\
\hline $\begin{array}{l}\text { Presença de pelo menos uma carne, ovo } \\
\text { ou feijão na refeição de sal* }\end{array}$ & 73,7 & 85,7 & 94,1 & 89,9 \\
\hline Uso atual de mamadeira & 100,0 & 94,7 & 95,2 & 95,8 \\
\hline \multicolumn{5}{|l|}{ Consumo de mingau (leite espessado)** } \\
\hline Não consome & 63,0 & 51,6 & 36,1 & 43,4 \\
\hline de 1 a 2 vezes/dia & 11,1 & 16,1 & 26,9 & 22,3 \\
\hline de 3 a 4 vezes/dia & 11,1 & 19,4 & 33,3 & 27,1 \\
\hline 5 vezes ou mais/dia & 14,8 & 12,9 & 3,7 & 7,2 \\
\hline
\end{tabular}

†: Indicadores definidos a partir das recomendações do Ministério da Saúde (2002)

Teste qui-quadrado: $* 00,05 ; * * p \leq 0,01 ; * * * p \leq 0,001$.

Na Figura 1 pode-se visualizar como se comporta a distribuição das crianças segundo consumo de alimentos selecionados que não são recomendados para a faixa etária. Aos 6 meses algumas crianças já recebiam biscoitos e/ou pães 
doces, macarrão instantâneo (miojo $\Re)$ e café. O início da oferta de doces, salgadinhos e refrigerantes para esta população se deu aos 9 meses de idade. É interessante observar que conforme a idade aumenta o consumo de todos estes alimentos também aumenta. Através do teste qui-quadrado foi encontrada diferença estatisticamente significante em relação à frequência de consumo de café $\left(\chi^{2}=\right.$ $11,714 ; p=0,003)$. 
Figura 1. Distribuição das crianças (\%) segundo o consumo de alimentos selecionados por grupo etário. Acrelândia, Acre, 2007.

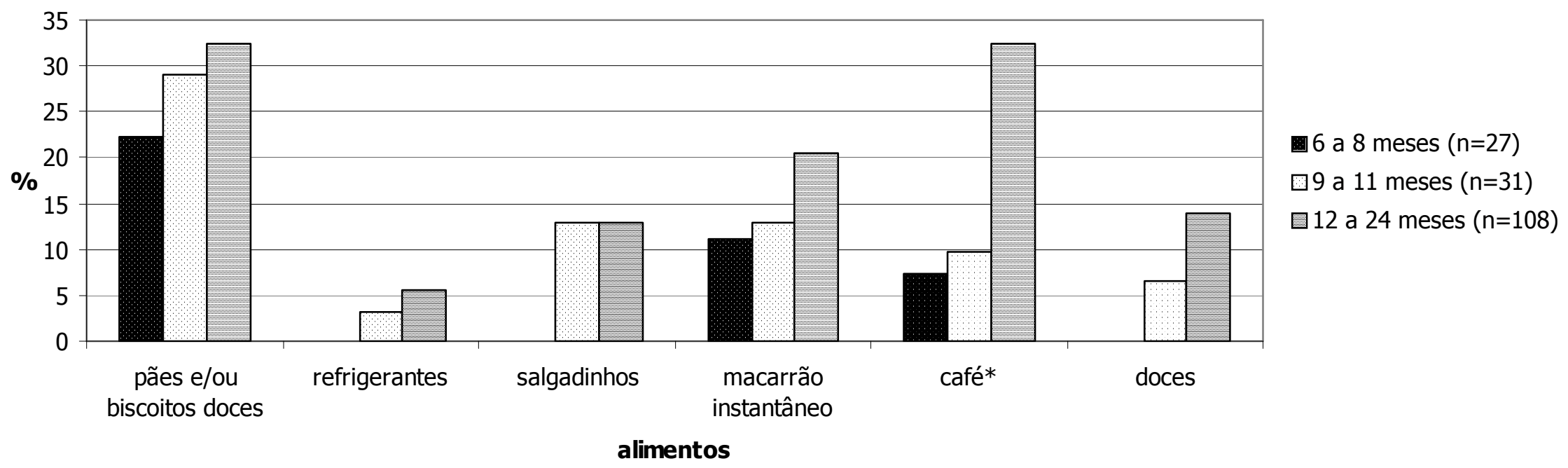

* Teste qui-quadrado, $\mathrm{p}<0,05$. 
A introdução de alimentos precocemente também pôde ser observada. Notou-se que $39,1 \%$ das crianças recebem alimentos pastosos pela primeira vez entre 0 e 5 meses. Porém, a introdução tardia de alimentos também ocorre; 20,0\% das crianças de 6 a 8 meses ainda só se alimentavam de líquidos no momento da entrevista. Esse número cai para 6,7\% entre as crianças de 9 a 11 meses e para 4,0\% nas crianças de 12 a 24 meses.

\subsection{AVALIAÇÃO DO CONSUMO ALIMENTAR}

Os valores medianos e intervalos interquartis do consumo de energia e nutrientes da dieta são apresentados na Tabela 5. O grupo etário de 6 a 8 meses apresentou ingestão mediana menor que a recomendação para muitos nutrientes. 0 único nutriente em que isso ocorreu em todos os grupos etários é o ferro, com grandes diferenças entre o consumo e a recomendação. 
Tabela 5. Valores medianos (intervalo interquartil) para energia e nutrientes do consumo alimentar e das recomendações por grupo etário. Acrelândia, Acre, 2007.

\begin{tabular}{|c|c|c|c|c|c|c|}
\hline \multirow{2}{*}{$\begin{array}{l}\text { Energia/ } \\
\text { Nutrientes }\end{array}$} & \multicolumn{2}{|c|}{$\begin{array}{c}6 \text { a } 8 \text { meses } \\
(n=27)\end{array}$} & \multicolumn{2}{|c|}{$\begin{array}{c}9 \text { a } 11 \text { meses } \\
(n=31)\end{array}$} & \multicolumn{2}{|c|}{$\begin{array}{c}12 \text { a } 24 \text { meses } \\
(n=108)\end{array}$} \\
\hline & Ingestão & $\begin{array}{c}\text { Recomen } \\
\text { dação }\end{array}$ & Ingestão & $\begin{array}{c}\text { Recomen } \\
\text { dação }\end{array}$ & Ingestão & $\begin{array}{c}\text { Recomen } \\
\text { dação }\end{array}$ \\
\hline $\begin{array}{l}\text { Energia } \\
\text { (Kcal) }\end{array}$ & $\begin{array}{c}714,00 \\
(452,00 ; \\
1186,00)\end{array}$ & $\begin{array}{l}652,00 \\
(629- \\
680)^{\dagger}\end{array}$ & $\begin{array}{c}889,00 \\
(707,00 \\
1188,00)\end{array}$ & $\begin{array}{l}702,00 \\
(694- \\
712)^{\dagger}\end{array}$ & $\begin{array}{l}1172,50 \\
(834,75 ; \\
1461,75)\end{array}$ & $\begin{array}{l}948,00 \\
(865- \\
948)^{\dagger}\end{array}$ \\
\hline $\begin{array}{l}\text { Proteína } \\
\text { (g) }\end{array}$ & $\begin{array}{c}22,20 \\
(9,20 ; 38,90)\end{array}$ & 9,10 & $\begin{array}{c}26,10 \\
(19,70 \\
39,50)\end{array}$ & 9,60 & $\begin{array}{c}38,35 \\
(24,82 ; 54,22)\end{array}$ & 10,90 \\
\hline $\begin{array}{l}\text { Tiamina } \\
\text { (mg) }\end{array}$ & $\begin{array}{c}0,23 \\
(0,11 ; 0,44)\end{array}$ & 0,30 & $\begin{array}{c}0,31 \\
(0,24 ; 0,58)\end{array}$ & 0,30 & $\begin{array}{c}0,43 \\
(0,28 ; 0,66)\end{array}$ & 0,50 \\
\hline $\begin{array}{l}\text { Equiv. de } \\
\text { Niacina } \\
\text { (mg) }\end{array}$ & $\begin{array}{c}8,25 \\
(5,60 ; 12,93)\end{array}$ & 4,00 & $\begin{array}{l}11,70 \\
(9,17 ; \\
15,57)\end{array}$ & 4,00 & $\begin{array}{c}14,29 \\
(9,84 ; 21,69)\end{array}$ & 6,00 \\
\hline $\begin{array}{l}\text { Riboflavin } \\
\text { a (mg) }\end{array}$ & $\begin{array}{c}0,77 \\
(0,26 ; 1,48)\end{array}$ & 0,40 & $\begin{array}{c}0,64 \\
(0,39 ; 1,29)\end{array}$ & 0,40 & $\begin{array}{c}1,10 \\
(0,67 ; 1,56)\end{array}$ & 0,50 \\
\hline $\begin{array}{l}\text { Vitamina } \\
\text { B }_{6}(\mathrm{mg})\end{array}$ & $\begin{array}{c}0,40 \\
(0,20 ; 0,79)\end{array}$ & 0,30 & $\begin{array}{c}0,52 \\
(0,30 ; 0,86)\end{array}$ & 0,30 & $\begin{array}{c}0,72 \\
(0,39 ; 1,15)\end{array}$ & 0,50 \\
\hline $\begin{array}{l}\text { Equiv. de } \\
\text { Ácido } \\
\text { fólico }(\mu g)\end{array}$ & $\begin{array}{c}88,00 \\
(64,33 \\
181,33)\end{array}$ & 80,00 & $\begin{array}{c}144,67 \\
(111,00 \\
190,33)\end{array}$ & 80,00 & $\begin{array}{c}184,83 \\
(119,67 \\
248,00)\end{array}$ & 150,00 \\
\hline $\begin{array}{l}\text { Vitamina } \\
B_{12}(\mu g)\end{array}$ & $\begin{array}{c}1,00 \\
(0,27 ; 1,97)\end{array}$ & 0,70 & $\begin{array}{c}1,32 \\
(0,64 ; 1,83)\end{array}$ & 0,70 & $\begin{array}{c}1,40 \\
(0,85 ; 3,19)\end{array}$ & 0,90 \\
\hline $\begin{array}{l}\text { Vitamina } \\
\text { A (RE) }\end{array}$ & $\begin{array}{c}446,00 \\
(288,00 \\
852,00)\end{array}$ & 400,00 & $\begin{array}{c}426,00 \\
(322,00 ; \\
879,00)\end{array}$ & 400,00 & $\begin{array}{c}491,00 \\
(290,00 ; \\
822,50)\end{array}$ & 400,00 \\
\hline $\begin{array}{l}\text { Vitamina } \\
\text { C ( }(\mathbf{m g})\end{array}$ & $\begin{array}{c}27,00 \\
(23,00 ; 39,00)\end{array}$ & 30,00 & $\begin{array}{c}35,00 \\
(29,00 \\
52,00)\end{array}$ & 30,00 & $\begin{array}{c}37,50 \\
(24,00 ; 58,75)\end{array}$ & 30,00 \\
\hline $\begin{array}{l}\text { Cálcio } \\
(\mathbf{m g})\end{array}$ & $\begin{array}{c}488,00 \\
(171,00 \\
1035,00)\end{array}$ & 400,00 & $\begin{array}{c}604,00 \\
(280,00 ; \\
884,00)\end{array}$ & 400,00 & $\begin{array}{c}728,00 \\
(437,50 \\
1103,50)\end{array}$ & 500,00 \\
\hline $\begin{array}{l}\text { Ferro } \\
(\mathrm{mg})\end{array}$ & $\begin{array}{c}1,58 \\
(0,44 ; 3,80)\end{array}$ & $9,30 \Phi$ & $\begin{array}{c}3,15 \\
(2,06 ; 6,17)\end{array}$ & $9,30 \Phi$ & $\begin{array}{c}5,10 \\
(3,15 ; 7,17)\end{array}$ & $5,80 \Phi$ \\
\hline $\begin{array}{l}\text { Zinco } \\
\text { (mg) }\end{array}$ & $\begin{array}{c}3,16 \\
(1,59 ; 5,34)\end{array}$ & $4,10 \zeta$ & $\begin{array}{c}3,47 \\
(2,87 ; 5,19)\end{array}$ & $4,10 \zeta$ & $\begin{array}{c}5,09 \\
(3,07 ; 7,23)\end{array}$ & $4,10 \zeta$ \\
\hline
\end{tabular}

t: Mediana dos valores de recomendação de energia para cada grupo etário (UNU/WHO/FAO 2004).

Recomendação de nutrientes segundo WHO (2004).

Ф: Recomendação para dietas com $10 \%$ de biodisponibilidade de ferro.

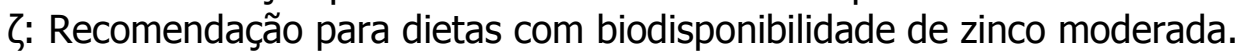

A Figura 2 mostra a proporção de crianças com déficit de ingestão de nutrientes. Houve diferenças estatisticamente significantes entre os grupos etários 
em relação a proporção de crianças com ingestão abaixo das recomendações para os seguintes nutrientes: vitamina $C\left(\chi^{2}=7,641 ; p=0,022\right)$, zinco $\left(\chi^{2}=14,466\right.$; $p=0,001)$, folato $\left(\chi^{2}=7,175 ; p=0,028\right)$ e ferro $\left(\chi^{2}=21,934 ; 0,000\right)$. Do total de participantes do presente estudo $(n=166)$, as proporções de crianças que ingeriram nutrientes em quantidades inferiores à recomendação foram: 70,5\% para ferro, $33,1 \%$ para ácido fólico, 42,2\% para vitamina $A, 40,4 \%$ em relação à vitamina $C$, $30,7 \%$ para vitamina $B_{12}$ e $45,8 \%$ para zinco. 
Figura 2. Distribuição de crianças (\%) com ingestão de nutrientes abaixo das recomendações por grupo etário. Acrelândia, Acre, 2007.

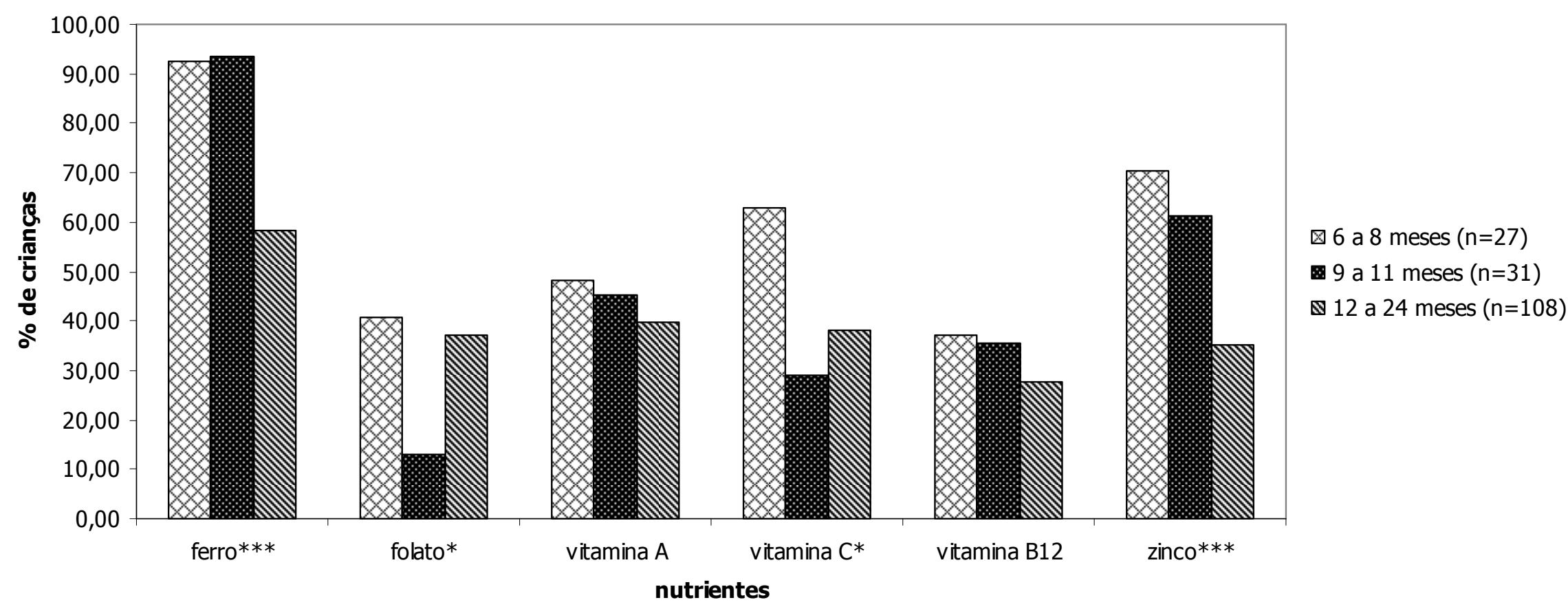

Recomendações de nutrientes segundo WHO (2004).

Teste qui-quadrado: ${ }^{*} \mathrm{p}<0,05 ; * * * \mathrm{p} \leq 0,001$. 
As densidades medianas dos nutrientes (por 100kcal) dos alimentos complementares são apresentadas na Tabela 6. No grupo das crianças em aleitamento materno foram comparadas as proporções de crianças que consumiam alimentos com densidades nutricionais inferiores às desejáveis através do teste quiquadrado. Houve diferença estatisticamente significante em relação ao consumo de proteínas $\left(\chi^{2}=13,367 ; p=0,001\right)$. Observa-se na tabela que, entre as crianças amamentadas, as densidades de proteína, riboflavina e vitamina C encontraram-se adequadas segundo o que a Organização Mundial da Saúde considera desejável nos 3 grupos etários. Já as de tiamina, niacina, cálcio, ferro e zinco encontram-se abaixo das desejáveis nos 3 grupos. Comparando-se os valores das crianças amamentadas e desmamadas é possível observar que as densidades de riboflavina, cálcio e zinco se encontram maiores entre as crianças desmamadas dos 3 grupos enquanto que as densidades de ácido fólico e de vitamina C encontram-se maior entre as amamentadas. 
Tabela 6. Densidade mediana de nutrientes da dieta complementar de crianças amamentadas e desmamadas por grupo etário. Acrelândia, Acre, 2007.

\begin{tabular}{|c|c|c|c|c|c|c|c|c|c|}
\hline \multirow[b]{2}{*}{$\begin{array}{c}\text { Crianças } \\
\text { amamentadas }\end{array}$} & \multicolumn{3}{|c|}{$\begin{array}{c}6 \text { a } 8 \text { meses } \\
(n=27)\end{array}$} & \multicolumn{3}{|c|}{$\begin{array}{c}9 \text { a } 11 \text { meses } \\
(n=31)\end{array}$} & \multicolumn{3}{|c|}{$\begin{array}{c}12 \text { a } 24 \text { meses } \\
(n=108)\end{array}$} \\
\hline & $\begin{array}{c}\text { Desma- } \\
\text { madas } \\
(n=8)\end{array}$ & $\begin{array}{c}\text { Amamen- } \\
\text { tadas } \\
(n=20)\end{array}$ & $\begin{array}{l}\text { Densidade } \\
\text { Desejável } †\end{array}$ & $\begin{array}{c}\text { Desma- } \\
\text { madas } \\
(n=8) \\
\end{array}$ & $\begin{array}{c}\text { Amamen- } \\
\text { tadas } \\
(n=22)\end{array}$ & $\begin{array}{l}\text { Densidade } \\
\text { Desejável } †\end{array}$ & $\begin{array}{c}\text { Desma- } \\
\text { madas } \\
(n=67)\end{array}$ & $\begin{array}{c}\text { Amamen- } \\
\text { tadas } \\
(n=41)\end{array}$ & $\begin{array}{l}\text { Densidade } \\
\text { Desejável† }\end{array}$ \\
\hline $\begin{array}{l}\text { Proteína } \\
\text { (g/100kcal) }\end{array}$ & 3,72 & 2,89 & 1,00 & 3,40 & 3,44 & 1,00 & 3,63 & 3,49 & 0,9 \\
\hline $\begin{array}{l}\text { Tiamina } \\
\text { (mg/100kcal) }\end{array}$ & 0,03 & 0,05 & 0,08 & 0,05 & 0,04 & 0,06 & 0,04 & 0,04 & 0,07 \\
\hline $\begin{array}{l}\text { Niacina } \\
\text { (mg/100kcal) }\end{array}$ & 0,35 & 0,32 & 1,50 & 0,33 & 0,43 & 1,00 & 0,39 & 0,68 & 0,90 \\
\hline $\begin{array}{l}\text { Riboflavina } \\
\text { (mg/100kcal) }\end{array}$ & 0,12 & 0,08 & 0,08 & 0,12 & 0,06 & 0,06 & 0,11 & 0,07 & 0,06 \\
\hline $\begin{array}{l}\text { Vitamina } B_{6} \\
\text { (mg/100kcal) }\end{array}$ & 0,05 & 0,07 & 0,12 & 0,08 & 0,07 & 0,08 & 0,06 & 0,08 & 0,08 \\
\hline $\begin{array}{l}\text { Ácido fólico } \\
\text { ( } \mu \mathrm{g} / 100 \mathrm{kcal})\end{array}$ & 8,00 & 9,17 & 11,00 & 11,74 & 12,51 & 9,00 & 11,88 & 12,44 & 21,00 \\
\hline $\begin{array}{l}\text { Vitamina A } \\
\text { (RE/100kcal) }\end{array}$ & 34,59 & 44,76 & 31,00 & 62,73 & 28,48 & 30,00 & 40,79 & 30,74 & 23,00 \\
\hline $\begin{array}{l}\text { Vitamina C } \\
\text { (mg/100kcal) }\end{array}$ & 1,45 & 2,75 & 1,50 & 2,48 & 2,93 & 1,70 & 2,47 & 2,76 & 1,50 \\
\hline $\begin{array}{l}\text { Cálcio } \\
\text { (mg/100kcal) }\end{array}$ & 94,01 & 46,65 & 105,00 & 91,44 & 47,91 & 74,00 & 74,79 & 52,50 & 63,00 \\
\hline $\begin{array}{l}\text { Ferro } \\
\text { (mg/100kcal) }\end{array}$ & 0,39 & 0,33 & 4,50 & 0,46 & 0,53 & 3,00 & 0,43 & 0,54 & 1,00 \\
\hline $\begin{array}{l}\text { Zinco } \\
\text { (mg/100kcal) }\end{array}$ & 0,44 & 0,37 & 1,60 & 0,50 & 0,44 & 1,10 & 0,46 & 0,43 & 0,60 \\
\hline
\end{tabular}

t: WHO 2002. 
Os alimentos que mais contribuem com o aporte de energia e nutrientes são apresentados na Tabela 7. Com exceção da vitamina $C$ e do ferro os laticínios contribuem com grande aporte de todos os outros nutrientes e energia e em todos os grupos etários. As hortaliças só aparecem no fornecimento de vitamina A e as frutas no de vitamina C. O grupo de alimentos que mais colabora com a ingestão de ferro desta população são os "Espessantes" (utilizados para fazer mingau). Neste grupo, os alimentos mais frequentes são fortificados com vitaminas e minerais e corresponderam a cerca de $80 \%$ de todos os espessantes utilizados. A carne vermelha só é encontrada no grupo dos 12 aos 24 meses contribuindo para as ingestões de proteína e de zinco.

O açúcar de adição não atingiu a contribuição de $15 \%$ nas calorias totais da dieta, mas foi uma fonte importante de energia para esta população. Dos 6 aos 8 meses o açúcar contribui com 6,3\% da energia total, este valor se mantém dos 9 aos 11 meses e aumenta para 8,4\% entre as crianças de 12 a 24 meses.

Uma análise complementar da ingestão de proteína, ferro e zinco pode ser observada na Tabela 8. Ressalta-se que a mediana de consumo de proteína proveniente das carnes entre crianças de 6 a 11 meses foi igual a zero. Quanto ao consumo do total de crianças estudadas observou-se que 1,5\% de toda a proteína animal era proveniente de carnes e $1,2 \%$ de todo o ferro vinha das carnes (ferro heme). 
Tabela 7. Grupos de alimentos que contribuem com no mínimo $15 \%$ da ingestão total de energia e nutrientes segundo grupo etário. Acrelândia, Acre, 2007

\begin{tabular}{|c|c|c|c|c|c|c|c|c|}
\hline $\begin{array}{l}\text { Grupos } \\
\text { etários }\end{array}$ & Energia & Proteína & Vitamina A & Vitamina C & Cálcio & Ácido fólico & Ferro & Zinco \\
\hline $\begin{array}{l}6 \text { a } 8 \\
\text { meses } \\
(n=27)\end{array}$ & $\begin{array}{l}\text { Laticínios }(32,4 \%), \\
\text { Leite Materno }(23,7 \%)\end{array}$ & $\begin{array}{l}\text { Laticínios } \\
(51,3 \%)\end{array}$ & $\begin{array}{c}\text { Hortaliças } \\
(37,9 \%), \\
\text { Laticínios } \\
(26,6 \%), \\
\text { Leite materno } \\
(28,8 \%)\end{array}$ & $\begin{array}{c}\text { Frutas }(55,2 \%), \\
\text { Leite Materno }(26,7 \%)\end{array}$ & $\begin{array}{l}\text { Laticínios } \\
(75,5 \%)\end{array}$ & $\begin{array}{c}\text { Espessantes } \\
(22,0 \%), \\
\text { Feijão } \\
(15,5 \%), \\
\text { Laticínios } \\
(23,7 \%), \\
\text { Leite Materno } \\
(16,6 \%)\end{array}$ & $\begin{array}{l}\text { Espessantes } \\
(37,7 \%), \\
\text { Laticínios } \\
(15,6 \%)\end{array}$ & $\begin{array}{c}\text { Laticínios } \\
(47,3 \%), \\
\text { Leite } \\
\text { materno } \\
(16,7 \%)\end{array}$ \\
\hline $\begin{array}{l}9 \text { a } 11 \\
\text { meses } \\
(n=31)\end{array}$ & $\begin{array}{l}\text { Laticínios }(21,2 \%), \\
\text { Leite materno }(21,7)\end{array}$ & $\begin{array}{l}\text { Laticínios } \\
(36,7 \%)\end{array}$ & $\begin{array}{l}\text { Hortaliças } \\
(45,5 \%), \\
\text { Laticínios } \\
(15,5 \%), \\
\text { Leite materno } \\
(25,5 \%)\end{array}$ & $\begin{array}{l}\text { Frutas }(36,4 \%), \\
\text { Leite Materno }(28,1 \%), \\
\text { Cereais/Tubérculos/ } \\
\text { Massas }(18,8 \%)\end{array}$ & $\begin{array}{l}\text { Laticínios } \\
(60,2 \%)\end{array}$ & $\begin{array}{c}\text { Feijão } \\
(27,3 \%), \\
\text { Laticínios } \\
(15,0 \%)\end{array}$ & $\begin{array}{c}\text { Espessantes } \\
(18,1 \%), \\
\text { Feijão } \\
(16,4 \%), \\
\text { Fórmula } \\
\text { infantil } \\
(16,4 \%)\end{array}$ & $\begin{array}{c}\text { Laticínios } \\
(34,1 \%)\end{array}$ \\
\hline $\begin{array}{l}12 \text { a } 24 \\
\text { meses } \\
(n=108)\end{array}$ & $\begin{array}{c}\text { Laticínios }(27 \%), \\
\text { Cereais/Tubérculos/Massas } \\
(17,9 \%)\end{array}$ & $\begin{array}{c}\text { Laticínios } \\
(39,6 \%), \\
\text { Carne } \\
\text { vermelha } \\
(18,6 \%)\end{array}$ & $\begin{array}{l}\text { Hortaliças } \\
(37,5 \%), \\
\text { Laticínios } \\
(29,2 \%)\end{array}$ & $\begin{array}{l}\text { Frutas }(47,0 \%), \\
\text { Cereais/Tubérculos/ } \\
\text { Massas }(26,2 \%)\end{array}$ & $\begin{array}{l}\text { Laticínios } \\
(77,9 \%)\end{array}$ & $\begin{array}{c}\text { Espessantes } \\
(15,0 \%), \\
\text { Feijão } \\
(31,3 \%), \\
\text { Laticínios } \\
(17,9 \%)\end{array}$ & $\begin{array}{c}\text { Espessantes } \\
(18,4 \%), \\
\text { Feijão }(18,8 \%)\end{array}$ & $\begin{array}{c}\text { Laticínios } \\
(38,3 \%), \\
\text { Carne } \\
\text { vermelha } \\
(23 \%)\end{array}$ \\
\hline $\begin{array}{l}\text { Total } \\
(n=166)\end{array}$ & $\begin{array}{l}\text { Laticínios }(26,1 \%) \\
\text { Leite materno }(15,4 \%)\end{array}$ & $\begin{array}{c}\text { Laticínios } \\
(40,9 \%), \\
\text { Carne } \\
\text { vermelha } \\
(15,3 \%)\end{array}$ & $\begin{array}{l}\text { Hortaliças } \\
(35,9 \%), \\
\text { Laticínios } \\
(25,0 \%), \\
\text { Leite materno } \\
(22,2 \%)\end{array}$ & $\begin{array}{l}\text { Frutas }(44,5 \%), \\
\text { Leite Materno }(22,4 \%), \\
\text { Cereais/Tubérculos/ } \\
\text { Massas }(19,2 \%)\end{array}$ & $\begin{array}{l}\text { Laticínios } \\
(72,7 \%)\end{array}$ & $\begin{array}{c}\text { Espessantes } \\
(16,0 \%), \\
\text { Feijão } \\
(27,2 \%), \\
\text { Laticínios } \\
(17,9 \%)\end{array}$ & $\begin{array}{c}\text { Espessantes } \\
(20,8 \%), \\
\text { Feijão }(17,5 \%)\end{array}$ & $\begin{array}{c}\text { Laticínios } \\
(38,6 \%), \\
\text { Carne } \\
\text { vermelha } \\
(18,6 \%)\end{array}$ \\
\hline
\end{tabular}


Tabela 8. Ingestão mediana (intervalo interquartil) de nutrientes por grupo etário. Acrelândia, Acre, 2007.

\begin{tabular}{|c|c|c|c|}
\hline Nutrientes & $\begin{array}{c}6 \text { a } 8 \text { meses } \\
(n=27)\end{array}$ & $\begin{array}{c}9 \text { a } 11 \text { meses } \\
(n=31)\end{array}$ & $\begin{array}{c}12 \text { a } 24 \\
\text { meses } \\
(n=108)\end{array}$ \\
\hline Proteína total (g) & $\begin{array}{c}22,20 \\
(9,20 ; 38,90)\end{array}$ & $\begin{array}{c}26,10 \\
(19,7 ; 39,5)\end{array}$ & $\begin{array}{c}38,35 \\
(24,82 ; 54,22)\end{array}$ \\
\hline Proteína de origem animal (g) & $\begin{array}{c}14,00 \\
(5,00 ; 33,00)\end{array}$ & $\begin{array}{c}18,00 \\
(10,3 ; 25,90)\end{array}$ & $\begin{array}{c}27,30 \\
(14,40 ; 37,67)\end{array}$ \\
\hline Proteína de carnes† ${ }^{\dagger}(\mathrm{g})$ & $\begin{array}{c}0,00 \\
(0,00 ; 2,60)\end{array}$ & $\begin{array}{c}0,00 \\
(0,00 ; 8,10)\end{array}$ & $\begin{array}{c}5,00 \\
(0,00 ; 12,57)\end{array}$ \\
\hline Ferro total (mg) & $\begin{array}{c}1,58 \\
(0,44 ; 3,80)\end{array}$ & $\begin{array}{c}3,15 \\
(2,06 ; 6,17)\end{array}$ & $\begin{array}{c}5,10 \\
(3,15 ; 7,17)\end{array}$ \\
\hline Ferro de carnes $\dagger(\mathbf{m g})$ & $\begin{array}{c}0,00 \\
(0,00 ; 0,14)\end{array}$ & $\begin{array}{c}0,00 \\
(0,00 ; 0,57)\end{array}$ & $\begin{array}{c}0,34 \\
(0,00 ; 0,82)\end{array}$ \\
\hline Ferro biodisponível (mg) & $\begin{array}{c}0,13 \\
(0,05 ; 0,26)\end{array}$ & $\begin{array}{c}0,32 \\
(0,14 ; 0,43)\end{array}$ & $\begin{array}{c}0,41 \\
(0,25 ; 0,65)\end{array}$ \\
\hline $\begin{array}{l}\text { Biodisponibilidade } \\
\text { De ferro na dieta }(\%)\end{array}$ & $\begin{array}{c}8,13 \\
(4,80 ; 10,00)\end{array}$ & $\begin{array}{c}8,24 \\
(6,06 ; 10,88)\end{array}$ & $\begin{array}{c}8,88 \\
(6,29 ; 10,74)\end{array}$ \\
\hline Zinco total (mg) & $\begin{array}{c}3,16 \\
(1,59 ; 5,34)\end{array}$ & $\begin{array}{c}3,47 \\
(2,87 ; 5,19)\end{array}$ & $\begin{array}{c}5,09 \\
(3,07 ; 7,23)\end{array}$ \\
\hline Zinco biodisponível (mg) & $\begin{array}{c}1,20 \\
(0,56 ; 2,05)\end{array}$ & $\begin{array}{c}1,37 \\
(0,80 ; 1,80)\end{array}$ & $\begin{array}{c}1,86 \\
(0,93 ; 2,53)\end{array}$ \\
\hline $\begin{array}{l}\text { Biodisponibilidade } \\
\text { De zinco na dieta (\%) }\end{array}$ & $\begin{array}{c}43,40 \\
(35,22 ; 46,38)\end{array}$ & $\begin{array}{c}36,82 \\
(31,00 ; 42,36)\end{array}$ & $\begin{array}{c}35,42 \\
(29,17 ; 40,00)\end{array}$ \\
\hline
\end{tabular}

Foi possível verificar que 78,3\% das crianças de 6 a 24 meses possuem dietas com biodisponibilidade de ferro entre "Muito baixa" e "Baixa". Na faixa etária dos 6 aos 8 meses essa proporção é de 85,2\%, entre os 9 e 11 meses é de 77,4\% e dos 12 aos 24 meses é de 76,9\%. 


\section{DISCUSSÃO}

O objetivo deste estudo foi descrever o estado nutricional e as práticas alimentares de crianças menores de 24 meses de um município da Amazônia Ocidental Brasileira. As inadequações dietéticas encontradas situam a população de estudo em risco nutricional e poderão servir de subsídio para o desenvolvimento de estratégias específicas para adequar a qualidade nutricional e as práticas alimentares na infância.

Antes de discutir os resultados, é importante considerar algumas limitações deste trabalho. Por se tratar de estudo de delineamento transversal, não foi possível identificar o tempo de exposição aos fatores dietéticos de risco ou de proteção para o estado nutricional encontrado; deste modo, o efeito causal das exposições de interesse sobre os indicadores bioquímicos ou antropométricos atuais não pôde ser avaliado. Na faixa etária de estudo, a dieta muda rapidamente e a avaliação de consumo alimentar em um único período de tempo não reflete necessariamente o consumo habitual em diferentes fases de transição da dieta. Outra limitação se refere ao número de observações, devido ao reduzido número de habitantes do município. Além disso, praticamente todas as crianças vinham de famílias de baixa renda, com precárias condições de moradia e de saneamento básico, ou seja, não havia diferenças marcantes entre elas. Uma possível variação sazonal na alimentação não pôde ser avaliada, uma vez que o inquérito foi realizado com praticamente todas as crianças durante o mesmo mês. É provável que a diversidade da dieta nesta população seja determinada pela sazonalidade, devido ao precário abastecimento de alimentos no município. 


\subsection{CARACTERIZAÇÃO DA POPULAÇÃO DE ESTUDO}

Não foram encontradas diferenças estatisticamente significantes entre as crianças que completaram o histórico alimentar e as que não completaram. O perfil das duas populações se mostrou semelhante no que se refere ao número de crianças nos grupos etários, sexo e indicadores nutricionais.

Em nosso estudo, a distribuição da população por sexo e por grupo etário foi homogênea, não havendo maior concentração de crianças em nenhum dos grupos. A faixa etária dos 12 aos 24 meses concentrou a maior parte das crianças, já que compreendia um intervalo de 12 meses de idade $(n=108)$. As faixas etárias de 6 a 8 meses e de 9 a 11 meses possuem por volta de 30 crianças cada devido ao intervalo de idade ser apenas de 3 meses. Os anos de escolaridade materna e a paterna tiveram o mesmo valor médio ( 7,1 anos), o que contrasta com os dados nacionais publicados sobre a PNDS de 2006 (MS 2008), onde as mulheres alcançaram proporcionalmente maiores anos de estudo que os homens. A proporção de mães adolescentes foi de $17,5 \%$, semelhante ao encontrado em Pelotas, de 18,7\% (MOTA e BARROS 2008).

Segundo a OMS (WHO 2009) 95\% das mães adolescentes vivem em países em desenvolvimento. A gravidez na adolescência representa risco para a mãe e para o bebê, além de prejuízos econômicos. A mãe adolescente tem menos acesso

à escolaridade e às melhores oportunidades de emprego, e menos auto-estima. É perpetuado um ciclo de pobreza, morbidade e baixas condições socioeconômicas e de saúde.

A presença dos pais ou de pelo menos um deles no domicílio pode colocar a criança ou jovem em menor situação de vulnerabilidade diante da pobreza ou de 
situações de agravos em saúde. Em nossa população de estudo, a prevalência de crianças menores de 2 anos que moravam com ambos os pais foi de $71,7 \%$, mostrando maior desagregação familiar em relação a $81,2 \%$ encontrados no país na última Pesquisa Nacional de Demografia e Saúde (MS 2008).

HEATON e col (2005) colocaram o contexto familiar como determinante em destaque para a saúde da criança nos países em desenvolvimento, em especial a educação materna e a renda familiar. Outros fatores importantes são o intervalo interpartal e o acesso aos serviços de saúde. As práticas alimentares e de cuidados com a criança são influenciadas por todos estes fatores.

No presente estudo, o abastecimento de água pela rede geral esteve presente em 59\% dos domicílios. Na PNDS de 2006 foi encontrado que 90,9\% dos domicílios brasileiros na região urbana possuíam abastecimento de água pela rede geral. O município de Acrelândia foi criado em 1993, e as obras de infra-estrutura básica ainda não foram concluídas. A maioria dos domicílios onde o abastecimento pela rede geral não ocorria, a captação de água era realizada a partir dos poços, prática referida em $40 \%$ dos domicílios. Visto que a grande maioria dos domićlios não possui rede coletora de esgoto e os dejetos são escoados por fossas, há grande possibilidade de contaminação da água por material fecal e transmissão de doenças diarréicas.

A participação no Programa Bolsa Família em Acrelândia foi surpreendentemente baixa (11\%), já que a maioria das famílias é de baixa renda, possivelmente com rendimento inferior ao teto mínimo estabelecido para serem beneficiárias do Programa Bolsa Família (MDS, Brasil). O Ministério do Desenvolvimento Social disponibiliza na internet o número de famílias beneficiárias do programa, onde há a informação de que 966 famílias do município de Acrelândia 
são beneficiárias (MDS 2009). Pode ter ocorrido omissão de informação por parte dos entrevistados, talvez por receio de perder o benefício.

\subsection{MORBIDADES E ESTADO NUTRICIONAL}

No presente estudo, a proporção de crianças que nasceram com baixo peso foi de $7,2 \%$ e se mostrou condizente com média nacional $(8,02 \%)$ segundo dados do DATASUS (2009). O número de crianças que apresentaram parasitas intestinais foi alto em todos os grupos etários. Em inquérito realizado no município de São Paulo foi encontrado que a prevalência de enteroparasitoses variou intensamente com a idade da criança, apresentando tendência ascendente até o terceiro ano de vida (FERREIRA e col 2000). No entanto, isso não ocorreu com a população deste estudo, cujas prevalências se mantiveram constantes com o avançar da idade, apresentando valor médio de $25,5 \%$.

A presença de diarréia referida nos últimos 15 dias também se mostrou constantemente alta em todos os grupo etários aqui estudados, com prevalência de 45,7\%. A pesquisa realizada na mesma região em 2003 com crianças da mesma faixa etária revelou a prevalência de $39,1 \%$ de diarréia recente (CASTRO e col 2009). Dados do município de São Paulo contrastam com estas altas prevalências. 0

inquérito realizado em 1996 mostrou que a prevalência de diarréia nos últimos 15 dias anteriores à pesquisa foi de 9,0\% para crianças de 6 a 12 meses e 6,8\% de 12 a 24 meses, além de apresentar redução estatisticamente significante com a idade (BENÍCIO e MONTEIRO 2000). Em Pernambuco LIRA e col (2003) também encontraram incidência de diarréia pouco expressiva entre crianças menores de 12 meses, com mediana de 2 episódios/criança/ano. 
A prevalência de anemia em todas as crianças avaliadas em nosso estudo foi de 40,0\%, revelando-se um grave problema de saúde pública (WHO 2001). Este resultado se mostrou maior que no inquérito realizado em 2003 nos municípios de Acrelândia e Assis-Brasil, onde CASTRO e col (2009) encontraram prevalência de 33,3\% para esta faixa etária. Resultados semelhantes foram revelados em estudo transversal com crianças mexicanas entre 12 e 23 meses, onde 41,4\% delas estavam anêmicas (RODRÍGUEZ e col 2007). Porém, comparando-se com outros estudos brasileiros, os resultados parecem ser menos expressivos. VITOLO e BORTOLINI (2007) estudaram crianças gaúchas de 12 a 16 meses de idade e encontraram prevalência de anemia de $63,7 \%$, achado semelhante ao de SPINELLI e col (2005), que estudaram crianças entre 6 e 12 meses de idade residentes nas 5 regiões do Brasil e identificaram a prevalência de $65,4 \%$ de anemia.

A baixa ocorrência da prática de aleitamento materno exclusivo até o sexto mês de idade explica, em parte, a alta prevalência de deficiência de ferro observada em nosso estudo. Além disso, apesar de não ter sido investigada no presente estudo, a anemia na gestação também pode ser uma causa de baixas reservas de ferro das crianças (PEE e col 2002; COLOMER e col 1990). Ambos os problemas ocorrendo simultaneamente podem resultar na alta prevalência de deficiência de ferro encontrada nas crianças de 6 a 8 meses. Este padrão aliado à dieta com baixa porcentagem de ferro biodisponível, praticada pela grande maioria das crianças, perpetua a alta ocorrência de deficiência de ferro até os 2 anos de idade.

Condizente com a literatura (KRAEMER e ZIMMERMANN 2007), a maioria (95\%) dos casos de anemia observados em Acrelândia foi devido à deficiência de ferro, totalizando $38,1 \%$ das crianças com anemia ferropriva. Já CASTRO e col (2009) encontraram apenas $70 \%$ dos casos de anemia devido à deficiência de ferro 
em crianças de 6 a 24 meses da Amazônia Ocidental Brasileira, estando presente em $28 \%$ da população.

Segundo a OMS (WHO 2008), os principais fatores de risco para a anemia ferropriva incluem baixa ingestão de ferro, baixa absorção de ferro a partir de dietas ricas em fitatos ou compostos fenólicos, e períodos da vida onde as necessidades de ferro são especialmente altas, como na infância. Nossa população de estudo reúne todos estes componentes, o que explica essa alta proporção de anemia ferropriva.

A deficiência de ferro isolada, ou seja, sem anemia, foi encontrada em nosso estudo em 44,2\% das crianças. Esta prevalência foi constante nos três grupos etários, sendo assim, as crianças de 6 a 8 meses já apresentavam alta proporção de 45,5\% de deficiência de ferro. As proporções de crianças com estes distúrbios se mostraram constantemente altas desde os 6 meses de idade. Diferente do que foi encontrado por CASTRO e col (2009), em que a deficiência de ferro foi maior nas crianças de 12 a 24 meses chegando a 74\%. No entanto, nossos resultados devem ser cuidadosamente interpretados. Tem sido pautada na literatura a necessidade de reavaliar os critérios laboratoriais para deficiência de ferro e anemia ferropriva em crianças menores de 2 anos. Os pontos de corte para ferritina e receptor de transferrina são extrapolados para outros grupos etários e parecem não ser apropriados para crianças pequenas (DOMELLÖF e col 2002).

KRAMER e ZIMMERMANN (2007) comentam que o risco de deficiência de ferro na infância é alto porque somente por volta de $50 \%$ do ferro necessário para crianças de 6 meses de idade pode ser fornecido pelo leite materno, e nessa idade as reservas conseguidas até o nascimento têm grandes chances de já terem sido utilizadas para dar suporte para as funções normais e o crescimento. Se a mãe foi anêmica na gestação, os estoques são depletados muito antes. Continuar somente 
com o aleitamento materno vai suprir apenas metade das necessidades de ferro das crianças, a outra metade deve vir dos alimentos complementares ou um suplemento de ferro deve ser utilizado se deseja-se evitar a anemia ferropriva.

Os resultados antropométricos do presente estudo revelam que a prevalência de stunting (12,3\%) foi ligeiramente maior que em 2003 (11,5\%) no estudo transversal desenvolvido por CASTRO e col (2009) na mesma região. Em comparação com a última PNDS observa-se que a população de estudo tem maior prevalência de déficit de altura/idade que a distribuição nacional (MS 2008). No primeiro ano de vida, as crianças brasileiras apresentaram 4,9\% de prevalência desse déficit e nosso estudo encontrou 9,3\%. Já no segundo ano $12,3 \%$ das crianças brasileiras tinham déficits de altura/idade segundo a PNDS, enquanto que nosso estudo apresentou a proporção de 13,9\%.

No presente estudo, a deficiência de vitamina A, avaliada pela concentração de retinol sérico menor que $0,7 \mu \mathrm{mol} / \mathrm{L}$, foi observada em $14,9 \%$ das crianças, revelando-se problema moderado de saúde pública (WHO 2009b). Medir a concentração de retinol sérico de populações constitui um dos métodos mais praticados para avaliar o estado nutricional de vitamina A (WHO 2009b). No entanto, o retinol sérico sofre influência do controle homeostático, portanto, reflete o estado nutricional de vitamina A apenas quando as reservas corporais estão muito elevadas ou muito baixas (WHO 1996). Além disso, os níveis séricos de retinol podem apresentar alterações nos processos inflamatórios e infecciosos (WHO 1996). As interpretações desses resultados devem ser feitas com cautela.

Embora exista forte evidência de associações entre a deficiência de vitamina A e a anemia, o mecanismo bioquímico ainda é obscuro. A anemia causada pela deficiência de vitamina A assemelha-se à anemia hipocrômica. Diferente da anemia 
ferropriva, os níveis de ferritina na deficiência de vitamina A são normais. (BLOEM 1995)

A principal causa de deficiência de vitamina A como problema de saúde pública é uma dieta cronicamente insuficiente em vitamina $A$ que pode levar à baixos estoques corporais e não atender as necessidades fisiológicas (WHO 2009b).

Não existem limites de referência padronizados para níveis séricos de ácido fólico e vitamina $B_{12}$ de crianças pequenas, portanto, é difícil interpretar os resultados. De acordo com os pontos de corte estabelecidos para este estudo $(6,8$ nmol/L para ácido fólico e $148 \mathrm{pmol} / \mathrm{L}$ para vitamina $\mathrm{B}_{12}$ ) foi encontrada a prevalência de $2 \%$ de deficiência de ácido fólico e de $12 \%$ de vitamina $B_{12}$. Também se observou que a concentração sérica média de vitamina $B_{12}$ das crianças de 9 a 11 meses foi menor $(p=0,017)$ que o das crianças de 12 a 24 meses.

As concentrações séricas de vitamina $B_{12}$ mudam acentuadamente no primeiro ano de vida. Crianças amamentadas têm menores níveis séricos de vitamina $B_{12}$ que as crianças não amamentadas, o que pode estar relacionado aos menores conteúdos de vitamina $B_{12}$ no leite materno do que nos alimentos substitutos (TANEJA e col 2007; HAY e col 2008).

GARCÍA-CASAL e col (2005), em inquérito nacional na Venezuela, encontraram 31\% e 36\% de deficiência de ácido fólico (ponto de corte de $3 \mathrm{ng} / \mathrm{L}$ ) e $16 \%$ e $10 \%$ de deficiência de vitamina $B_{12}$ (ponto de corte de $200 \mathrm{pg} / \mathrm{mL}$ ) nas crianças menores de 1 ano de idade e de 2 a 4 anos, respectivamente. Já TANEJA e col (2007) encontraram $28 \%$ das crianças de 6 a 30 meses com concentrações menores que 150 pmol/L e 15\% com concentrações de ácido fólico menores que 5 
nmol/L. Esses achados revelaram prevalências mais expressivas que em nosso estudo.

TANEJA e col (2007), em estudo transversal de base populacional com crianças indianas de 6 a 30 meses, mostraram que a concentração mediana (P25; P75) de vitamina $B_{12}$ de crianças amamentadas de 6 a 11 meses foi de 183,8 pmol/L $(120 ; 263)$ e das não amamentadas de mesma idade foi de 334,0 pmol/L (234; 463). Em nosso estudo a concentração nas crianças de 6 a 11 meses foi de 191,0 pmol/L (173; 274). Já a concentração das crianças indianas amamentadas de 12 a 24 meses foi de $171,6 \mathrm{pmol} / \mathrm{L}(120 ; 250)$ e das não amamentadas foi 284,5 pmol/L (212; 381), enquanto que as crianças amamentadas e não amamentadas de mesma idade de nossa população de estudo apresentaram 252,0 pmol/L (189; 317). É importante ressaltar que a maioria das famílias incluídas no estudo de TANEJA e col era vegetariana; portanto, espera-se que as concentrações de vitamina $B_{12}$ sejam baixas, mas, apesar de nossa população não ser vegetariana, as concentrações foram muito semelhantes.

De fato, VILLAMOR e col (2008) encontraram forte associação positiva entre quartis de consumo mediano de proteína animal, especialmente da carne e do leite, com concentrações séricas de vitamina $B_{12}$ em crianças de idade escolar da Colômbia. Também foi observada associação de indicadores socioeconômicos, como a quantidade de dinheiro destinada à comida no domicílio, com o consumo de proteína animal, confirmando a hipótese de que a carne é um item caro e que seu baixo consumo está relacionado com a menor disponibilidade de renda.

HAY e col (2008) observaram em estudo longitudinal com crianças norueguesas que o ácido fólico sérico é alto do nascimento até os 6 meses de idade, quando então declina e aos 24 meses atinge concentrações de até 50\% dos 
valores do nascimento. A vitamina $B_{12}$ sérica total diminui do nascimento aos 6 meses e então, gradualmente aumenta. Os autores encontraram que a concentração de ácido fólico sérico é similar em crianças amamentadas e não amamentadas, mas as crianças que foram amamentadas exclusivamente tiveram as maiores concentrações e o ácido fólico sérico esteve associado positivamente com a o aleitamento materno exclusivo. Enquanto que TANEJA e col (2007) encontraram que as concentrações séricas de ácido fólico eram maiores em crianças amamentadas no momento do estudo.

Em relação ao ácido fólico TANEJA e col (2007) encontraram concentração mediana (P25; P75) nas crianças de 6 a 11 meses amamentadas de 20,5 nmol/L $(11,7 ; 34,4)$ e não amamentadas de 5,3 nmol/L $(3,4 ; 7,7)$. Já nas crianças de 12 a 24 meses amamentadas foi de $11,9 \mathrm{nmol} / \mathrm{L}(7,9 ; 18,9)$ e nas não amamentadas de 5,8 nmol/L (4,3; 8,2). Em nosso estudo foi encontrada a concentração sérica mediana de ácido fólico de $25 \mathrm{nmol} / \mathrm{L}(17,7 ; 35,8)$ nas crianças de 6 a 11 meses a concentração e de 21,65 nmol/L $(17,1 ; 33,4)$ nas crianças de 12 a 24 meses.

\subsection{PRÁTICAS ALIMENTARES}

No presente estudo, o início da amamentação ocorreu em quase a totalidade das crianças (99\%). Das crianças menores de 6 meses, 96,6\% ainda estavam em aleitamento materno, o que revela ser resultado melhor que o encontrado por NEJAR e col (2004) com crianças de Campinas (82,2\%) e por WAYLAND (2004) em Rio Branco, de 55\%. Em outro estudo com 180 famílias aleatoriamente selecionadas de um bairro periférico da capital do Acre, Rio Branco, WAYLAND (2004) encontrou 
o início do aleitamento materno em $96 \%$, assim como foi descrito na última PNDS em relação ao país, 96,4\% (MS 2008).

A prática do aleitamento materno exclusivo até $06^{\circ}$ mês foi referida por $9,64 \%$ das crianças estudadas, o que é inferior a outros achados brasileiros. Em estudo anterior com crianças menores de 2 anos realizado em Acrelândia e AssisBrasil, municípios do Acre, CASTRO e col (2009) encontraram prática do aleitamento materno exclusivo até os 6 meses em 16,2\% das crianças. NEJAR e col (2004) encontraram a proporção de 27,1\% e a PNDS 2006 (MS 2008) encontrou 39,8\% em relação ao Brasil.

Em nosso estudo, a frequência de consumo de leite materno apresentou diferença estatisticamente significante entre os grupos etários, evidenciando queda expressiva no segundo ano de vida. Resultado semelhante foi observado em relação à frequência de consumo de leite de vaca, porém o que se apresenta é o aumento significativo no segundo ano de vida.

O aleitamento misto, ou seja, o consumo de leite materno e leite de vaca simultaneamente, foi observado em 38,9\% das crianças deste estudo. Esse resultado se mostrou mais expressivo do que VIEIRA e col (2003) encontraram com as crianças de Campinas de 1 ano de idade: de 19,5\% a 23,8\%. ASSIS e col (2004) observaram a prevalência de $30,1 \%$ com as crianças de Salvador. Já ANDERSON e col (2008), encontraram a proporção de $50 \%$ das crianças do Camboja recebendo leite materno e leite de vaca. Nos Estados Unidos, DEE e col (2008) estudaram crianças amamentadas de 3 a 10,5 meses e observaram que no primeiro mês de vida $39,4 \%$ já consumiam leite materno e fórmula infantil. 
Na prática do aleitamento misto é possível observar em nossa população de estudo consumo excessivo de leite (soma do leite materno e do leite de vaca) e, consequentemente, o consumo insuficiente de outros alimentos. $O$ leite pode substituir ou complementar refeições principais, prejudicando o aporte de nutrientes e a formação de hábitos alimentares saudáveis. Além disso, a introdução do leite de vaca pode contribuir para o desmame completo. DANG e col (2005), em estudo transversal com crianças menores de 36 meses do Tibete, encontraram associação entre o tempo total de duração do aleitamento materno e a idade de introdução de leite de vaca (fluido ou em pó). No presente estudo observou-se que o consumo de leite de vaca é alto já no primeiro grupo etário e aumenta conforme a idade, chegando a $98,1 \%$ nas crianças de 12 a 24 meses.

Segundo as recomendações dos "10 passos para uma alimentação saudável - Guia alimentar para crianças menores de 2 anos" (MS 2002) as consistências das dietas foram avaliadas. O Guia recomenda que a consistência evolua de acordo com a idade iniciando-se com alimentos amassados e consistentes, depois triturados, picados e, por último, com a consistência da dieta da família. Neste estudo foi observado $61,4 \%$ das crianças consumindo alimentos menos consistentes que 0 recomendado, proporção maior que a encontrada por AGGARWAL (2008), que encontrou 38\%. Segundo a distribuição apresentada, observa-se que as crianças começam a introdução com alimentos pastosos, mas não evoluem de maneira progressiva, permanecendo com a ingestão de alimentos líquidos e pastosos por um tempo maior que o recomendado. Desta forma, existem mais crianças com inadequações na consistência dos alimentos complementares nas maiores faixas etárias. Esse fato é preocupante, pois quanto mais pastosa ou líquida a consistência do alimento menor sua densidade energética e nutricional. 
Em nosso estudo, com relação à baixa proporção de crianças que tinham o consumo habitual de pelo menos uma porção de fruta $(48,2 \%)$, é possível observar resultados diferentes em relação a alguns estudos brasileiros. Em Campinas, VIEIRA e col (2003) encontraram que $65,6 \%$ a $73,2 \%$ das crianças ingeriam frutas diariamente. SALDIVA e col (2007) encontraram que 87\% das crianças de 6 a 12 meses do estado de São Paulo consumiram frutas por meio de recordatório de 24 horas. Comparando nosso resultado com estudos internacionais observam-se dois extremos. BREKKE e col (2007) encontraram o consumo diário de frutas por $66 \%$ a 72,7\% das crianças de 1 ano de idade da Suíça. Já FABER e col (2004) encontrou que menos de $10 \%$ da população de 4 a 24 meses de uma comunidade da África do Sul consumiam frutas.

Em nosso estudo, houve diferença estatisticamente significante em relação à proporção de crianças que consumiam pelo menos uma porção de fruta. Ou seja, essa proporção se torna realmente maior (60\%) somente no $2^{\circ}$ ano de vida, quando a recomendação é de que no $6^{\circ}$ mês a criança já receba 2 porções de frutas por dia (MS 2002). Observamos, também, baixo consumo habitual de hortaliças (53,4\%), assim como ANDERSON e col (2008) e OSÓRIO e col (2004) também observaram em seus estudos.

É importante destacar o padrão de consumo de mingau entre as crianças estudadas, que aumentou com a idade, quando deveria diminuir.

DEE e col (2008) estudando crianças americanas até 10,5 meses de idade encontraram que o consumo de cereais infantis (espessantes) se inicia no primeiro mês de vida. Aos 6 meses é de 79\% aumentando para 83\% por volta dos 8 meses e caindo para $68 \%$ aos 10,5 meses. 
MICHAELSEN e FRIIS (1998) comentaram que um dos principais problemas nutricionais na primeira infância é a inadequação nutricional dos alimentos complementares, que consistem tipicamente de mingaus feitos com cereais. $\mathrm{O}$ problema de dietas baseadas em mingau é a baixa densidade de nutrientes e o alto conteúdo de fatores antinutricionais, diminuindo a absorção do ferro não-heme e do zinco. Além disso, o conteúdo de componentes que potencializam a absorção de ferro não-heme, como a vitamina C, é baixo.

Duas estratégias encontradas pela indústria de alimentos são reduzir o conteúdo de fitatos dos espessantes ou degradá-los, mas os resultados destes procedimentos ainda não se mostram eficazes. Em estudo duplo-cego em que crianças suíças de 6 a 12 meses de idade receberam espessantes com diferentes conteúdos de fitatos não foi encontrado nenhum efeito benéfico nos níveis de hemoglobina, ferritina sérica e zinco sérico quando os fitatos foram reduzidos (LIND e col 2003). HURRELL e col (2003) mensuraram a influência da degradação do ácido fítico na absorção do ferro a partir de mingaus de 9 cereais diferentes (arroz, trigo, milho, aveia, 4 tipos de sorgo e uma mistura de trigo e soja) reconstituídos com água e com leite. Os autores concluíram que a degradação dos fitatos aumenta a absorção de ferro dos mingaus preparados com água, mas não com leite.

Outro achado preocupante em nosso estudo foi o consumo crescente, segundo a idade, de alimentos não recomendados para a faixa etária nos intervalos entre as refeições principais. Investigar o conteúdo alimentar dos lanches, separadamente das refeições, fornece resultados interessantes sobre o início de padrões alimentares inadequados que podem ser mantidos em outras fases da vida. Alimentos processados ricos em sódio, conservantes, açúcar e gordura e pobre em outros nutrientes foram consumidos pelas crianças desde muito cedo. 
ZIEGLER e col (2006) observaram que mais de $25 \%$ da energia ingerida por crianças americanas de 4 a 24 meses é proveniente de lanches. Os autores também ressaltam que o consumo de bebidas açucaradas por crianças de 1 a 2 anos deve ser monitorada segundo seus conteúdos de energia, açúcar e adequação nutricional, especialmente com o aumento da obesidade infantil e do diabetes.

ZIEGLER e col (2006b), analisando o consumo alimentar de crianças americanas de 15 a 24 meses, também encontraram diversos alimentos não recomendados para a faixa etária (\% de crianças que consumiram): salgadinho (14\%), biscoitos doces recheados (26\%), refrigerantes (16\%) e doces (16\%).

Em estudo longitudinal, realizado na Suíça acompanhando crianças do nascimento até os 12 meses de idade, BREKKE e col (2007) avaliaram a frequência de consumo de alimentos com alto teor de açúcar e baixo teor de nutrientes. A proporção de crianças que consumiam estes alimentos mais de 2 vezes por semana, o que foi considerada uma frequência alta, foi de $24 \%$. Esse hábito teve associação positiva com o fato de a criança ter outros irmãos mais velhos e com características maternas: alto consumo destes alimentos durante a gravidez, ter menos de 25 anos e ser solteira. Também teve associação negativa com escolaridade dos pais. As crianças que consumiam doces frequentemente também tinham o hábito de consumir alimentos ricos em gordura e menor ingestão de frutas, hortaliças e batatas.

Consumir lanches nos intervalos é importante parte da dieta diária. Os lanches deveriam ser planejados para garantir que a criança tenha apetite na refeição principal, porém adequados aos sinais de fome e de saciedade manifestados pela criança. Opções mais nutritivas e naturais devem ser 
encorajadas, como uma oportunidade de construir preferências alimentares mais amplas para a vida (ZIEGLER e col 2006b).

Em nosso estudo, a introdução precoce (antes dos 6 meses) de alimentos pastosos foi observada em 39,1\% das crianças avaliadas. MAMABOLO e col (2004), em estudo que acompanhou crianças africanas do nascimento até os 12 meses de idade, encontraram que a introdução de alimentos pastosos foi uma prática comum, sendo que no primeiro mês de vida $45 \%$ das crianças já recebiam algum alimento deste tipo. Já GUPTA e col (2007) observaram que 62\% das crianças recebiam alimentos complementares antes dos 6 meses.

MERWE e col (2007) comentam que os países em desenvolvimento enfrentam um desafio na adequação do momento de introdução dos alimentos complementares, uma vez que a prevalência de introdução precoce é muito alta.

Por outro lado, em nosso estudo, um quinto das crianças de 6 a 8 meses (20\%) ainda não havia iniciado a alimentação pastosa. COULTHARD e col (2009) em estudo longitudinal na Inglaterra também encontraram que $18 \%$ das crianças de 6 a 9 meses ainda não tinham recebido alimentos pastosos. Os autores também observaram que as crianças que começaram a consumir estes alimentos após os 10 meses tiveram consequências aos 7 anos de idade. Elas ingeriam menos porções de hortaliças e frutas e uma variedade menor de hortaliças aos 7 anos de idade do que as crianças com introdução na idade adequada. Estes resultados suportam a idéia de que essa fase é muito importante na formação de hábitos e preferências alimentares. 


\subsection{AVALIAÇÃO DO CONSUMO ALIMENTAR}

O consumo de energia e proteínas da dieta foi adequado nas três faixas etárias, não revelando nenhum risco de déficit energético-protéico para a população de nosso estudo. No entanto, a ingestão mediana de vários micronutrientes se mostraram inferiores às recomendações. As maiores inadequações se encontraram no grupo de crianças de 6 a 8 meses, revelando a fragilidade principalmente deste grupo. Em pelo menos 2 grupos etários foram encontradas ingestões medianas abaixo das recomendações dos seguintes nutrientes: tiamina, ferro e zinco.

FABER e col (2004), em uma comunidade Sul-Africana, observou baixa ingestão mediana de niacina, ácido fólico e vitamina C por crianças de 6 a 12 meses. Já no estudo de ANDERSON e col (2008), com crianças de 6 a 36 meses do Camboja, foram encontradas ingestões abaixo das recomendações de energia, cálcio, ferro e zinco. PERLAS e col (2004), em estudo com crianças das Filipinas acompanhadas dos 10 aos 22 meses de idade, observaram déficits na ingestão mediana de energia, vitamina A, tiamina, riboflavina, niacina e vitamina C.

COWIN e col (2000) analisaram o consumo alimentar de crianças inglesas de 18 meses de idade por meio de recordatório alimentar de 3 dias. Verificaram que as ingestões de todos os nutrientes estudados estavam acima das recomendações, com exceção da vitamina $D$, ferro e zinco.

Em estudo de revisão, KREBS (2007) destaca pontos importantes sobre a alimentação complementar para que sejam atingidas as necessidades de ferro e zinco. O autor comenta que adicionar cereais à dieta pode aumentar a ingestão de zinco modestamente, milho, trigo, arroz e raízes são relativamente baixos em zinco e têm os fatores antinutricionais (fitatos) que faz com que o zinco seja menos 
biodisponível. Já as carnes e fígado têm maiores concentrações e maior biodisponibilidade de ferro e zinco que outros alimentos vegetais e têm se mostrado com boa aceitação por crianças de 7 meses de idade. 0 autor conclui que, em contraste às práticas realizadas em países desenvolvidos e em desenvolvimento, as carnes deveriam ser consideradas como um alimento a ser dado já no início da alimentação complementar para fornecer os micronutrientes essenciais.

Para identificar quais nutrientes ainda não estão sendo consumidos em quantidades suficientes, mesmo quando as necessidades energéticas são atingidas, é útil a comparação entre a densidade nutricional dos alimentos complementares e os níveis desejáveis.

Uma das limitações em se realizar esta análise é que só existe parâmetro de densidade desejável destes alimentos para crianças em aleitamento. Deve-se ter muito cuidado na interpretação destes resultados porque no grupo das crianças amamentadas foi retirado o leite materno da dieta, permanecendo os outros alimentos e bebidas.

Entre as crianças amamentadas no presente estudo, os nutrientes mais limitantes foram: tiamina, niacina, vitamina $\mathrm{B}_{6}$, ácido fólico, cálcio, ferro e zinco. Mais uma vez, o grupo etário entre 6 e 8 meses foi o que apresentou maiores inadequações nutricionais.

FABER e col (2004) observou que os alimentos complementares consumidos por crianças sul-africanas amamentadas, de 6 a 12 meses de idade, tinham as densidades de vitamina $A$, tiamina, riboflavina, niacina, vitamina $B_{6}$, vitamina $B_{12} e$ ácido fólico, cálcio, ferro e zinco abaixo do valor que é desejável. 
HOTZ e GIBSON (2001) encontraram que os alimentos complementares consumidos por crianças de 6 a 24 meses do Malawi tinham densidades inferiores às desejáveis de niacina, riboflavina, cálcio, ferro e zinco. PERLAS e col (2004) observaram que as densidades dos alimentos complementares, das crianças de $10 \mathrm{a}$ 22 meses das Filipinas, ficaram abaixo das desejáveis para todos os nutrientes estudados (vitamina A, tiamina, riboflavina, niacina e vitamina C), com exceção da proteína.

Na presente análise dos alimentos que mais contribuíram com o aporte de energia e nutrientes, pôde-se observar que os laticínios (leite de vaca) e o leite materno são os alimentos que estão mais presentes. A contribuição do leite materno só é marcante nos dois primeiros grupos etários, uma vez que as crianças de 12 a 24 meses já são desmamadas em sua maioria. Já os laticínios se fazem presentes em todos os grupos, confirmando seu alto consumo.

ZIEGLER e col (2006) também encontraram que os maiores fornecedores de energia da dieta de crianças americanas de 4 a 24 meses foram o leite materno e a fórmula infantil, que é mais consumida que o leite de vaca pelos lactentes americanos.

Outro achado interessante em nosso estudo é a contribuição dos espessantes como maiores fornecedores de ferro seguidos pelo feijão. FABER e col (2004), em seu estudo com crianças de 4 a 24 meses de uma comunidade da África do Sul, encontrou que, das crianças que consumiam espessantes infantis fortificados, $51 \%$ do ferro total ingerido foi fornecido por esses alimentos. Esses resultados revelam uma dieta pobre em qualidade e em variedade de alimentos, o baixo consumo de carnes e marcada pela monotonia alimentar. 
Em estudo com crianças americanas no primeiro ano de vida, DEE e col (2008) encontraram que aos 6 meses de idade 14\% consumia carne e aos 10,5 meses esta proporção aumentava para 85\%.

É importante ressaltar que, em nosso estudo, a mediana de consumo de proteína a partir de carnes das crianças de 6 a 11 meses foi igual a zero. Os maiores consumos de proteína de carnes e de ferro a partir de carnes se deram dos 12 aos 24 meses, quando atingiram valores medianos de 5,00 $\mathrm{g}$ e de 0,34 g, respectivamente. 0 menor consumo de ferro biodisponível foi entre as crianças de 6 a 8 meses, com valor mediano de $0,13 \mathrm{~g}$. A porcentagem mediana de ferro biodisponível variou de $8,13 \%$ a $8,88 \%$, o que mostra a maior das dietas com muito baixa ou baixa biodisponibilidade de ferro.

HOTZ e GIBSON (2001), descrevendo a dieta complementar de crianças menores de e 6 a 24 meses da área rural do Malawi, encontraram que a porcentagem de ferro biodisponível da dieta variou entre 5,5\% e 7,4\% nos grupos etários. RODRÍGUEZ e col (2007), em estudo com crianças mexicanas de 12 a 59 meses, encontraram que a ingestão média de ferro foi de $6,2 \mathrm{mg} /$ dia $(\mathrm{DP}=4.4) \mathrm{e}$ que a ingestão média de ferro biodisponível variou entre 0,14 e 0,37 mg/dia, representando $2,7-6,1 \%$ do ferro total ingerido. A concentração de hemoglobina esteve associada positivamente o ferro biodisponível nas crianças de 12 a 23 meses.

VITOLO e BORTOLINI (2007), em estudo com crianças de 12 a 16 meses de idade, encontraram entre as crianças não anêmicas maior proporção (16,3\%) de crianças com dietas com alta biodisponibilidade de ferro quando comparadas às anêmicas (10,5\%). Os autores concluíram que dietas com alta biodisponibilidade de ferro estão associadas à menor ocorrência de anemia na infância e podem ser 
utilizadas como medida de intervenção pela atenção básica de saúde e pelos departamentos de educação infantil. 


\section{CONSIDERAÇÕES FINAIS}

Discutir somente os aspectos nutricionais seria reduzir a dimensão da alimentação, como se bastasse intervir nas escolhas alimentares ou no conteúdo nutricional dos alimentos para que a população se tornasse plenamente saudável.

Não se pode apenas concluir que a população estudada realiza práticas inadequadas de alimentação complementar. Os problemas se estendem também à disponibilidade de alimentos saudáveis e seguros; à possibilidade de acesso aos mesmos, seja pela produção para consumo, seja por um trabalho que gere a renda necessária; à higiene dos alimentos no domicílio; à água limpa; ao saneamento adequado; às condições de vida e de habitação das famílias; ao nível de informação sobre higiene, práticas e hábitos alimentares saudáveis; às condições de saúde das pessoas e famílias; entre outros (VALENTE 2003).

Avaliar o consumo alimentar de crianças pequenas é, indiretamente, avaliar o consumo alimentar da família. Os maiores responsáveis pelas decisões do que comprar e do que oferecer para a criança são as mães ou os cuidadores. À medida que a idade da criança avança seus hábitos alimentares vão, cada vez mais, se aproximando aos hábitos adotados pelo restante da família.

No presente estudo, pôde-se observar que a renda familiar é baixa e que a população enfrenta problemas de acesso aos alimentos, sendo que a renda desempenha um fator limitante para a compra. Além disso, a região estudada não conta com um bom abastecimento de alimentos, prejudicando a disponibilidade e a qualidade dos alimentos e colaborando com a monotonia alimentar encontrada. 
A avaliação das práticas alimentares e do estado nutricional na infância é fundamental para orientar a elaboração e implementação de políticas e programas públicos capazes de promover o desenvolvimento humano sustentável, que tenha como um dos eixos centrais a redução das desigualdades sociais e econômicas (VALENTE 2003).

Na última PNDS (MS 2008) foram encontradas maiores prevalências de insegurança alimentar nos domicílios: localizados nas regiões Norte do país, com pessoa de referência com baixa escolaridade, com aglomeração domiciliar (sete ou mais moradores no domicílio), com crianças ou adolescentes na composição familiar, em que a entrevistada não estava trabalhando e não tinha trabalhado nos últimos 12 meses, entre outras condições. Nossa população concentra a maioria destas características, sendo de alto risco para apresentar insegurança alimentar.

SAHA e col (2008) estudaram a Segurança Alimentar e Nutricional dos domicílios de crianças menores de 12 meses de Bangladesh e sua relação com práticas alimentares. Os autores observaram que os níveis de Segurança Alimentar estiveram associados positivamente com melhores práticas alimentares. No entanto, não houve relação com o momento de introdução dos alimentos, mas sim com os tipos de alimentos oferecidos. Portanto, a renda familiar teve influência marcante na compra de mais variedades de alimentos, mas não no comportamento. Desta forma, a promoção de comportamentos mais adequados também é importante, complementando o efeito do aumento da renda familiar.

Em estudo de intervenção em uma comunidade da Índia, BHANDARI e col (2005) capacitaram profissionais da saúde para aconselhar as mães sobre aleitamento materno exclusivo ate o sexto mês e práticas apropriadas de alimentação complementar em múltiplos contatos, contando também com 
mobilização da comunidade e dos profissionais. Os momentos de intervenção com aconselhamento foram: o momento do nascimento, visitas domiciliares, sessões de vacinação e sessões de pesagem. O aumento do número de contatos para aconselhar as mães esteve associado positivamente com a prevalência de aleitamento materno exclusivo aos 3 meses, melhores práticas de alimentação complementar e aporte de energia. Comparadas às áreas de controle, as áreas de intervenção tiveram maior presença das crianças nas campanhas de vacinação, nas sessões de pesagem, nos centros de saúde públicos e maior cobertura de suplementação de vitamina A, ferro e ácido fólico. O estudo destacou a importância do aconselhamento realizado repetidas vezes, conseguido através do uso de múltiplos momentos, e concluiu que o direcionamento de recursos de um serviço que já existe para, adicionalmente, promover práticas alimentares mais adequadas não teve um efeito negativo no serviço, pelo contrário, otimizou a rotina de trabalho.

Os resultados do presente estudo sugerem intervenções para a promoção do aleitamento materno exclusivo até o sexto mês, com introdução de alimentos e práticas de alimentação complementar adequadas. É essencial melhorar a biodisponibilidade do ferro através do maior consumo de ferro total da dieta (carnes, feijão e caldos de carnes/feijão) e de vitamina C (incentivo ao consumo de frutas, legumes e hortaliças) desde o início da alimentação complementar, evitandose consumo de alimentos ricos em compostos inibidores da absorção do ferro, tais como café, chá, espessantes e leite de vaca. Com o aumento da idade da criança, o consumo de mingau deve ser gradualmente substituído, incentivando-se consumo de alimentos disponíveis para a família. 


\section{CONCLUSÃO}

No presente estudo, a anemia na infância mostrou-se um grave problema de saúde pública, com prevalência geral de $40 \%$. O déficit de estatura para idade também apresentou alta prevalência, de 12\%. A análise dos dados bioquímicos sugere deficiências das vitaminas $A$ e $B_{12}$ de importantes magnitudes, $15 \%$ e $12 \%$, respectivamente.

A prática do aleitamento materno exclusivo foi pouco prevalente e a introdução dos alimentos complementares foi realizada precocemente. Observou-se baixo consumo de frutas, hortaliças e carnes e excesso de consumo de leite de vaca e mingau, o que resultou em dieta pobre em ferro total, ferro biodisponível, ácido fólico, zinco, vitamina A e vitamina C. 


\section{REFERÊNCIAS BIBLIOGRÁFICAS}

1. Aggarwal A, Verma S, Faridi MMA, Dayachand. Complementary feeding reasons for inappropriateness in timing, quantity and consistency. Indian J Pediatr 2008;75:49-53.

2. Anderson VP, Cornwall J, Jack S, Gibson RS. Intakes from non-breastmilk foods for stunted toddlers living in poor urban villages of Phnom Penh, Cambodia, are inadequate. Matern Child Nutr 2008;4:146-59.

3. Assis AMO, Gaudenzi EN, Gomes G, Ribeiro RC, Szarfarc SC, Souza SB. Níveis de hemoglobina, aleitamento materno e regime alimentar no primeiro ano de vida. Rev Saúde Pública 2004;38:543-51.

4. Batista-Filho M, Rissin A. A transição nutricional no Brasil: tendências regionais e temporais. Cad Saúde Pública 2003;19:S181-S191.

5. Beard JL. Why iron deficiency is important in infant development. J Nutr. 2008,138:2534-6.

6. Benicio MHD e Monteiro CA. Desnutrição infantil nos municípios brasileiros: Risco de Ocorrência. São Paulo: NUPENS/USP; 1997.

7. Benicio MHD, Monteiro CA. Tendência secular da doença diarréica na infância na cidade de São Paulo (1984-1996). Rev Saúde Pública 2000;34:S83-S90.

8. Bhandari N, Mazumder S, Bahl R, Martines J, Black RE, Bhan MK. Use of multiple opportunities for improving feeding practices in under-twos within child health programmes. Health Policy Plan 2005;20:328-36.

9. Black RE, Allen LH, Bhutta ZA, Caulfield LE, de Onis M, Ezzati M, Mathers C, Rivera J; Maternal and Child Undernutrition Study Group. Maternal and child 
undernutrition: global and regional exposures and health consequences. Lancet. $2008 ; 371: 243-60$.

10. Bloem MW. Interdependence of vitamin A and iron: an important association for programmes of anaemia control. Proc Nutr Soc 1995;54:501-8.

11. Brekke HK, van Odijk J, Ludvigsson J. Predictors and dietary consequences of frequent intake of high-sugar, low-nutrient foods in 1-year-old children participating in the ABIS study. Br J Nutr 2007;97:176-81.

12. Brunken GS, Silva SM, França GV, Escuder MM, Venâncio SI. Risk factors for early interruption of exclusive breastfeeding and late introduction of complementary foods among infants in midwestern Brazil. J Pediatr 2006;82:445-51.

13. Bryce J, Boschi-Pinto C, Shibuya K, Black RE. WHO estimates of the causes of death in children. Lancet 2005;365:1147-52.

14. Carmel R. Cobalamina (Vitamina $B_{12}$ ). In: Shils ME, Olson JÁ, Shike M, Ross AC, editors. Tratado de Nutrição Moderna na Saúde e na Doença. Barueri: Manole; 2003.

15. Castro T, Baraldi L, Muniz P, Cardoso M. Dietary practices and nutritional status of 0-24-month-old children from Brazilian Amazonia. Public Health Nutr. 2009;4:1-8. [Epub ahead of print]

16. Chaparro CM. Setting the stage for child health and development: prevention of iron deficiency in early infancy. J Nutr. 2008;138:2529-33.

17. Colomer J, Colomer C, Gutierrez D, Jubert A, Nolasco A, Donat J, FernandezDelgado R, Donat F, Alvarez-Dardet C. Anaemia during pregnancy as a risk factor for infant iron deficiency: Report from the Valencia Infant Anaemia Cohort (VIAC) study. Paediatr Perinat Epidemiol. 1990;4:196-204. 
18. Coulthard H, Harris G, Emmett P. Delayed introduction of lumpy foods to children during the complementary feeding period affects child's food acceptance and feeding at 7 years of age. Matern Child Nutr 2009;5:75-85.

19. Cowin I, Emmett P; ALSPAC Study Team. Diet in a group of 18-month-old children in South West England, and comparison with the results of a national survey. J Hum Nutr Diet. 2007;20:254-67.

20. Dang S, Yan H, Yamamoto S, Wang X, Zeng L. Feeding practice among younger Tibetan children living at high altitudes. Eur J Clin Nutr 2005;59:1022-9.

21. DATASUS. Banco de dados do Sistema Único de Saúde [Acessado em 23/03/2009]. Disponível em: http://w3.datasus.gov.br/datasus/datasus.php

22. Dee DL, Sharma AJ, Cogswell ME, Grummer-Strawn LM, Fein SB, Scanlon KS. Sources of Supplemental iron among breastfed infants during the first year of life. Pediatrics 2008;122:S98-S104.

23. Dewey KG e Brown KH. Update on technical issues concerning complementary feeding of young children in developing countries and implications for intervention programs. Food and Nutrition Bulletin 2003;24:5-28.

24. Dewey KG, Cohen RJ, Rivera LL, Brown KH. Effects of age of introduction of complementary foods on iron status of breast-fed infants in Honduras. Am J Clin Nutr 1998;67:878-84.

25. Dewey KG. The challenges of promoting optimal infant growth. J Nutr $2001 ; 131: 1879-80$.

26. Domellöf M, Cohen RJ, Dewei KG, Hernell O, Rivera LL, Lonnerdal B. Iron supplementation of breast-fed Honduras and Swedish infants from 4 to 9 months of age. J Pediatr 2001;138:679-87. 
27. Domellöf M, Dewey KG, Lönnerdal B, Cohen RJ, Hernell O. The diagnostic criteria for iron deficiency in infants should be reevaluated. J Nutr $2002 ; 132: 3680-6$.

28. Drewett RF, Woolridge MW, Jackson DA, Imong SM, Mangklabruks A, Wongsawasdii L, Chiowanich P, Amatayakul K, Baum JD. Relationships between nursing patterns, supplementary food intake and breast-milk intake in a rural Thai population. Early Hum Dev 1989;20:13-23.

29. Faber M, Benadé AJS. Perceptions of infant cereals and dietary intakes of children aged 4-24 months in a rural South African Community. Int J Food Sciences Nutr 2001;52:359-365.

30. Fein SB, Labiner-Wolfe J, Scanlon KS, Grummer-Strawn LM. Selected complementary feeding practices and their association with maternal education. Pediatrics 2008;122:S91-S97.

31. Ferreira MU, Ferreira CS, Monteiro CA. Tendência secular das parasitoses intestinais na infância na cidade de São Paulo (1984-1996). Rev Saúde Pública 2000;34:S73-S82.

32. Figueiredo MG, Sartorelli DS, Zan TA, Garcia E, da Silva LC, de Carvalho FL, Pascotto RC, Macri S, Cardoso MA. Rapid assessment of current infant feeding practices in São José do Rio Preto, São Paulo, Brazil. Cad Saúde Pública $2004 ; 20: 172-9$

33. França GVA, Brunken GS, Silva SM Escuder SM, Venancio SI. Determinante da amamentação no primeiro ano de vida em Cuiabá, Mato Grosso. Rev Saúde Pública 2007;41:711-18.

34. García-Casal MN, Osório C, Landaeta M, Leets I, Matus P. Fazzino F, Marcos E. High prevalence of folic acid and vitamin $B_{12}$ deficiencies in infants, children, 
adolescents and pregnant women in Venezuela. Eur J Clin Nutr 2005;59:106470.

35. Gibson RS, Ferguson EL, Lehrfeld J. Complementary foods for infant feeding in developing countries: their nutrient adequacy and improvement. Eur J Clin Nutr. $1998 ; 52: 764-70$.

36. Gillespie S. Major issues in the control of iron deficiency. New York: The micronutrient initiative/ United Nations Children's Fund; 1998.

37. Global Health Council. Global health opportunities. 2006 update on priorities and U.S. investments. Washington, DC: Global Health Council, 2006:1-47.

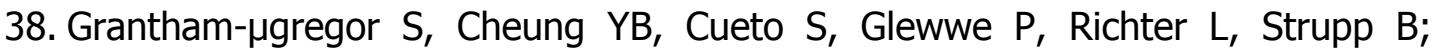
International Child Development Steering Group. Developmental potential in the first 5 years for children in developing countries. Lancet. 2007;369:60-70.

39. Hay G, Johnston C, Whitelaw A, Trygg K, Refsum H. Folate and cobalamin status in relation to breastfeeding and weaning in healthy infants. Am J Clin Nutr 2008;88:105-14.

40. Heaton TB, Forste R, Hoffmann JP, Flake D. Cross-national variation in family influences on child health. Soc Science Med 2005;60:97-108.

41. Hendricks K, Briefel R, Novak T, Ziegler P. Maternal and child characteristics associated with infant and toddler feeding practices. J Am Diet Assoc. 2006;106:S135-S148.

42. Hoffman W, Pons JA, Janer JL. The sedimentation concentration method in schistosomiasis mansoni. Puerto Rico J Public Health Trop Med 1934;9:283-91.

43. Hotz C, Gibson RS. Complementary feeding practices and dietary intakes from complementary foods amongst weanlings in rural Malawi. Eur J Clin Nutr. $2001 ; 55: 841-9$ 
44. Hurrell RF, Reddy MB, Juillerat MA, Cook JD. Degradation of phytic acid in cereal porridges improves iron absorption by human subjects. Am J Clin Nutr $2003 ; 77: 1213-9$.

45. IBGE. Contagem da população em 2007. Rio de Janeiro; 2007 [acesso em 18 fev. 2009]. Disponível em:

46. http://www.ibge.gov.br/home/estatistica/populacao/contagem2007/contagem.p df

47. IBGE. [homepage na internet]. Rio de Janeiro; 2009 [acesso em 23 mar 2009]. Disponível em:

48. http://www.ibge.gov.br/home/estatistica/populacao/censo2000/universo.php?tip $0=310 /$ tabela13_1.shtm\&uf $=12$

49. INACG - International Nutritional Anemia Consultative Group. INACG Symposium; 1999, Durban, South Africa. Washington DC: ILSI Research Foundation; 2000.

50. Institute of Medicine. National Research Council. Dietary reference intakes for vitamin A, vitamin K, arsenic, boron, chromium, copper, iodine, iron, manganese, molybdenum, nickel, silicon, vanadium and zinc. Washington DC: National Academic Press; 2000.

51. Jones G, Steketee RW, Black RE, Bhutta ZA, Morris SS. How many child deaths can we prevent this year? Lancet 2003;362:65-71.

52. Kalanda BF, Verhoeff FH, Brabin BJ. Breast and complementary feeding practices in relation to morbidity and growth in Malawian infants. Eur J Clin Nutr 2006;60:401-7.

53. Kramer MS, Kakuma R. The optimal duration of exclusive breast feeding. A systematic review. Adv Exp Biol 2004;554:63-77. 
54. Kramer K, Zimmermann MB. Nutricional Anemia. Sight and Life Press: Switzerland;2007.

55. Krebs NF, Hambidge KM. Complementary feeding: clinically relevant factors affecting timing and composition. Am J Clin Nutr 2007;85:639S-45S.

56. Kudlova E, Rames J. Food consumption and feeding patterns of Czech infants and toddlers living in Prague. Eur J Clin Nutr 2007;61:239-47.

57. Lind T, Lönnerdal B, Persson L, Stenlund H, Tennefors C, Hernell. Effects of weaning cereals with different phytate contents on hemoglobin, iron stores, and serum zinc: randomized intervention in infants from 6 to 12 mo of age. Am J Clin Nutr 2003;78:168-75.

58. Lira PIC, Lima MC, Silva GAP, Romani SAM, Eickmann SH, Alessio MLM, BatistaFilho M, Leger $\mathrm{CL}$, Huttly SR, Ashworth A. Saúde e Nutrição de crianças de áreas urbanas da Zona da Mata Meridional de Pernambuco: resultados preliminares de um estudo de coorte. Rev Bras Saúde Matern Infant 2003;3:463-472.

59. Lozoff B, Beard J, Connor J, Felt B, Georgieff M, Schallert T. Long-lasting neural and behavioral effects of iron deficiency in infancy. Nutr Rev 2006;64:34-43.

60. Lutter CK, Rivera JA. Nutritional status of infants and young children and characteristics of their diets. J Nutr. 2003;133:2941S-9S.

61. Lutter CK. Iron deficiency in young children in low-income countries and new approaches for its prevention. J Nutr. 2008;138:2523-8.

62. Mamabolo RL, Alberts M, Mbenyane GX, Steyn NP, Nthangeni NG, DelemarreVan De Waal HA, Levitt NS. Feeding practices and growth of infants from birth to 12 months in the central region of the Limpopo Province of South Africa. Nutrition 2004;20:327-33. 
63. MDS. Ministério do Desenvolvimento Social. Programa Bolsa Família: Lista de beneficiários. [acesso 2009 mai 15]. Disponível em:http://www.mds.gov.br/bolsafamilia/o_programa_bolsa_familia/lista-debeneficiarios

64. Michaelsen KF, Friis H. Complementary feeding: a Global Perspective. Nutrition $1998 ; 14: 763-6$

65. Monteiro CA, Benicio MHA, Konno SC, Silva ACF, Lima ALL, Conde WL. Causas do declínio da desnutrição infantil no Brasil, 1996-2007. Rev Saúde Pública $2009 ; 43: 35-43$.

66. Monteiro CA, Benicio MHD, Iunes R, Gouveia NC, Taddei JAAC, Cardoso MAA. ENDEF e PNSN: Para onde caminha o crescimento físico da criança brasileira? Cad Saúde Pública 1993;9:S85-S95.

67. Monteiro CA, Szarfarc SC, Mondini L. Tendência secular da anemia na infância na cidade de São Paulo (1984-1996). Rev Saúde Pública 2000;34:62-72.

68. Monteiro CA. A dimensão da pobreza, da desnutrição e da fome no Brasil. Estud Av 2003;17:7-20.

69. Mota DM, Barros AJD. Treinamento esfincteriano precoce: prevalência, características materna da criança e fatores associados numa coorte de nascimentos. Rev Bras Saúde Matern Infant 2008;8:103-11.

70. MS. Ministério da Saúde. Guia Alimentar para crianças menores de 2 anos. Brasília (DF); 2002.

71. MS. Ministério da Saúde. PNDS 2006 - Pesquisa Nacional de Demografia e Saúde da Criança e da Mulher. Brasília (DF); 2008.

72. MS. Ministério da Saúde. Informe da Atenção básica n 46. Ano IX, maio/junho. Brasília (DF); 2008b. 
73. MS. Ministério da Saúde. Agência Nacional de Vigilância Sanitária. 2008c [acesso 2008 out 06]. Disponível em: http://www.anvisa.gov.br/ALIMENTOS/farinha.htm

74. Nejar FF, Segall-Corrêa AM, Réa MF, Vianna RPT, Panigassi G. Padrões de aleitamento materno e adequação energética. Cad Saúde Pública 2004;20:6471.

75. Neuman NA, Tanaka OY, Szarfarc SC, Guimarães PRV, Victora CV. Prevalência e fatores de risco para anemia no Sul do Brasil. Rev Saúde Pública 2000;34:56-63.

76. Oliveira VC, Assis AMO, Pinheiro SMC, Barreto ML. Determinantes dos déficits ponderal e de crescimento linear de crianças menores de dois anos. Rev Saúde Pública 2006;40:874-82.

77. Osório MM, Lira PI, Ashworth A. Factors associated with $\mathrm{Hb}$ concentration in children aged 6-59 months in the state of Pernambuco, Brazil. $\mathrm{Br}$ J Nutr 2004;91:307-15.

78. Osório MM. Fatores determinantes da anemia em crianças. J Pediatr 2002;78:269-78.

79. PAHO/WHO. Guiding Principles for Complementary feeding of the breastfed Child. Washington DC: PAHO/WHO; 2004.

80. Pee S, Bloem MW, Sari M, Kiess L, Yip R, Kosen S. The high prevalence of low hemoglobin concentration among Indonesian infants aged 3-5 months is related to maternal anemia. J Nutr 2002;132:2215-21.

81. Perlas LA, Gibson RS, Adair LS. Micronutrient and selected vitamin intakes from complementary foods of infants and toddlers from Cebu, Philippines. Int J Food Sci Nutr 2004;55:1-15.

82. Rao R, Georgieff MK. Iron in fetal and neonatal nutrition. Semin Fetal Neonatal Med. 2007;12:54-63. 
83. Rao R, Tkac I, Townsend EL, Gruetter R, Georgieff MK. Perinatal iron deficiency alters the neurochemical profile of the developing rat hippocampus. J Nutr. $2003 ; 133: 3215-21$.

84. Rodríguez SC, Hotz C, Rivera JA. Bioavailable dietary iron is associated with hemoglobin concentration in Mexican preschool children. J Nutr. 2007;137:230410.

85. Saldiva SRDM, Escuder MM, Mondini L, Levy RB, Venancio SI. Feeding habits of children aged 6 to 12 months and associated maternal factors. J Pediatr 2007;83:53-8.

86. Silva LSM, Giugliani ERJ, Aerts DRGC. Prevalência e determinantes de anemia em crianças de Porto Alegre, RS, Brasil. Rev Saúde Pública 2001;35:66-73.

87. Simondon KB, Simondon F. Age at introduction of complementary food and physical growth from 2 to 9 months in rural Senegal. Eur J Clin Nutr $1997 ; 51: 703-7$.

88. Souza SB, Szarfarc SC, Souza JMP. Anemia no primeiro ano de vida em relação ao aleitamento materno. Rev Saúde Pública 1997;31:15-20.

89. Spinelli MG, Marchioni DM, Souza JM, Souza SB, Szarfarc SC. Risk factors for anemia among 6- to 12-month-old children in Brazil. Rev Panam Salud Pública $2005 ; 17: 84-91$.

90. Stoltzfus RJ. Research needed to strengthen science and programs for the control of iron deficiency and its consequences in young children. J Nutr $2008,138: 2542-6$.

91. Szarfarc SC, Berg G, Santos AL, Souza SB, Monteiro CA. Prevenção de anemia no primeiro ano de vida em centros de saúde do município de Santo André, São Paulo. J Pediatr 1996;72:329-34. 
92. Szarfarc SC, Souza SB, Furumoto RAV, Brunken GS, Assis AMO, Gaudenzi EM, et al. Concentração de hemoglobinas em crianças do nascimento até um ano de vida. Cad Saúde Pública 2004;20:266-74.

93. Taneja S, Bhandari N, Strand TA, Sommerfelt $H$, Refsum $H$, Ueland PM, Schneede J, Bahl R, Bhan MK. Cobalamin and folate status in infants and young children in a low-to-middle income community in India. Am J Clin Nutr 2007;86:1302-9.

94. Tympa-Psirropoulou E, Vagenas C, Psirropoulos D, Dafni O, Matala A, Skopouli F. Nutritional risk factors for iron-deficiency anaemia in children 12-24 months old in the area of Thessalia in Greece. Int J Food Sci Nutr 2005;56:1-12.

95. UNICEF/IBGE. Fundo das Nações Unidas para a Infância/Instituto Brasileiro de Geografia e Estatística. Municípios brasileiros: crianças e suas condições de sobrevivência - censo demográfico, 1991. Brasília: UNICEF/ IBGE; 1994.

96. UNICEF - Fundo das Nações Unidas para a Infância. Situação da infância brasileira 2006. [acesso 2009 mar 24]. Disponível em: http://www.unicef.org/brazil/pt/Pags_108_123_IDI_Abre.pdf

97. UNICEF - Fundo das Nações Unidas para a Infância. Situação Mundial da Infância 2008: Sobrevivência Infantil. Brasília: UNICEF; 2007.

98. US Department of Agriculture. Food and Nutrient Database for Dietary Studies, 3.0. 2008. Beltsville, MD: Agricultural Research Service, Food Surveys Research Group.

99. Valente FLS. Fome, desnutrição e cidadania: inclusão social e direitos humanos. Saúde Soc 2003;12:51-60. 
100. Victora CG, Adair L, Fall C, Hallal PC, Martorell R, Richter L, et al. Maternal and child undernutrition: consequences for adult health and human capital. Lancet 2008;371:340-57.

101. Vieira GO, Silva LR, Vieira Tde O, Almeida JA, Cabral VA. Feeding habits of breastfed and non-breastfed children up to 1 year old. J Pediatr 2004;80:411-6.

102. Vieira MLF, Pinto e Silva JLC, Barros Filho AA. A amamentação e a alimentação complementar de mães adolescentes são diferentes das de filhos de mães adultas? J Pediatr 2003;79:317-24.

103. Villamor E, Mora-Plazas M, Forero Y, Lopez-Arana S, Baylin A. Vitamin $B_{12}$ status is associated with socioeconomic level and adherence to an animal food dietary pattern in Colombian school children. J Nutr 2008;138:1391-8.

104. Vitolo MR, Bortolini GA. Iron bioavailability as a protective factor against anemia among children aged 12 to 16 months. J Pediatr 2007;83:33-8.

105. Vuilleumier JP, Keller HE, Gysel D, Hunziker F. Clinical chemical methods for the routine assessment of the vitamins status in human populations. Int J Vitam Nutr Res 1983;53:265-272.

106. Ward KL, Tkac I, Jing Y, Felt B, Beard J, Connor J, Schallert T, Georgieff MK, Rao R. Gestational and lactational iron deficiency alters the developing striatal metabolome and associated behaviors in young rats. J Nutr 2007;137:1043-9.

107. Wayland C. Breasfeeding patterns in Rio Branco, Acre, Brazil: a survey of reasons for weaning. Cad Saúde Pública 2004;20:1757-1761.

108. Wharf SG, Fox TE, Fairweather-Tait SJ, Cook JD. Factors affecting iron stores in infants 4-18 months of age. Eur J Clin Nutr 1997;51:504-9. 
109. WHO. Preventing and controlling iron deficiency anaemia through primary health care: a guide for health administrators and programme managers. Geneva; 1989.

110. WHO. Indicators for assessing breastfeeding practices. Geneva; 1991.

111. WHO. Physical status: the use and interpretation of anthropometry. Geneva; 1995.

112. WHO. Indicators for assessing vitamin A deficiency and their application in monitoring and evaluating intervention programmes. Geneva; 1996.

113. WHO. Complementary feeding of young children in developing countries: a review of a current scientific knowledge. Geneva; 1998.

114. WHO. Iron deficiency anaemia: assessment, prevention and control - a guide for programs managers. Geneva; 2001.

115. WHO. World Health Assembly Resolution. Infant and young child nutrition. Geneva; 2001b.

116. WHO. Vitamin and mineral requirements in human nutrition. Geneva: World Health Organization, 2002.

117. WHO/UNICEF. Global Strategy for infant and young child feeding. Geneva; 2003.

118. WHO. Vitamin and Mineral requirements in human nutrition. Second edition. Geneva; 2004.

119. WHO. WHO Child Growth Standards. Methods and development: Length/height-for-age, weight-for-age, weight-for-length, weight-for-height and body mass index-for-age. Geneva; 2006.

120. WHO. Assessing the iron status of populations. $2^{\text {nd }}$ edition. Geneva;2007. 
121. WHO Anthro for PC, version 2. Geneva: WHO; 2007b [acesso em 14 jan 2009]. Disponível em: http://www.who.int/childgrowth/software/en

122. WHO. World Health Statistics 2008. Geneva; 2008.

123. WHO. Worldwide prevalence of anaemia 1993-2005: WHO Global Database on Anaemia. Geneva; 2008b.

124. WHO. Indicators for assessing infant and young child feeding practices: conclusions of a consensus meeting held 6-8 November 2007 in Washington D.C., USA. Geneva; 2008c.

WHO. Making pregnancy safer: a newsletter of worldwide activity. Geneva; 2009. [acesso em 18 mai 2009]. Disponível em: http://www.who.int/making_pregnancy_safer/documents/newsletter/mps_newsl etter_issue6.pdf

125. WHO. Global prevalence of vitamin A deficiency in populations at risk 19952005. WHO Global Database on Vitamin A Deficiency. Geneva; 2009b.

126. Ziegler P, Hanson C, Ponza M, Novak T, Hendricks K. Feeding Infants and Toddlers Study: meal and snack intakes of Hipanic and Non-Hispanic infants and toddlers. J Am Diet Assoc 2006;106:S107-S123.

127. Ziegler $P$, Briefel $R$, Ponza $M$, Novak $T$, Hendricks $K$. Nutrient intakes and food patterns of toddler's lunches and snacks: influence of location. J Am Diet Assoc 2006b;106:S124-S134. 


\section{ANEXOS}

ANEXO 1: Questionário Sociodemográfico Domiciliar

Condiçōes de Saúde e Nutriçāo de Crianças da Amazônia Ocidental Brasileira QUESTINONÁRIO 1
SÓCIO ECONÔMICO-FAMILIAR / MÄE OU RESPONSÁVEL PELAS CRIANCCAS

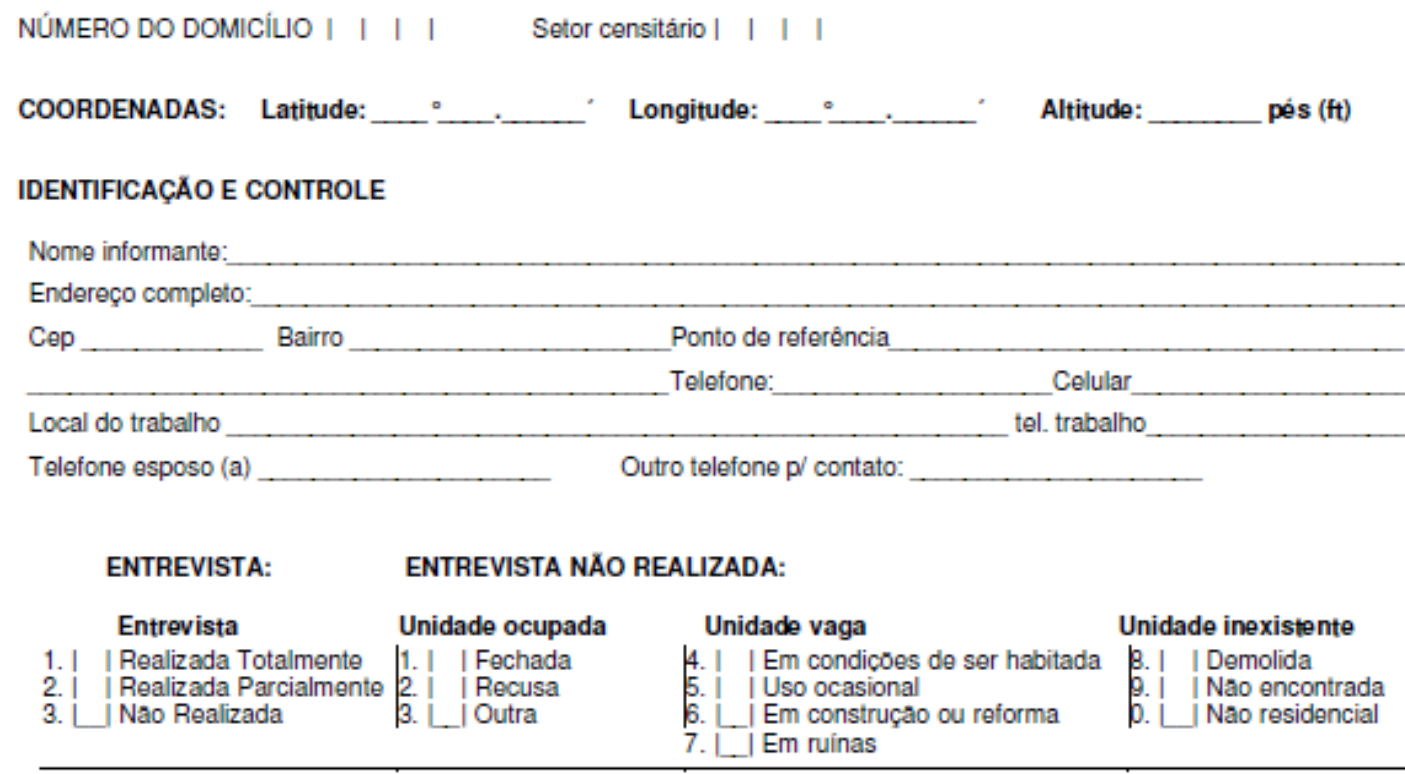

MORADORES

Menores de dez anos

15 anos ou mais $\downarrow \mid$

VISITA EFETUADA EM:

Data da entrevista

Fntravistarinr:

L_I_I_I_IL_L_ا Total de visitas 
Nesta primeira parte da entrevista farei perguntas sobre as pessoas que moram nesta casa que chamarei na maioria das vezes de domicilio. Depois, farei perguntas sobre as caracteristicas deste domicilio. Todas as informaçōes fornecidas serão estritamente confidenciais.

QUAL É O NOME DA PESSOA CONSIDERADA A PRINCIPAL RESPONSÁVEL POR ESTE DOMICILIO? Responsável:

\section{Relação de moradores}

\section{CONDIÇÃO DO MORADOR NA UNIDADE NA FAMILIA}

\begin{tabular}{|c|c|c|c|c|}
\hline Nome & $\begin{array}{l}\text { 1- Chefe da familia } \\
2 \text { - Esposo(a) } \\
3 \text { - Filho(a) } \\
4 \text { - Outro parente } \\
5 \text { - Agregado } \\
6 \text { - Empregado(a) } \\
7 \text { - Outros }\end{array}$ & $\begin{array}{l}\text { Sexo } \\
1 \text { - masc } \\
2 \text { - femin }\end{array}$ & $\begin{array}{l}\text { Idade } \\
\text { em anos e } \\
<1 \text { ano }\end{array}$ & $\begin{array}{l}\text { Data Nascimento } \\
\text { DD/ MM / AAAA }\end{array}$ \\
\hline & Chefe da familia & & & 1 \\
\hline & & & & 1 \\
\hline & & & & 1 \\
\hline & & & & 1 \\
\hline & & & & 1 \\
\hline & & & & 1 \\
\hline & & & & 1 \\
\hline & & & & 1 \\
\hline & & & & 1 \\
\hline & & & & 1 \\
\hline & & & & 1 \\
\hline & & & & 1 \\
\hline & & & & 1 \\
\hline & & & & 7 \\
\hline & & & & 1 \\
\hline & & & & 1 \\
\hline & & & & 1 \\
\hline & & & & 1 \\
\hline & & & & 1 \\
\hline & & & & 1 \\
\hline & & & & 11 \\
\hline
\end{tabular}

Eu listei (leia os nomes relacionados no quesito 1) ( ) sim ( ) nao

Há alquém morando aqui, inclusive alquma criança recém-nascida $($ ) sim $($ ) nao

Eu omiti alguma pessoa que normalmente vive aqui, mas está temporariamente ausente por motivo de trabalho, internaçao em hospital ou outra razao? ( ) sim ( ) nao

\section{CARACTERISTICAS DA UNIDADE DOMICILIAR}

As perguntas que irei fazer agora são sobre este domicilio onde o(a) Sr.(a) mora.

\section{TIPO DO DOMICÍLIO:}

1 L. I Casa

4 L. Barraco
2 L. | Apartamento

5 L. I Outro

3 L | Cômodo (especifique)
2. tipodo

3 TIPO DE PAREDE:

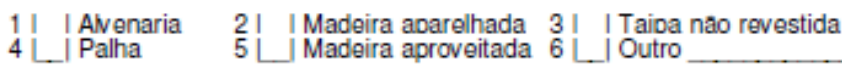
(especifique)

\section{TIPO DE PISO:}

1 | | Terra batida 2 | | Cimento/Tiiolo 4 L. I Palha 3 | | Taipa nao revestida 6 | | Outro
3. parede

4. piso 


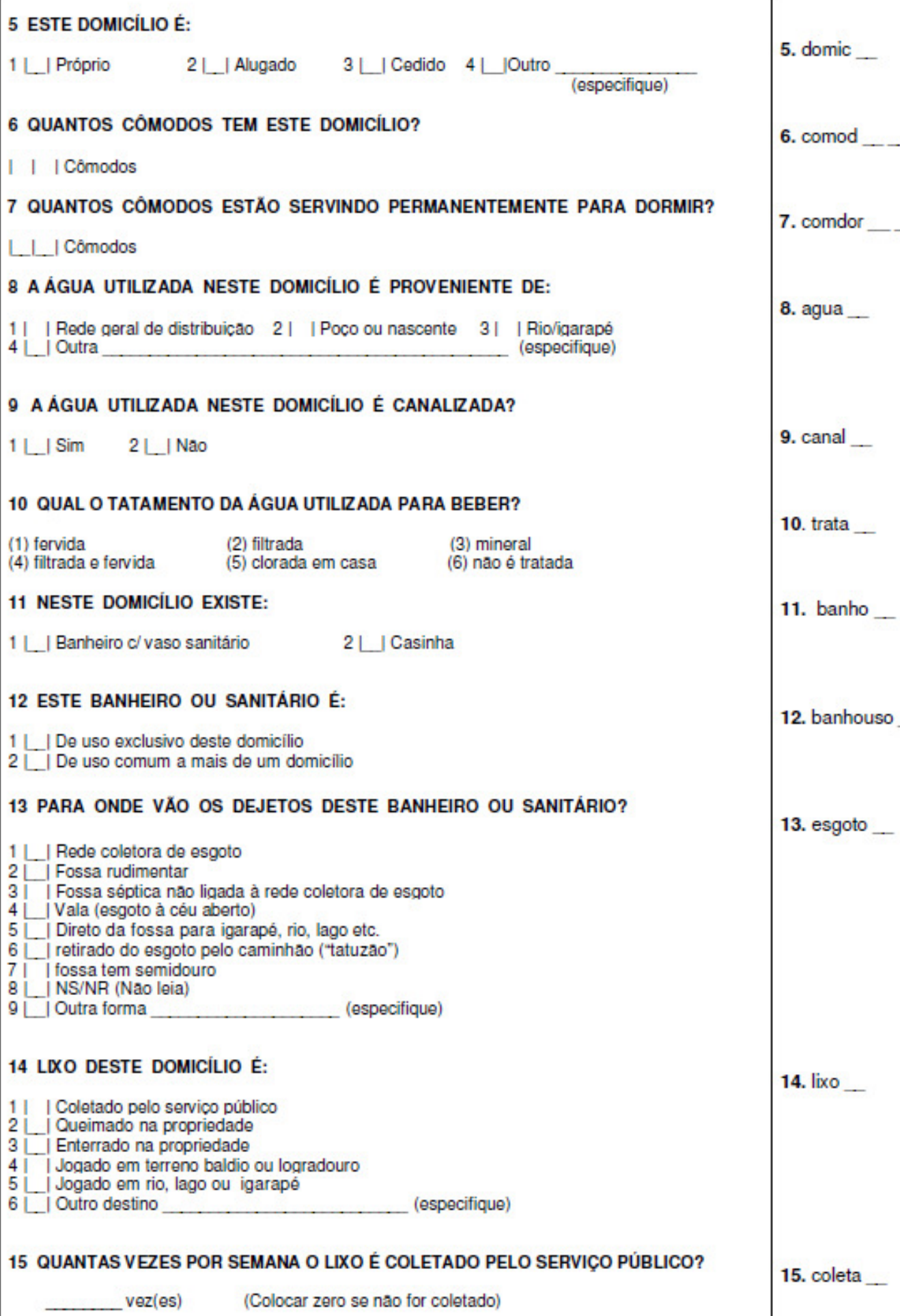

15 QUANTAS VEZES POR SEMANA O LIXO É COLETADO PELO SERVIÇO PÚBLICO?

5. domic

6. comod

7. comdor

8. agua

9. canal

10. trata

11. banho

12. banhouso

13. esgoto

14. lixo

15. coleta 


\begin{tabular}{|c|c|c|c|}
\hline \multicolumn{3}{|c|}{16 ESTE DOMICILIO TEM ENERGIA ELETRICA? } & \multirow{3}{*}{ 16. ener __ } \\
\hline 1| | Sim & \multicolumn{2}{|c|}{2 | | Nao } & \\
\hline \multicolumn{3}{|c|}{17 ESTE DOMICILIO UTILIZA FOGÃO A LENHA/CARVÃO? } & \\
\hline $\begin{array}{l}1 \text { L. I Nao } \\
3 \text { | I Sim, usa fogao a lenha } \\
5 \text { L. Sim, usa fogaa a lenha e carv }\end{array}$ & \multicolumn{2}{|c|}{$\begin{array}{l}2 \text { L L I Sim, mas usa raramente ( }<\text { 1vez/semana) } \\
4 \text { L_ Sim, usa somente fogáo a carvao }\end{array}$} & 17. fogao _ \\
\hline \multicolumn{3}{|c|}{18 SE UTILIZA FOGĂO A LENHA/CARVÃO, ONDE FICA O FOGÃO: } & 18. fogcasa \\
\hline $\begin{array}{l}1 \text { L I Dentro da casa } \\
\text { 3.| | Nao tem/nao usa fogao a lenha }\end{array}$ & \multicolumn{2}{|c|}{2 L_ | Fora da casa } & \\
\hline \multicolumn{4}{|c|}{19 QUAIS DOS BENS ABAIXO EXISTEM EM SEU DOMICILIO? } \\
\hline a) televisao & (1) Sim & (2) Nao & \multirow{5}{*}{$\begin{array}{l}\text { 19a. tv __ } \\
\text { 19b. apas _ } \\
\text { 19c. videoc _ } \\
\text { 19d. fogão __ }\end{array}$} \\
\hline b) aparelho de som & (1) Sim & (2) Nao & \\
\hline c) video cassete/aparelho de dvd & (1) Sim & (2) Nao & \\
\hline d) fogáo a gás & (1) Sim & (2) Nao & \\
\hline ө) geladeira & (1) Sim & (2) Nao & \\
\hline f) rádio & (1) Sim & (2) Nao & 19e. gela __ \\
\hline g) telefone fixo/celular & (1) Sim & (2) Nao & 19f. radio _- \\
\hline h) liquidificador & (1) Sim & (2) Nao & 19g. telefo _. \\
\hline i) bicicleta & (1) Sim & (2) Nao & 19h. liqui _. \\
\hline j) ferro elétrico & (1) Sim & (2) Nao & 19i bicid __ \\
\hline k) carro & (1) Sim & (2) Nao & 19j. ferro \\
\hline l) jogo de sala estofado & (1) Sim & (2) Nao & 19k. car - \\
\hline m) máquina/tanque de lavar roupa & (1) Sim & (2) Nao & 19k. Call - \\
\hline n) antena parabólica & (1) Sim & (2) Nao & 19l. joges__ \\
\hline o) moto & (1) Sim & (2) Nao & 19m. mala v__ \\
\hline p) microondas & (1) Sim & (2) Nao & 19n. antpar _- \\
\hline q) proprietário de colônia/terra & (1) Sim & (2) Nao & 190. moto _. \\
\hline r) proprietário de gado & (1) Sim & (2) Nao & 19p. micr__ \\
\hline \multicolumn{3}{|c|}{$\begin{array}{l}20 \text { O (A) CHEFE OU O RESPONSÁVEL PELA FAMILIA R (A) FREQÖENTOU A ESCOLA? } \\
\text { Se sim, até que série completou? série grau } \\
\text { (00) nao frequentou escola e não sabe ler/escrever } \\
\text { (88) nao frequentou escola, mas sabe ler e escrever } \\
\text { (99) nao sabe/ nao informa }\end{array}$} & 20. escola __ \\
\hline \multicolumn{3}{|l|}{$\begin{array}{l}21 \text { HÁ FUMANTES NO DOMICILIO? } \\
1 \text { | | Sim }\end{array}$} & 21. fumo __ \\
\hline \multicolumn{3}{|c|}{$\begin{array}{l}22 \text { SE HÁ FUMANTES NO DOMICILIO, QUANTAS PESSOAS FUMAM E QUEM? } \\
\text { pesSOaS }\end{array}$} & 22a.fumpes__ \\
\hline \multicolumn{3}{|l|}{\begin{tabular}{l|l|l}
1 & | Pai \\
2 & L & Mae \\
3 & L_l Irmaos \\
4 & L | Avós \\
5 & | Tios \\
5 & L. $\mid$ Outros
\end{tabular}} & 22b. fumfam _ \\
\hline
\end{tabular}




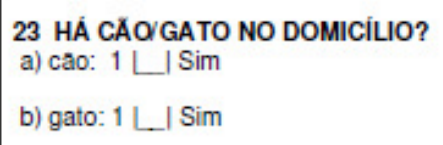

As questōes a seguir deverão ser respondidas pela mãe ou responsável pela criança

24 IDADE MÃE/RESPONSẢVEL :

_... anos

data nascimento:

25 HÁ QUANTO TEMPO A SENHORA MORA NESTA CIDADE?

1 L. I menos de 1 ano $\quad 4 \mathrm{~L}$ desde que nasceu

2 L. I de 1 a 5 anos $\quad 9\llcorner$ nao sabe/nao lembra

3 L. I mais de 5 anos $\quad 8$ L. I nao se aplica

26 A SENHORA ESTUDOU NA ESCOLA?

Se sim, até que série completou? ___série___ grau

$(00)$ nao frequentou escola $e$ nao sabe leriescrever

(88) nao frequentou escola mas sabe ler e escrever

(99) nao sabe/ nao informa

27 A SENHORA ESTÁ CASADA OU MORA COM UM COMPANHEIRO?

$$
1 \text { L I Sim 2 L_ | NaO }
$$

28 SE TEM COMPANHEIRO, HÁ QUANTO TEMPO ESTÃO CASADOS OU MORAM JUNTOS? _ _ anos 0 L_l menos de 1 ano 99 LI nao sabe/nao informa

29 SE JÁ FICOU GRÁVIDA, QUANTAS VEZES AO TODO?

$$
88 \text { L. I nunca engravidou }
$$

29. vezgra

30 IDADE NA PRIMEIRA GRAVIDEZ? ___ anos

31 QUANTOS FILHOS NASCERAM VIVOS?

_._. filhos

32 DOS FILHOS QUE NASCERAM VIVOS, ALGUM FILHO MORREU ANTES DOS 5 ANOS? filhos

(00) nenhum filho morreu (88)nunca engravidou (99) nao sabe/ nao lembra

33 QUAL ERA A IDADE DA SENHORA NA ÚLTIMA GRAVIDEZ? anos

(considerar idade atual se estiver grávida) $88 \mathrm{~L}$ | nunca engravidou $99 \mathrm{~L}$. I nao lembra

34 QUAL É A SUA OCUPAÇÃo ?

1 L. I dona de casa

2| | doméstica, faxineira, serviços gerais

3 L. l comércio

$4 \mathrm{~L}$ | agricultura

5 L serviços técnicos (escola, secretaria, etc)

6 | | assistencial (igrejas) I outros:
24. idadm

25.Tempm

26. escolmae

27. econj _.

28. teconj

30. idprgra

31. quavi

32.quamac

33. idault

34. ocuma 
ANEXO 2: Questionário de Condições de Saúde da Criança

Condiçōes de Saúde e Nutrição de Crianças da Amazônia Ocidental Brasileira

\section{CARACTERISTICAS DA CRIANÇA}

Número domicilio:

Número da criança:

Nome da criança:

Nome informante:

Endereço completo

Ponto de referência:

Telefone(s):

Entrevistador: inicio (s) : / término:

\begin{tabular}{|c|c|}
\hline Data: _. I _ / $2007\left(1^{3}\right)$ & resultado da entrevista: \\
\hline lata: _. I__ / 2007 (2 visita) & resultado da \\
\hline ata: _. I_ / 2007 ( $3^{a}$ visita) & \\
\hline
\end{tabular}

Códigos

01 - entrevista completa

02 - entrevista incompleta

03 - moradores ausentes

04 - adiada

05 - recusa total

06 - domicilio desocupado

77 - outra

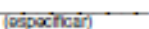

Revisado pelo entrevistador?

Ėinatura do orriowitador

Revisado pelo supervisor?

Esinfura do sipénisot

\section{Confidencial}

As Informaçces sollcltadas neste questionárı săo confldenclals e só serâo utlllzadas para fins estatísticos. Este questlonárlo deverá ser respondido pela mâ da crlança mener de 10 anos selecionada para o estudo. Caso esta nâo tenha mae ou nào more com ela, a responsável, substituta da mâe da crlança é quem deverá responder as questoes. 


\begin{tabular}{|c|c|}
\hline 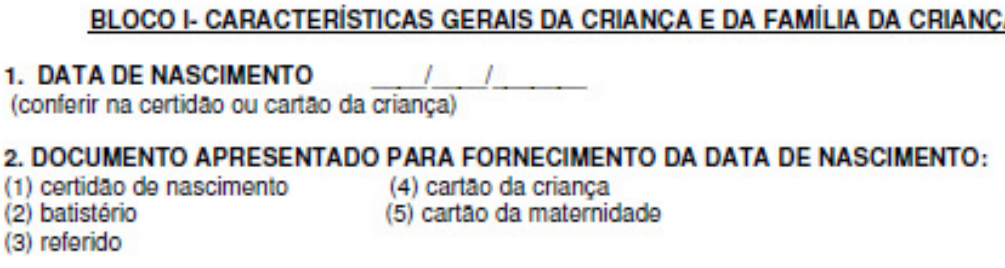 & 1. Idade _ I I \\
\hline 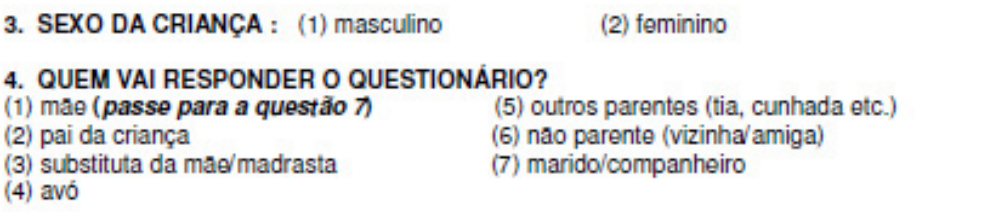 & 3. sexocri _- \\
\hline $\begin{array}{l}\text { 5. HÁ QUANTO TEMPO A SENHORA CUIDA DE (NOME DA CRIANÇA)? } \\
\begin{array}{ll}\text { (1) desde que nasceu } & \text { (5) há menos de } 1 \text { ano } \\
\text { (2) há mais de } 4 \text { anos } & \text { (8) nåo se aplica (mâe da criança) } \\
\text { (3) de } 3 \text { a } 4 \text { anos } & \text { (9) nào sabelnao lembra } \\
\text { (4) de } 1 \text { a } 2 \text { anos } & \end{array}\end{array}$ & 5. temsub _... \\
\hline $\begin{array}{l}\text { 6. POR QUE A MAEE NĂO MORA COM (NOME DA CRIANÇA)? } \\
\begin{array}{ll}\text { (1) por motivo de trabalho } & \text { (5) por problemas financeiros } \\
\text { (2) constituiu outra familia } & \text { (7) outro: } \\
\text { (3) motivo de doença } & \text { (8) nâ se aplica (mae da criança) } \\
\text { (4) nao quis assumir o filho } & \text { (9) nâo sabe/ nao lembra }\end{array}\end{array}$ & 6. motma1 \\
\hline $\begin{array}{l}\text { 7. O PAI DE (NOME DA CRIANÇA) MORA COM ELA (E)? } \\
\text { (1) sim } \\
\text { (2) nao, faleceu (passe para questao 11) } \\
\text { (3) nâo, outros motivos } \\
\text { (9) nao sabe/nao informa }\end{array}$ & 7. morpai \\
\hline $\begin{array}{l}\text { 8. O PAI DA CRIANCA ESTUDOU NA ESCOLA? } \\
\text { Se sim, até que série completou? série_grau } \\
(00) \text { nao frequentou escola e nåo sabe leriescrever } \\
(88) \text { nao frequentou escola mas sabe ler e escrever } \\
\text { (99) nao sabel nao informa }\end{array}$ & 8. escolpai \\
\hline $\begin{array}{l}\text { 9. O PAI DA CRIANÇA ESTÁ TRABALHANDO? } \\
\begin{array}{ll}\text { (1) sim, só um periodo (manha ou tarde) } & \text { (3) sim, sem periodo definido } \\
\text { (2) sim, em dois periodos (manha } \theta \text { tarde) } & \text { (4) nao trabalha }\end{array}\end{array}$ & 9. trabpai: __ \\
\hline $\begin{array}{l}\text { 10. QUAL É A OCUPAÇÃO DO PAI DA CRIANÇA? } \\
\text { (1) faxineiro, serviços gerais } \\
\text { (2) comércio } \\
\text { (3) agricultura } \\
\text { (4) serviços técnicos (escola, secretaria, etc.) } \\
\text { (5) assistencial (igrejas) } \\
\text { (6) seringueiro/extrativista } \\
\text { (7) outros: }\end{array}$ & 10. ocupai __ \\
\hline 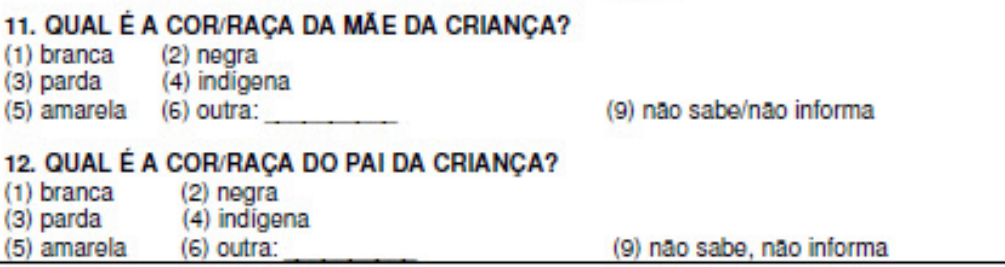 & 11. cormae _. \\
\hline
\end{tabular}




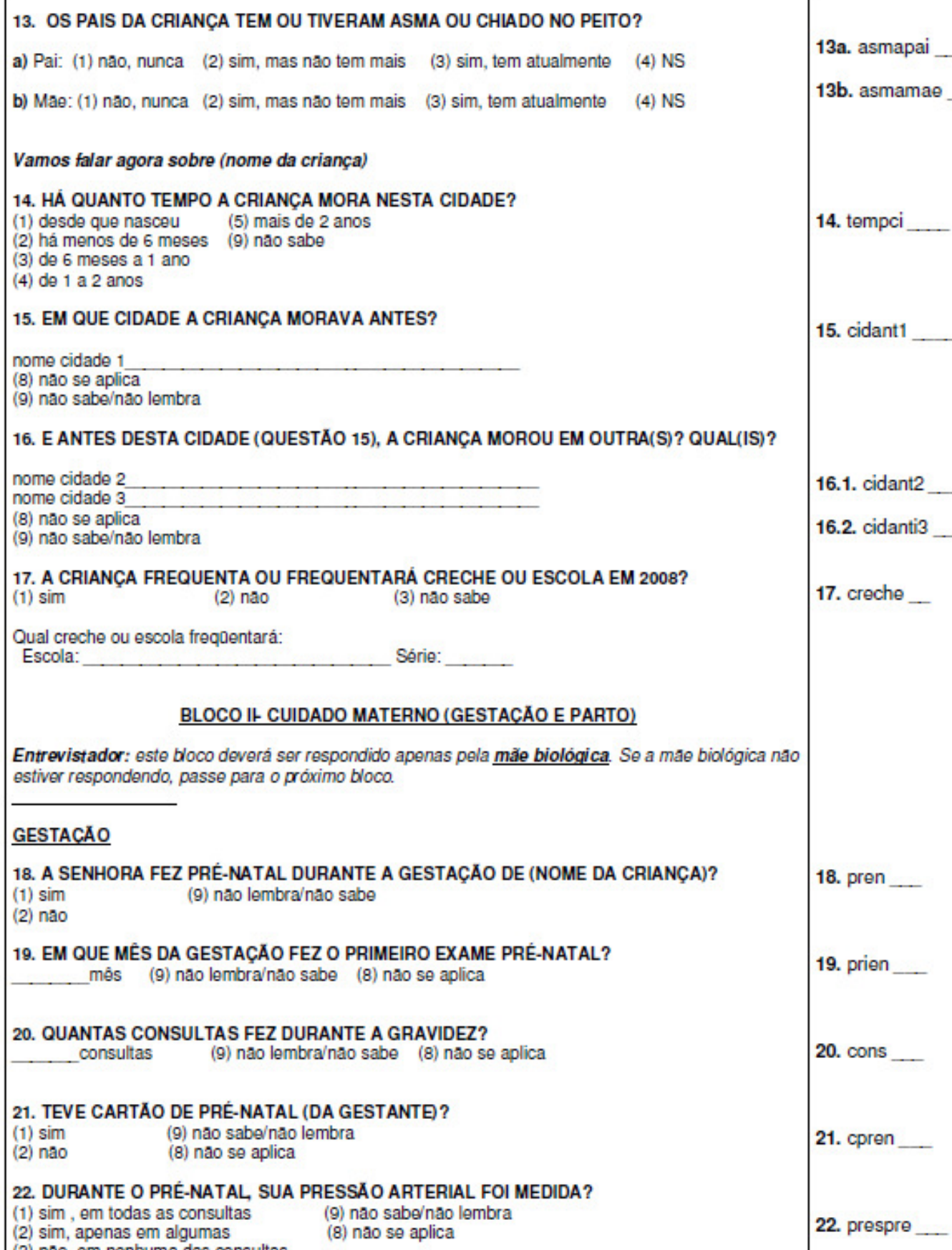

Entrevistador: este bloco deverá ser respondido apenas pela mäe biológica. Se a mae biológica nao estiver respondendo, passe para o próximo bloco.

\section{GESTACAO}

18. A SENHORA FEZ PRÉ-NATAL DURANTE A GESTAÇĂO DE (NOME DA CRIANÇA)?

$\begin{array}{ll}\text { (1) } \operatorname{sim} & \text { (9) nao lembra/nao sabe }\end{array}$

(2) nao

19. EM QUE MÊS DA GESTAÇĀO FEZ O PRIMEIRO EXAME PRÉ-NATAL? més (9) nâo lembra/náo sabe (8) nâo se aplica

20. QUANTAS CONSULTAS FEZ DURANTE A GRAVIDEZ?

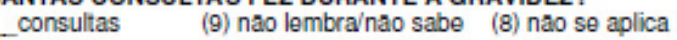

16.1. cidant2

16.2. cidanti3

17. creche

14. tempci

15. cidant 1

18. pren

19. prien

21. TEVE CARTÃO DE PRÉ-NATAL (DA GESTANTE)?

$\begin{array}{ll}\text { (1) } \mathrm{sim} & \text { (9) nao sabe/nao lembra } \\ \text { (2) nao } & \text { (8) nao se aplica }\end{array}$

22. DURANTE O PRÉ-NATAL, SUA PRESSÃO ARTERIAL FOI MEDIDA?

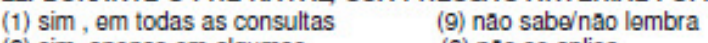

$\begin{array}{ll}\text { (2) sim, apenas em algumas } & \text { (8) nao se aplica }\end{array}$ 
23. DURANTE O PRÉ-NATAL SEU PESO FOI MEDIDO?
(1) $\mathrm{sim}$, em todas as consultas
(9) nao sabe/nao lembra
(2) sim, apenas em algumas
(8) naa se aplica
(3) nao, em nenhuma das consultas

23. pespre

24. DURANTE A GESTAÇĀO RECEBEU ORIENTAÇÃO SOBRE ALEITAMENTO MATERNO ?

(1) $\operatorname{sim} \quad$ (9) nao lembra/ nao sabe

(2) nao

25. DURANTE A GESTAÇÃO RECEBEU ORIENTAÇÃO SOBRE COMO EVITAR FILHOS APÓS O PARTO?

(1) $\operatorname{sim} \quad$ (9) nao lembra/ nao sabe

(2) nao

26. DURANTE ESTA GRAVIDEZ, A SENHORA APRESENTOU ALGUM DOS SEGUINTES PROBLEMAS DE SAÚDE?

$\begin{array}{llll}\text { a) hemorragia } & \text { (1) } \operatorname{sim} & \text { (2) nao } & \text { (9) nao sabe/nao lembra } \\ \text { b) inchaço nas pernas } & \text { (1) } \operatorname{sim} & \text { (2) nao } & \text { (9) nao sabe/nao lembra } \\ \text { c) pressao alta } & \text { (1) } \operatorname{sim} & \text { (2) nao } & \text { (9) nao sabe/nao lembra } \\ \text { d) anemia } & \text { (1) } \operatorname{sim} & \text { (2) nao } & \text { (9) nao sabe/nao lembra } \\ \text { e) diabetes } & \text { (1) } \operatorname{sim} & \text { (2) nao } & \text { (9) nao sabe/nao lembra } \\ \text { f) intemaçao por qualquer motivo } & \text { (1) } \operatorname{sim} & \text { (2) nao } & \text { (9) nao sabe/nao lembra } \\ \text { g) malária } & \text { (1) } \operatorname{sim} & \text { (2) nao } & \text { (9) nao sabe/nao lembra }\end{array}$

27. A SENHORA FUMOU DURANTE A GESTACĀO ?

(1) sim, sempre

(2) sim, algumas vezes

(3) nao, mas fumava antes da gravidez

(4) năo fuma/nunca fumou

(9) nao lembra/ nao sabe

28. A SENHORA TOMOU BEBIDA ALCOÓLICA DURANTE A GESTAÇÃO?

(1) sim, sempre

(2) sim, algumas vezes

(3) nao, mas bebia antes da gravidez

(4) nao bebe/nunca bebeu

(9) nao lembra/ nao sabe

Vamos agora falar sobre o parto de (nome da criança)

29. ONDE (NOME DA CRIANCCA) NASCEU ?

(1) em hospital ou maternidade público

(2) em hospital ou maternidade particular ou corvênio

(3) em casa

(7) outro:

(9) nao sabe / náo lembra

30. COMO FOI O PARTO DE (NOME DA CRIANCA) ?
(1) natural
(3) fórceps (tirado a ferro)
30. Parto

(2) cesária

(9) não sabe/nao lembra

31. (NOME DA CRIANCA) É GÊMEO ?

$\begin{array}{lll}\text { (1) } \operatorname{sim} & \text { (2) nao }\end{array}$

31. gêmeo

32. QUEM FEZ O PARTO DE (NOME DA CRIANCA) ?
(1) médico
(5) pariu sozinha
(2) enfermeira
(6) outra pessoa (nao profissional ou parteira)
(3) auxiliar de enfermagem
(9) nao sabe / nao lembra

29. onden

(4) parteira

26.a. sang

26.b. inch

26.c. pres

26.d. anem

26.e. açuc

26.f. intges

26.g. malges

27. fumog

28. alcog 
33. DURANTE O PARTO OU LOGO DEPOIS (ATÉ 45 DIAS) A SENHORA APRESENTOU ALGUM PROBLEMA:
a) hemorragia
(1) $\operatorname{sim}$
(2) nào
(9) nao sabe
b) febre
(1) $\operatorname{sim}$
(2) nâo
(9) nao sabe
c) corvulsao
(1) $\operatorname{sim}$
(2) nao
(9) nao sabe
d) problema mentalemocional
(1) $\operatorname{sim}$
(2) nao
(9) nao sabe
e) pressao alta
(1) $\operatorname{sim}$
(2) nâo
(9) nao sabe
f) internaçao qualquer motivo
(1) $\operatorname{sim}$
(2) nào
(9) nao sabe

\section{BLOCO IILOUTRAS INFORMACOES E ACESSO AOS SERVICOS DE SAÚDE}

34. QUAL O PESO DE (NOME CRIANÇA) AO NASCER: gramas

(9999) nao sabe/nao lembra

33.a. sangr

33.b. febr

33.c. conv

33.d. mental

33.e. press

33.f. interge

35. QUAL O COMPRIMENTO (NOME CRIANCA) AO NASCER: $\mathrm{cm}$

(999) nao sabe/nao lembra

36. $\rightarrow$ COLETAR NO CARTAO (DA CRIANÇA OU DA MATERNIDADE):

a. Peso ao nascer (gramas)

b. Comprimento $\longrightarrow(\mathrm{cm})$

c. Idade gestacional semanas

88 - nao tem cartao

37. PREENCHA O QUADRO ABAIXO, CONFORME O CARTÃO DA CRIANCA

Entrevistador: Marque com um $X$ os espacos referentes as vacinas recebidas.

\begin{tabular}{|c|c|c|c|c|c|}
\hline \multirow[t]{2}{*}{ Vacina } & \multicolumn{3}{|c|}{ Datas das vacinas } & \multirow[t]{2}{*}{ reforço } & \multirow[t]{2}{*}{$\begin{array}{c}\text { n. }{ }^{\circ} \text { de doses de } \\
\text { campanha }\end{array}$} \\
\hline & $1^{\prime}$ dose & $2^{a}$ dose & $3^{2}$ dose & & \\
\hline a. TRIPLICE VIRAL & & & & & \\
\hline $\begin{array}{l}\text { b. DTP-Triplice } \\
\text { Bacteriana }\end{array}$ & & & & & \\
\hline c. TETRA (DTP + HIb) & & & & & \\
\hline d. VOP-SABIN & & & & & \\
\hline$\theta$. Rotavírus & & & & & \\
\hline f. BCG & & & & & \\
\hline g. VHB (hepatite B) & & & & & \\
\hline h. VFA (Febre amarela) & & & & & \\
\hline
\end{tabular}

38. (NOME DA CRIANÇA) FEZ USO DE ALGUMA VITAMINA OU FORTIFICANTE NOS ÚLTIMOS 30 DIAS?

(1) $\operatorname{sim}$ (qual?

(2) nao

(9) nao sabe / nao lembra

34. PNref

35. comre

36.a. PN

36.b. comp

36.c. idgest

37.a. tripvir

37.b. DTP

37.c. tetra

37.d. sabin

37.e. rotav

37.f. BCG

37.g.VHB

37.h. VFA

Códigos:

(1) Completo

(2) Incompleto

(3) Nao fomou

(8) Näo tem cartào

38. vitam

39. (NOME DA CRIANÇA) FEZ USO DE ALGUM REMÉDIO PARA VERME NOS ÚLTIMOS 6 MESES?

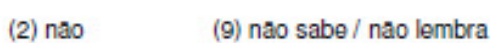

39. reverme

40. (NOME DA CRIANÇA) ELIMINOU VERME APÓS O USO DO REMÉdIO?
(1) $\operatorname{sim}$
(2) nào
(9) nào sabe/ nåo lembra
(8) nsa
40. eliver 
41. (NOME DA CRIANÇA) ESTÁ INSCRITA EM ALGUM DOS PROGRAMAS DE DISTRIBUIÇÃO DE ALIMENTOS OU ALGUM OUTRO PROGRAMA?
a) Programa Erradicaçao Trabalho Infantil
(1) $\operatorname{sim}$
(2) nao
(9) nao sabe
b) Pastoral da criança
(1) $\mathrm{sim}$
(2) nao
(9) nao sabe
c) Bolsa familia
(1) $\operatorname{sim}$
(2) nao
(9) nao sabe

\section{BLOCO IV - MORBIDADES}

42. (NOME DA CRIANÇA) JÁ ESTEVE INTERNADA ALGUMA VEZ?

$\begin{array}{ll}\text { (1) } \operatorname{sim}(2) \text { nao (passe para a questäo 44) } & \text { (9) nâo sabe/nao informa }\end{array}$

43. SE SIM, INDICAR A CAUSA DA INTERNAÇĀO, O PERIODO DE INTERNAÇĀO, O ANO E O LOCAL ONDE A CRIANCA FICOU INTERNADA (HOSPITAL E CIDADE) PARA CADA UMA DAS INTERNACOOES:

1. motivo:

2. periodo (número de dias de internaçáa)

3. ano em que foi internada:

4. nome hospital:

5. cidade:

1. motivo

2. periodo (dias):

3. ano:

4. nome hospital

5. cidade:

1. motivo:

2. periodo (dias):

3. ano:

4. nome hospital:

5. cidade

\section{MORBIDADE NOS ÚLTIMOS 15 DIAS}

44. (Nome da criança) teve algum destes problemas de saúde nos últimos 15 dias?
a) diarréia
(1) sim
(2) nao
(9) nao sabe/nao lembra
b) duraçāo da diarréia dias
(1) sim
(2) nao
(9) nao sabe/nao lembra
c) sangue nas fezes
(1) sim
(2) nao
(9) nao sabe/nao lembra
d) febre
(1) sim
(2) nao
(9) nao sabe/nao lembra
e) vômitos
(1) sim
(2) nao
(9) nao sabe/nao lembra
f) chiado no peito
(1) $\operatorname{sim} \quad$ (2) nao
(9) nao sabe/nao lembra
g) coriza
(1) sim
(2) nao
(9) nao sabe/nao lembra
h) tosse seca
(1) $\operatorname{sim}$
(2) nao
(9) nao sabe/nao lembra
i) tosse com catarro claro
(1) $\operatorname{sim}$
(2) nao
(9) nao sabe/naio lembra
j) tosse com catarro esverdeado
(1) $\operatorname{sim}$
(2) nao
(9) nao sabe/naio lembra
k) tosse com catarro sanguinolento
(1) sim (2) nao
(9) nao sabe/nao lembra
I) perda de apetite
(1) sim (2) nao
(9) nao sabe/nao lembra
m) eliminaçâo de vermes
(1) sim
(2) nào
(9) nao sabe/nao lembra
n) abatimento/tristeza
(1) $\operatorname{sim}$
(2) nao
(9) nao sabe/náo lembra

41.a. peti

41.b. pascri

41.c. bolsa

42. inter 1

43.1. motint 1

43.2. perint 1

43.3. ano 1

43.4. cidint 1

43.5. motint 2

43.6. perint2

43.7. ano2

43.8. cidint 2

43.9. motint3

43.10. perint3

43.11. ano 3

43.12 cidint 3

44. a. diarr

44. b. dudiar

44.c. sanfe

44.d.febre

44.e.vomit

44.f. chipe

44.g. coriz

44.h. tosse

44.i. tocac

44.j.tocae

44.k. tocas

44.I. peape

44.m. verme

44.n.abati

44.o. ouvid 


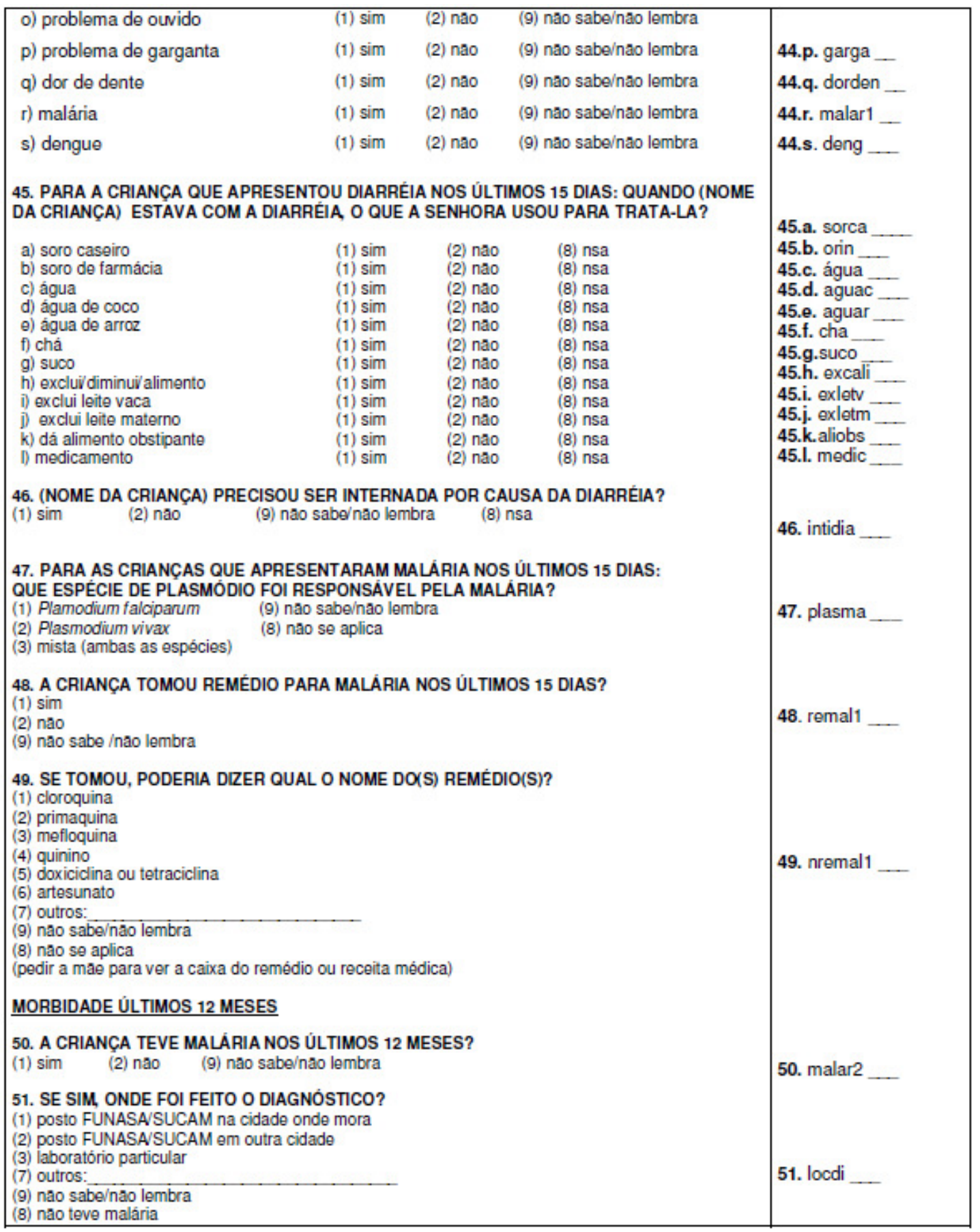




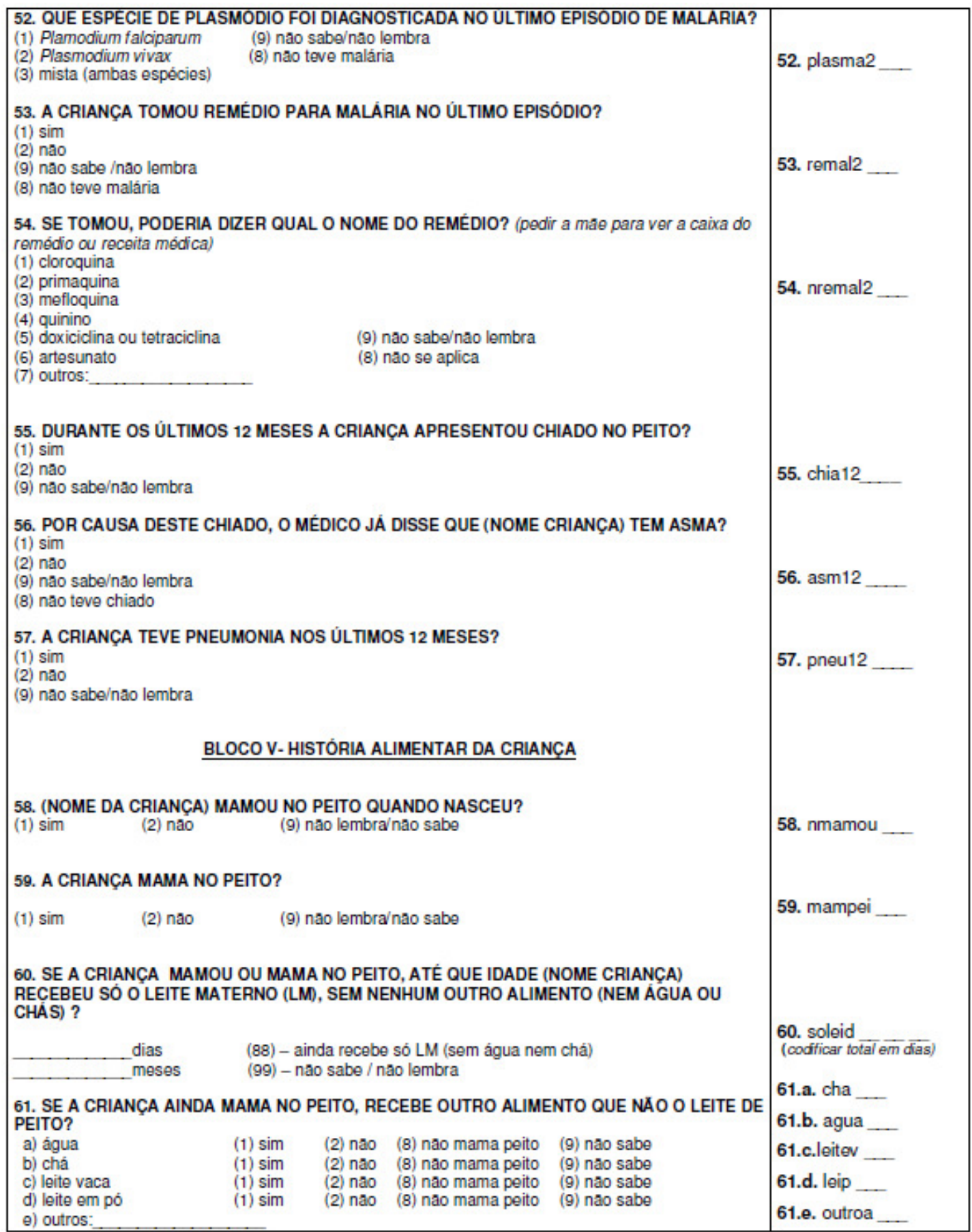


62. COM QUE IDADE (NOME DA CRIANÇA) RECEBEU OUTRO TIPO DE LEITE DIFERENTE DO LEITE MATERNO?

$\begin{array}{lc}\text { C._. dias } & (999) \text { nao lembra / nao sabe } \\ \text { meses } & \text { (888) ainda nao recebeu }\end{array}$

63. COM QUE IDADE (NOME DA CRIANÇA) DEIXOU DE RECEBER O LEITE MATERNO?

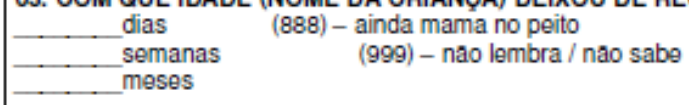

64. A CRIANÇA FEZ USO DA MAMADEIRA?

$\begin{array}{llll}\text { (1) } \mathrm{sim} & \text { (2) nao (passe para questao 68) } & \text { (9) nao lembra/nao sabe }\end{array}$

65. SE FEZ USO DE MAMADEIRA, COM QUAL IDADE INICOU O USO? ____ meses

66. CONTINUA USANDO A MAMADEIRA ? (1) $\operatorname{sim} \quad$ (2) nao

67. QUAL A IDADE QUE DEIXOU DE USAR ? ___ meses ___ anos

68. COM QUE IDADE A CRIANÇA INICIOU A ALIMENTAÇÃO PASTOSA (papas, frutas amassadas)?

meses _._. anos (8) ainda só recebe leite/liquidos

69. COM QUE IDADE A CRIANÇA INICIOU A ALIMENTAÇÁO SÓLIDA (comida de panela)? meses anos

(8) ainda só recebe leite/liquidos

62. leitd

(codificar total em dias)

63. ideld

(codificar total $\overline{e m}$

dias)

64. fezma

65. idama

66. contma

67. idadei

68. past

69. soli

70.1. leite

70.2. feijao

70.3. verdu

70.4. legume

70.5. fruta

70.6. suco

70.7. carne

70.8. peixe

70.9. ovo 


\section{BLOCO VI-ATIVIDADES FISICAS HABITUAIS \\ (Apenas para crianças com idade igual ou acima de 4 anos)}

71. SUA CRIANCA PRATICOU ESPORTES OU EXERCICIOS FISICOS (FUTEBOL, VÓLEI, BASQUETE, NATACCAO, GINÁSTICA, JUDÓ, OUTROS) NOS UULTIMOS 12 MESES?

(1) nao (passe para a questå̀o 74)

(2) $\operatorname{sim}$

72. Quanto tempo gastou por dia nessas atividades? horas

min

73. Quantas vezes por semana praticou esta atividade? vezes por semana

71. pratesp

72. tesp

73. vesp

74. SUA CRIANCA BRINCA NA RUA?

(1) nao (passe para a questảo 78)

(2) sim.

75. Quais brincadeiras säo mais freqüentes?

76. Quanto tempo gasta por dia nessas atividades? horas min

77. Quantas vezes por semana pratica estas atividades? vezes por semana

78. SUA CRIANÇA PARTICIPA DE AULAS DE EDUCAÇĀO FISICA NA ESCOLA?

(1) $\operatorname{sim}$

(2) nato

(8) dispensado

79. SE SUA CRIANCA COSTUMA IR DE BICICLETA OU A PÉ PARA AS ATIVIDADES ABAIXO, QUANTO TEMPO ELA GASTA EM CADA VEZ E QUANTAS VEZES POR SEMANA ELA FAZ ESTAS ATIVIDADES?

\begin{tabular}{||l|c|c|}
\hline Atividade & $\begin{array}{c}\text { Tempo total em minutos } \\
\text { (somar ida e volta) }\end{array}$ & $\begin{array}{c}\text { Vezes por } \\
\text { semana }\end{array}$ \\
\hline (a) Para a escola & & \\
\hline (b) para o clube/quadra & & \\
\hline (c) para cursos em geral, outras atividades & & \\
\hline
\end{tabular}

80. AGORA VAMOS PERGUNTAR QUANTO TEMPO E QUANTAS VEZES POR SEMANA SUA CRIANÇA GASTA NAS SEGUINTES ATIVIDADES:

\begin{tabular}{||l|l|l|}
\hline Atividade & Horas por dia & $\begin{array}{c}\text { Vezes por } \\
\text { semana }\end{array}$ \\
\hline (a) assistir TV durante a semana & & \\
\hline (b) assistir TV no final de semana (Sábado + Domingo) & & \\
\hline (c) jogar video-game & & \\
\hline
\end{tabular}

74. brinrua

75. brinca

76. tbrinca

77. vbrinca

78. edufis

79a. tesc

$79 b$. tclube

79c. tcursos

80a. tvsem 80 b. tvfim 80c. vgame 


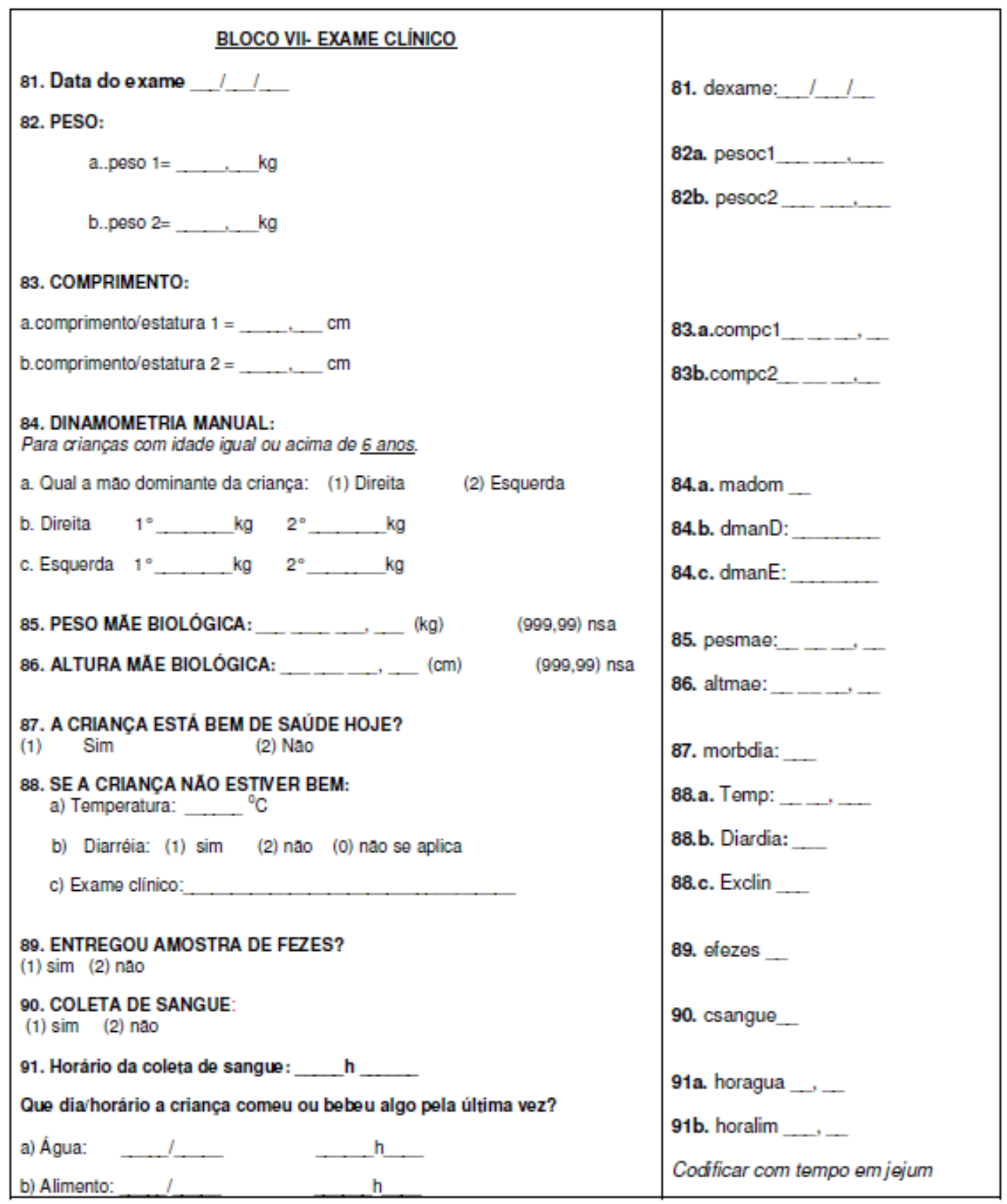


ANEXO 3: Histórico alimentar

\section{INQUERRITO DE CONSUMO ALIMENTAR}

IDENTIFICACCÃO DO DOMÍCLIO INÍCIO (Hs) : / TÉRMINO:

NÚMERO DOMICÍLIO:

NOME DA MÃE:

NOME DA CRIANÇA:

NÚMERO DA CRIANÇA:

ENDEREÇO

COMPLETO:

ENTREVISTADOR:

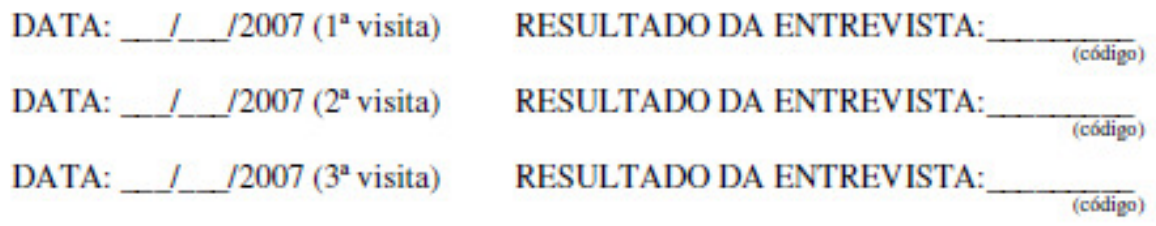

CÓDIGOS

01 - ENTREVISTA COMPLETA

02 - ENTREVISTA INCOMPLETA

03 - MORADORES AUSENTES

04 - ADIADA

05 - RECUSA TOTAL

06 - DOMICÍlLIO DESOCUPADO

77 - OUTRA

(especificar)

REVISADO PELO ENTREVISTADOR? ( ) SIM ( )NÃO

Assinatura do enlavistador

REVISADO PELO SUPERVISOR? ( ) SIM ( )NÃO

Assinatura do supervisor

QUANTAS PESSOAS NORMALMENTE FAZEM AS SEGUINTES REFEIÇÓES NESTA CASA?

CAFÉ DA MANHÃ________PESSOAS

ALMOCO PESSOAS

JANTAR PESSOAS 
HISTÓRICO ALIMENTAR: CONSUMO HABITUAL DA CRIANÇA

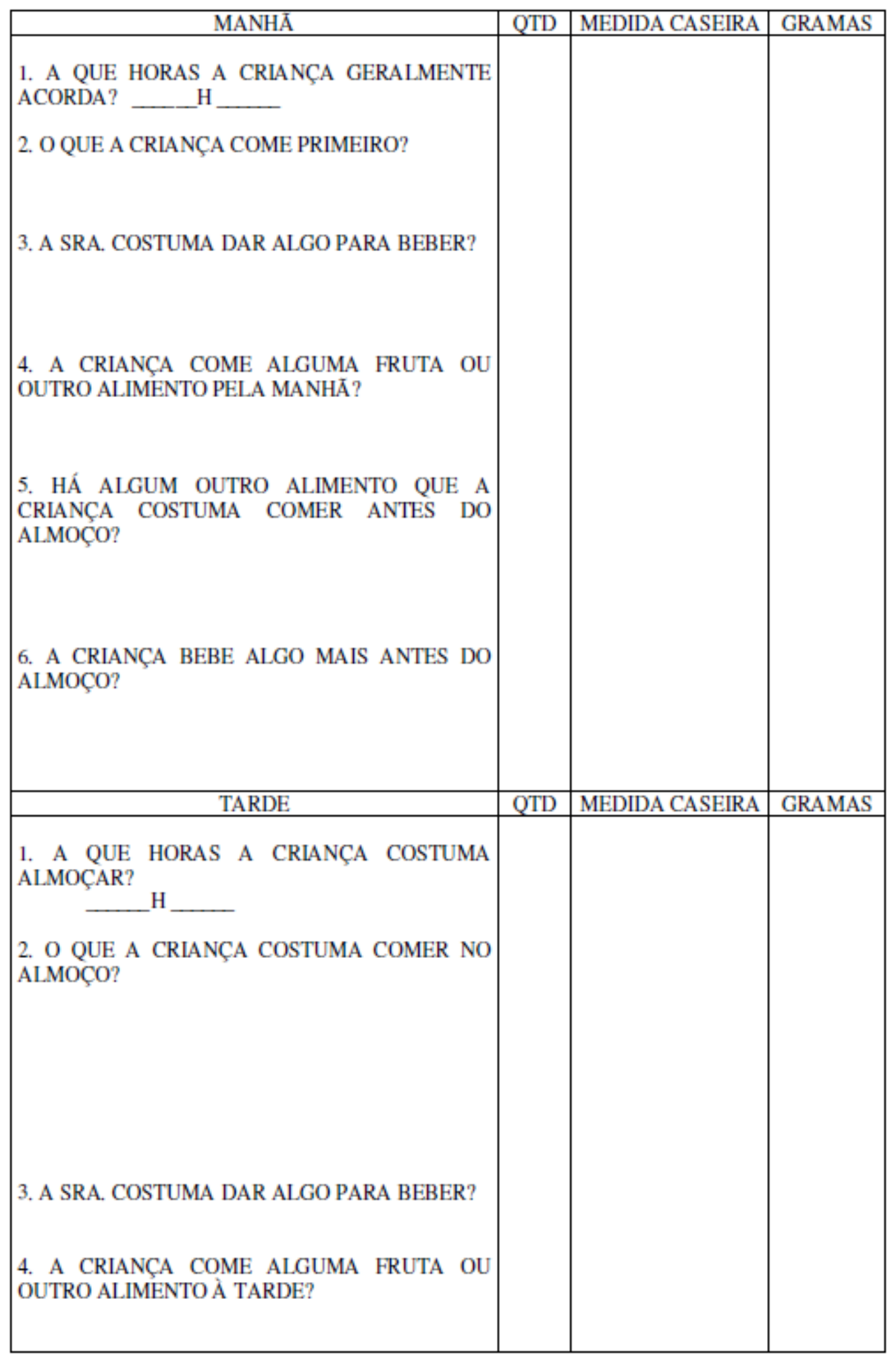


5. HÁ ALGUM OUTRO ALIMENTO QUE A CRIANÇA COSTUMA COMER ANTES DO JANTAR?

6. A CRIANÇA BEBE ALGO MAIS ANTES DO JANTAR?

1. A QUE HORAS A CRIANÇA COSTUMA JANTAR?

$\mathrm{H}$

2. O QUE A CRIANÇA COSTUMA COMER NO JANTAR?

3. A SRA. COSTUMA DAR ALGO PARA BEBER?

4. A CRIANÇA COME ALGUMA FRUTA OU OUTRO ALIMENTO APÓS O JANTAR?

5. HÁ ALGUM OUTRO ALIMENTO QUE A CRIANÇA COSTUMA COMER ANTES DE DORMIR?

6. A CRIANÇA BEBE ALGo MAIS ANTES DE DORMIR?

7. A CRIANÇA COME/BEBE ALGO MAIS DURANTE A NOITE? 


\section{RECEITAS DAS PREPARACÕES}

PREPARAÇÃO:

\begin{tabular}{l|l|l|}
\hline ALIMENTO & MEDIDA CASEIRA & QUANT (G OU ML) \\
\hline & & \\
& & \\
VOLUME/PESO FINAL DA PREPARAÇÃO: PESO DE UMA PORÇÃO: \\
NÚMERO DE PORÇOES:
\end{tabular}

PREPARAÇÃO:

\begin{tabular}{|l|l|l|}
\hline ALIMENTO & MEDIDA CASEIRA & QUANT (G OU ML) \\
\hline & & \\
& & \\
& & \\
\hline
\end{tabular}

VOLUME/PESO FINAL DA PREPARAÇÃO:

NÚMERO DE PORÇOES:

PESO DE UMA PORÇÃO:

PREPARAÇÃO:

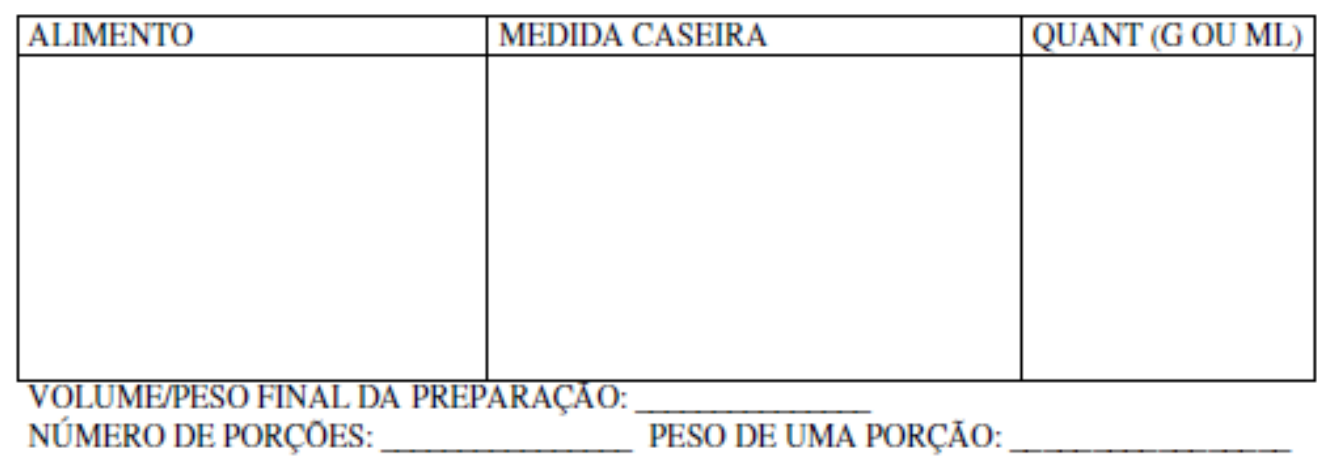


ANEXO 4: Termo de Consentimento Livre e Esclarecido

TERMO DE CONSENTIMENTO LIVRE E ESCLARECIDO

\section{PROJETO DE PESQUISA : CONDIÇÕES DE SAÚDE E NUTRIÇÃO DE CRIANÇAS DA AMAZÔNIA OCIDENTAL BRASILEIRA .}

Durante a leitura do documento abaixo fui informado que posso interromper para fazer qualquer pergunta, com o objetivo de tirar dúvidas e o meu melhor esclarecimento.

$\mathrm{Eu}$, com _ anos de idade fui procurado(a) por um membro da equipe de pesquisa coordenada pelo professor Dr. Pascoal Torres Muniz, quando fui informado(a) sobre o objetivo da pesquisa com o título acima citado. $\mathrm{O}$ objetivo principal dessa pesquisa é avaliar o estado de saúde e nutrição de crianças menores de 5 anos. Foi explicado que as crianças anêmicas e/ou com parasitas intestinais receberăo tratamento sob onientação médica da equipe de pesquisa.

O Dr. Pascoal, ou membro da sua equipe, também leu este documento e esclareceu os seus termos, bem como deixou claro que se desejar tenho o direito de saber o resultado desta pesquisa. Segundo as informaçôes prestadas, a pesquisa consta de levantamento de dados raciais e de saúde dos meus filhos menores de 5 anos de idade. Ficou claro que caso não aceite participar desta pesquisa, não terei qualquer prejuízo.

$\mathrm{Na}$ apresentação do pesquisador foi dito também que todas as informaçōes a serem prestadas sobre a minha pessoa e de familia serão mantidas em sigilo e não poderei ser, identificada como participante da pesquisa.

Assim considero-me satisfeito com as explicaçøes do pesquisador e concordo em participar como voluntário(a) deste estudo. COMO TENHO DIFICULDADE PARA LER ( SIM ( ) NÃO( ) ), O ESCRITO ACIMA, ATESTO TAMBÉM QUE O DR. PASCOAL (OU MEMBRO DA SUA EQUIPE) LEU PAUSADAMENTE ESSE DOCUMENTO E ESCLARECEU AS MINHAS DÚVIDAS, E COMO TEM A MINHA CONCORDÂNCIA PARA PARTICIPAR DO ESTUDO, COLOQUEI ABAIXO A MINHA ASSINATURA ( OU IMPRESSÃO DIGITAL).

Rio Branco- Acre, __ de de 2007.

\section{Pesquisado:}

Nome:

Assinatura 
IMPRESSÃO DATILOSCÓPICA ( quando se aplicar)

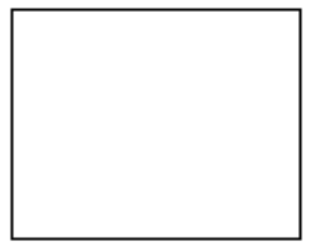

Testemunhas:

1. Nome:

Assinatura:

2. Nome:

Assinatura:

Marly Augusto Cardoso

ou Membro da Equipe

Documento em duas (2) vias, uma para ser entregue a pessoa (ou responsável) que vai participar da pesquisa. 


\section{ANEXO 5: Aprovação do Comitê de Ética em Pesquisa da FSP/USP}

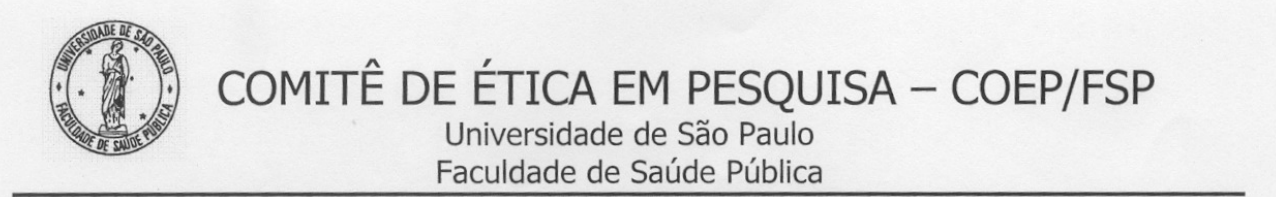

Of.COEP/ 149 /07

Protocolo

Projeto de Pesquisa

Pesquisador(a)
1681

SAÚDE E NUTRIÇÃO DE CRIANÇAS PRÉ-ESCOLARES DA AMAZÔNIA OCIDENTAL BRASILEIRA: UM ESTUDO DE COORTE

MARLY AUGUSTO CARDOSO

07 de agosto de 2007.

Prezado(a) Orientador(a),

O Comitê de Ética em Pesquisa da Faculdade de Saúde Pública da Universidade de São Paulo - COEP analisou, em sua 6. a/07 Sessão Ordinária, realizada em 03/08/2007, de acordo com os requisitos da Resolução CNS/196/96 e suas complementares, o protocolo de pesquisa acima intitulado, e o considerou APROVADO.

Lembramos, ainda, que conforme Resolução CNS/196/96 são deveres do(a) pesquisador(a):

1. Comunicar, de imediato, qualquer alteração no projeto e aguardar manifestação deste CEP (Comitê de Ética em Pesquisa), para dar continuidade à pesquisa;

2. Manter sob sua guarda e em local seguro, pelo prazo de 5 (cinco) anos, os dados da pesquisa, contendo fichas individuais e todos os demais documentos recomendados pelo CEP, no caso eventual auditoria;

3. Comunicar, formalmente a este Comitê, quando do encerramento deste projeto;

4. Elaborar e apresentar relatórios parciais e finais;

5. Justificar, perante o CEP, interrupção do projeto ou a não publicação dos resultados.

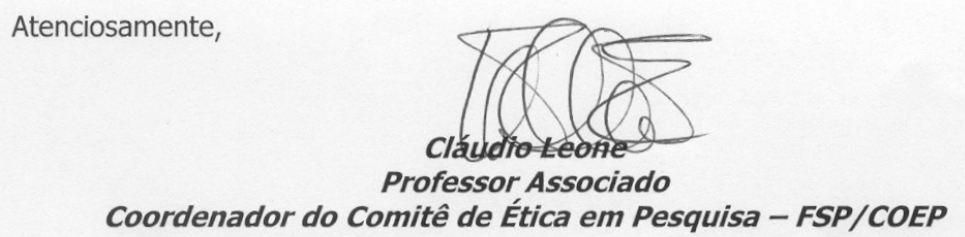

Ilm. a Sr.a

Prof.a Dr.a MARLY AUGUSTO CARDOSO

Departamento de NUTRIÇÃO 
ANEXO 6: Arquivo fotográfico

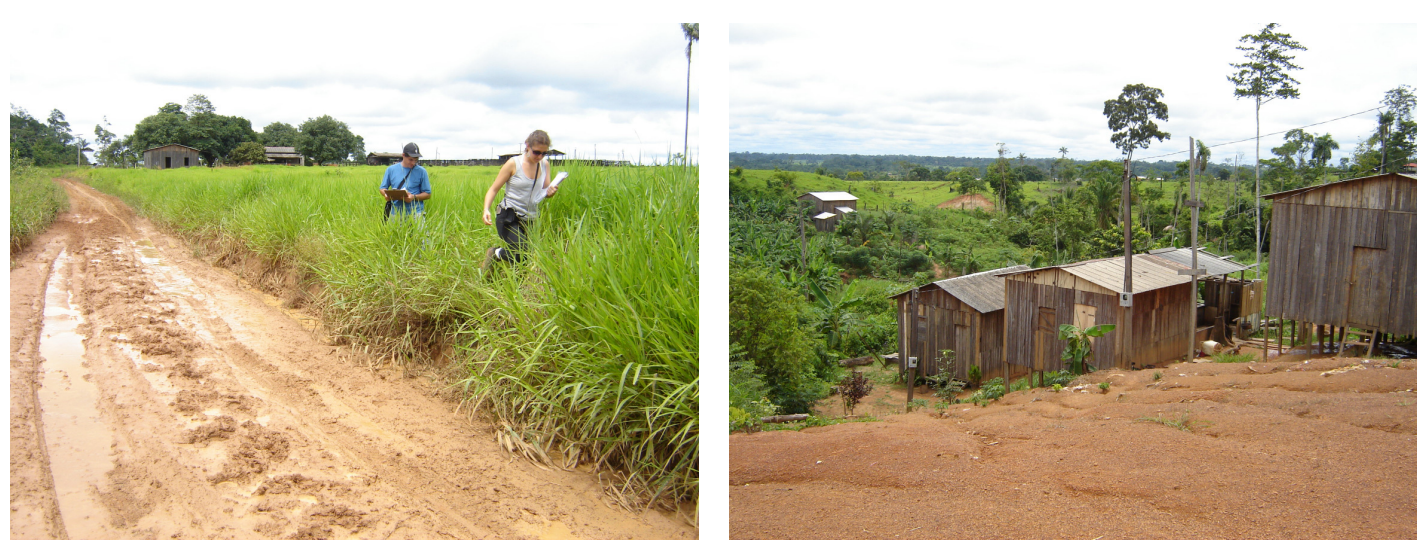

Visitas domiciliares
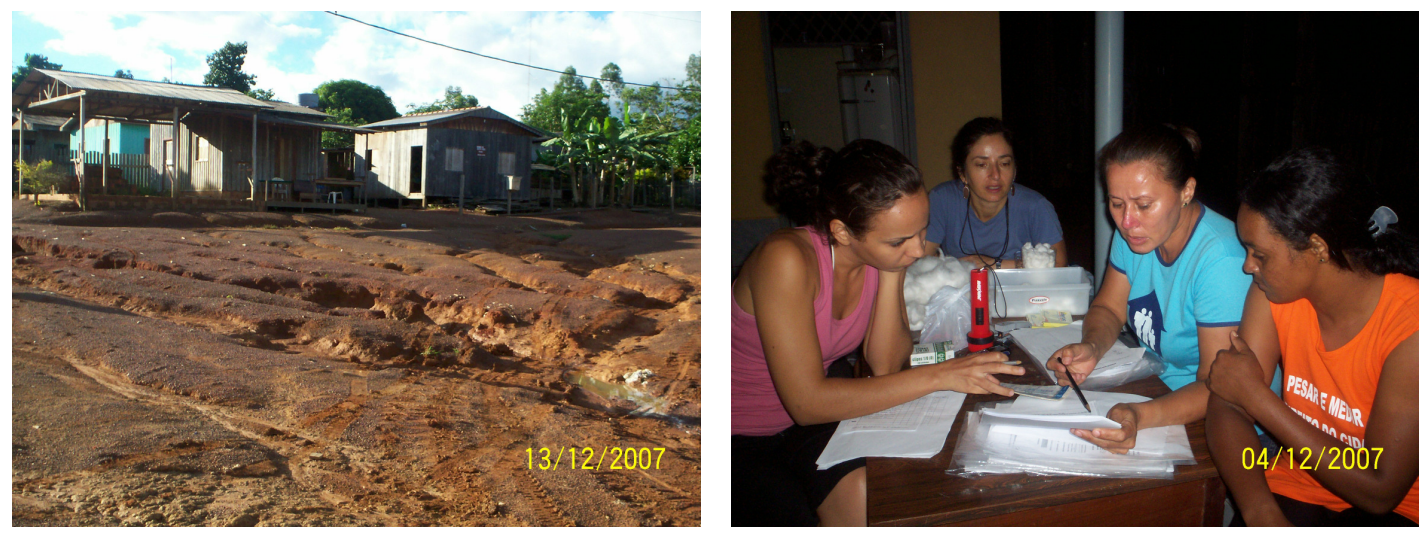

Visitas domiciliares

Supervisão com os ACS
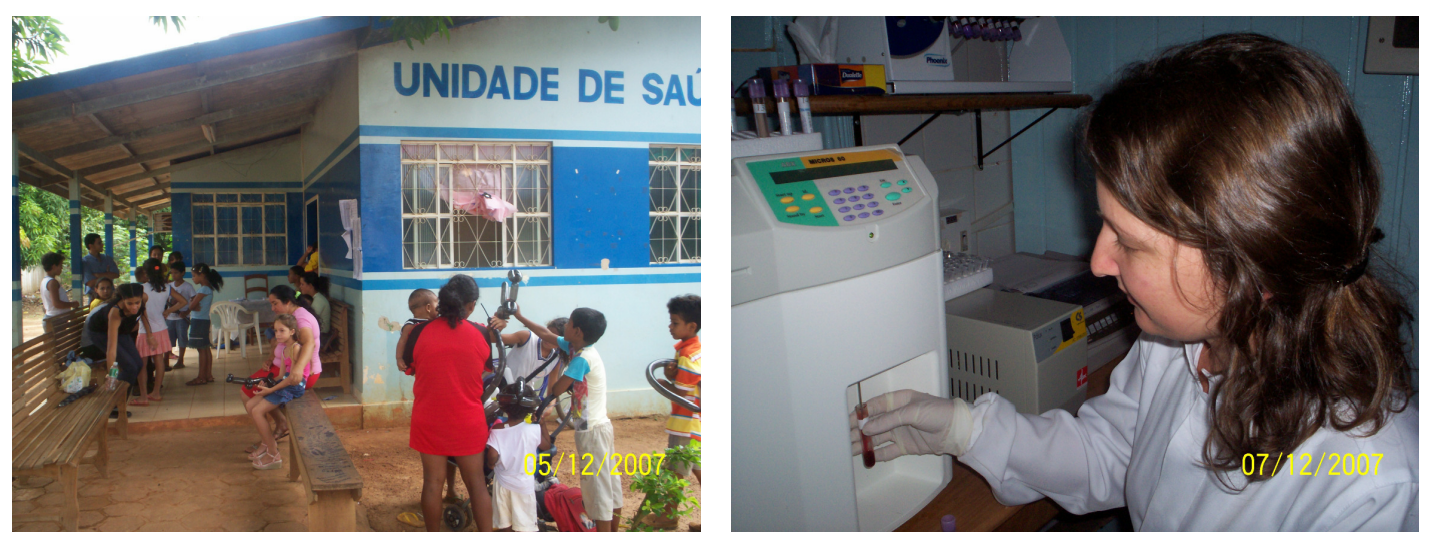

Unidade de Saúde

Laboratório instalado em Acrelândia 

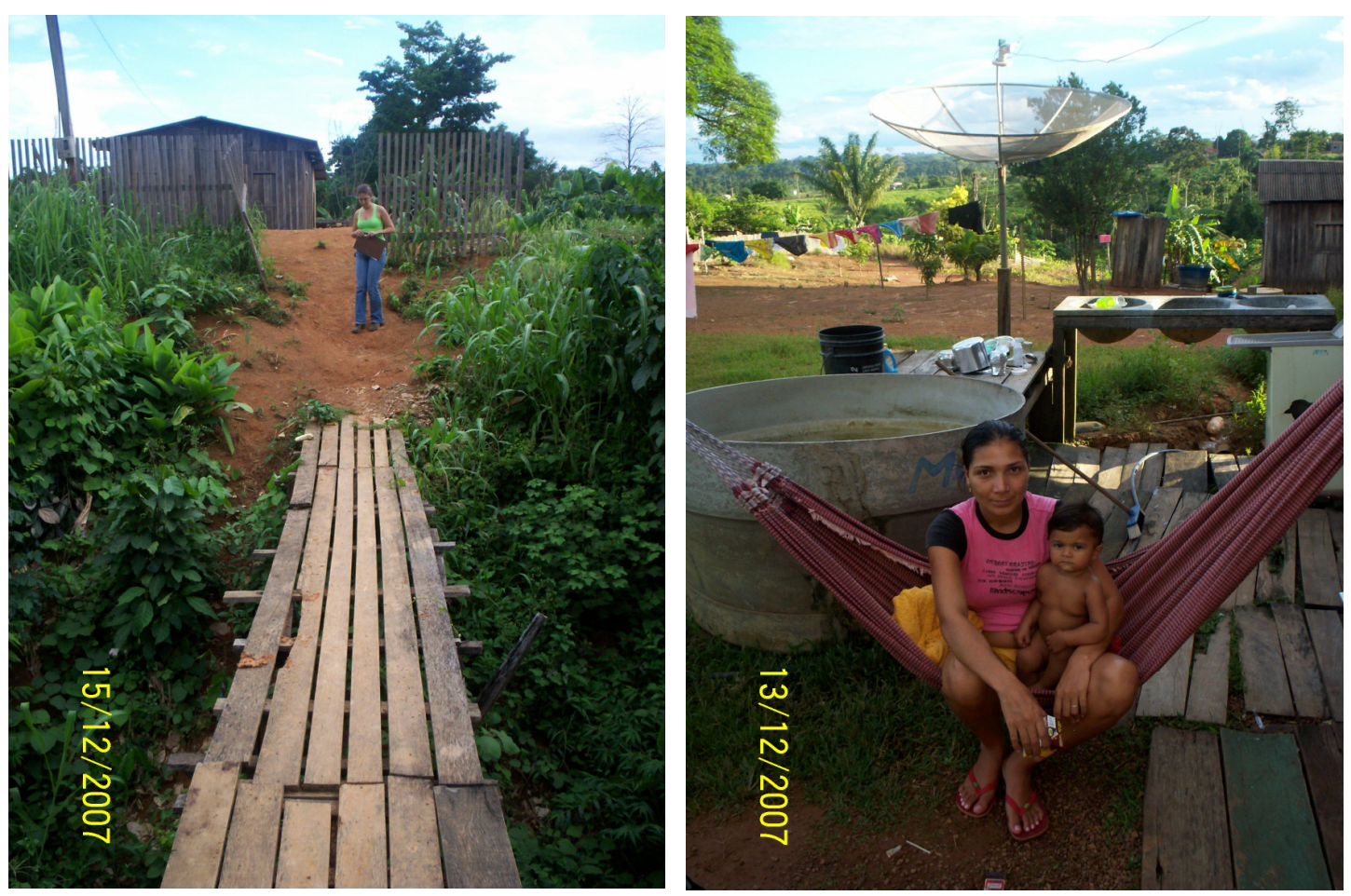

Visitas domiciliares
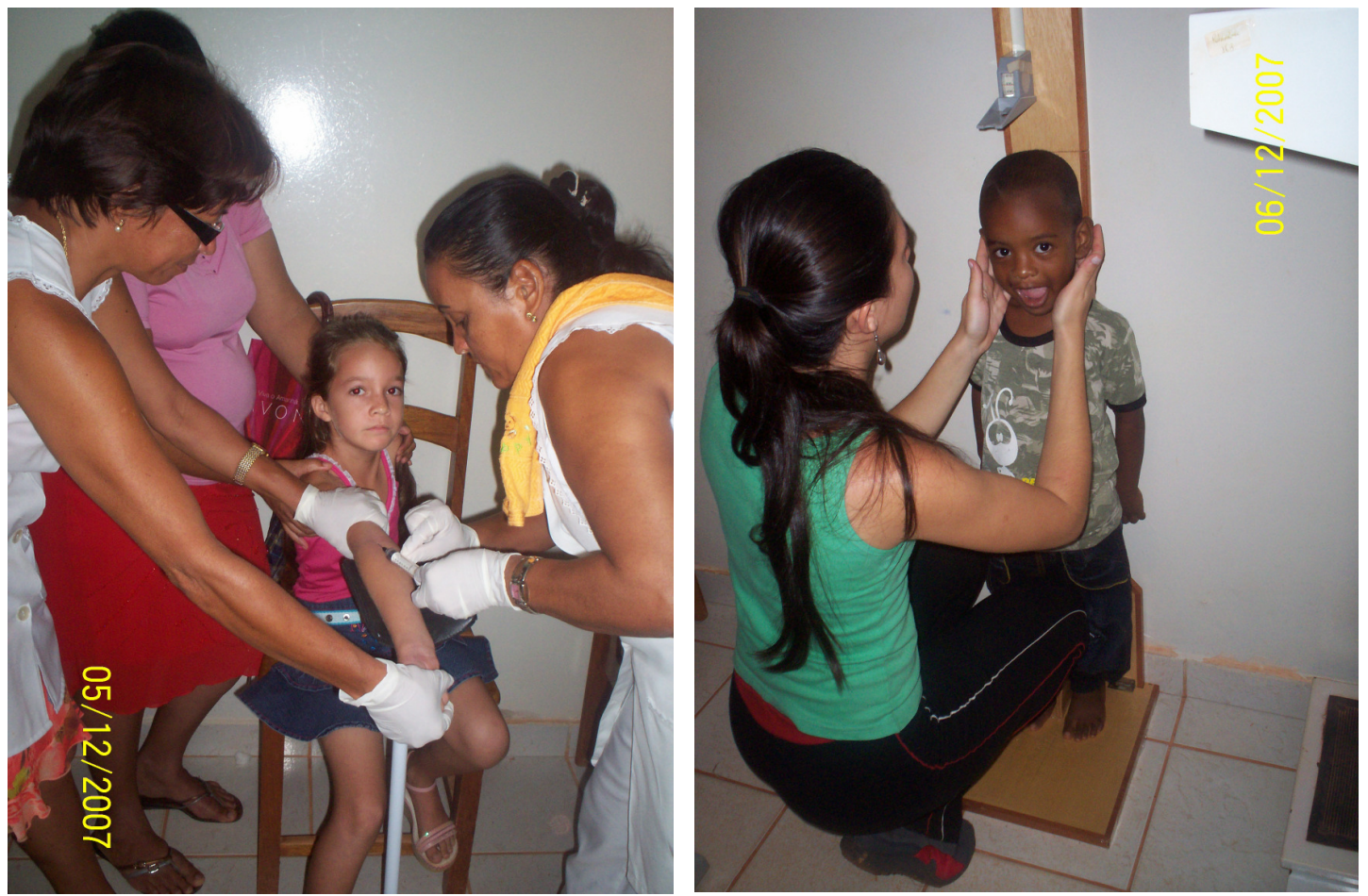

Exames bioquímicos

Avaliação antropométrica 